UNIVERSIDADE FEDERAL DE JUIZ DE FORA

FACULDADE DE LETRAS

PROGRAMA DE PÓS-GRADUAÇÃO EM LETRAS: ESTUDOS LITERÁRIOS

LUANA MARTINS DE ARRUDA

A LOUCURA COMO FORMA DE PENSAR A REALIDADE FEMININA:

A OBRA DE MAURA LOPES CANÇADO 


\title{
A LOUCURA COMO FORMA DE PENSAR A REALIDADE FEMININA: A OBRA DE MAURA LOPES CANÇADO
}

\author{
Dissertação apresentada ao Programa de Pós- \\ graduação em Letras: Estudos Literários, da \\ Universidade Federal de Juiz de Fora, como \\ requisito parcial para a obtenção do título de \\ Mestre em Letras, Área de concentração: \\ Teorias da literatura e representações culturais. \\ Linha de Pesquisa: Literatura e Crítica \\ Literária. \\ Orientadora: Prof.a Dra. Nícea Helena de \\ Almeida Nogueira
}


Ficha catalográfica elaborada através do programa de geraçāo automática da Biblioteca Universitária da UFJF, com os dados fornecidos pelo(a) autor(a)

Arruda, Luana Martins de.

A loucura como forma de pensar a realidade feminina : a obra de Maura Lopes Cançado / Luana Martins de Arruda. -- 2021. $110 \mathrm{f}$.

Orientadora: Nicea Helena de Almeida Nogueira

Dissertação (mestrado acadêmico) - Universidade Federal de Juiz de Fora, Faculdade de Letras. Programa de Pós-Graduação em Estudos Literários, 2021.

1. Maura Lopes Cançado. 2. Hospício é Deus. 3. Escrita de si. 4. Literatura e Loucura. 5. Escrita etnográfica. I. Nogueira, Nícea Helena de Almeida, orient. II. Titulo. 


\section{A LOUCURA COMO FORMA DE PENSAR A REALIDADE FEMININA: A OBRA DE MAURA LOPES CANÇADO}

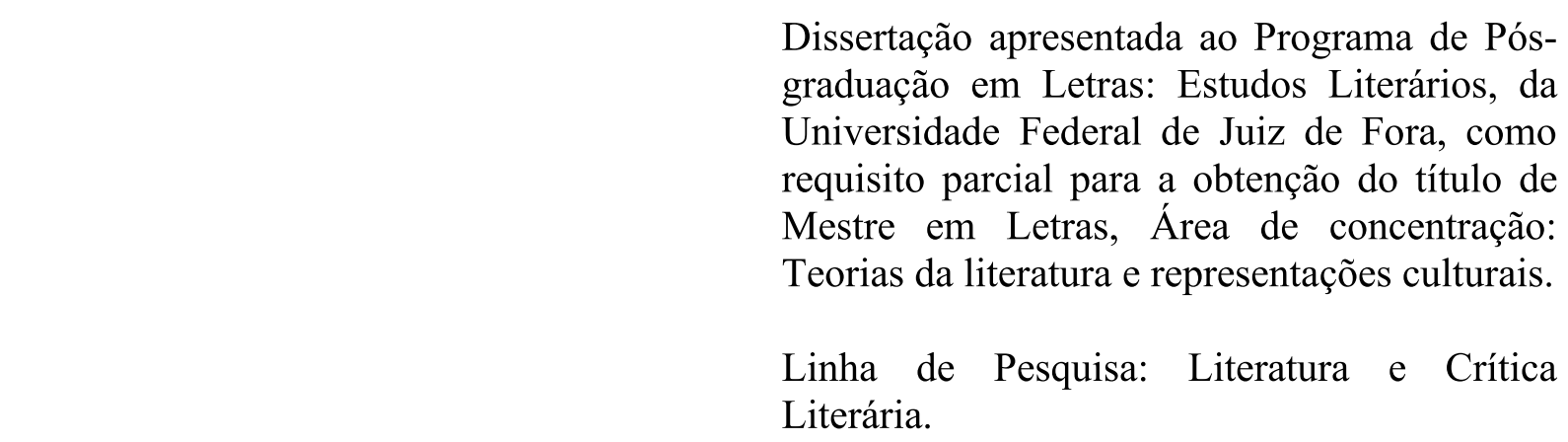

Aprovada em:

BANCA EXAMINADORA

Prof. ${ }^{a}$ Dra. Nícea Helena de Almeida Nogueira - Orientadora

Universidade Federal de Juiz de Fora

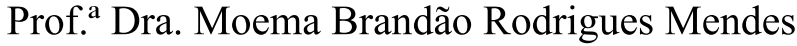

Centro Universitário UniAcademia

(membro titular externo)

Prof. Dr. Humberto Fois Braga

Universidade Federal de Juiz de Fora

(membro titular interno) 


\section{AGRADECIMENTOS}

A Deus, pela energia do amor maior.

À minha família: meus pais Ana e Daniel, meus irmãos Letícia e Pedro, e minha tia Lucia Helena, sou eternamente grata pelo apoio incondicional.

À Professora Dra. Nícea Helena, orientadora desta pesquisa, pela disposição, pela generosidade e pela confiança no meu trabalho, enriquecendo-me com seus ensinamentos, muito obrigada.

Ao Professor Dr. Humberto Fois, pelas valiosas contribuições na banca de qualificação. Obrigada pelas reflexões e sugestões nos estudos da antropologia, as quais foram muito importantes para a conclusão desta pesquisa.

À Professora Dra. Moema Brandão, meu agradecimento e admiração. Obrigada por seu interesse e disponibilidade em ler este trabalho.

Aos demais professores que aceitaram o convite e integraram a minha banca de defesa, meus sinceros agradecimentos.

Aos professores e colegas do grupo de pesquisa Travessias e Feminismo(s): estudos identitários na autoria feminina, pela troca de conhecimentos.

A todos os professores e funcionários da FALE e do Programa de Pós-Graduação em Letras Estudos Literários da UFJF, pela inestimável contribuição na minha formação humana, intelectual e profissional.

Aos secretários Caio e Daniele, pela solicitude e gentileza constante.

À UFJF, pelo financiamento desta pesquisa.

Aos amigos que participaram ativamente deste processo, transformando os momentos mais difíceis em apoio, motivação e carinho: Cida Almeida, Marilda Clareth, Patrícia Aniceto, Regiane Souza, Vanessa Vieira e Weber Wagner.

E um agradecimento especial às amigas da faculdade, Isabela Lima, Letícia Campos e Tereza Ferreira, que, cuidadosamente, leram o meu projeto de pesquisa, antes da iniciação no Mestrado. Agradeço pelos preciosos apontamentos.

À querida Agna Farias, por ter me apresentado à Maura.

E, finalmente, agradeço a todos que, de alguma maneira, contribuíram para esta conquista. 
E se em algumas almas humanas, singularmente dotadas e de percepção sensível, se levanta a suspeita de sua composição múltipla, e, como ocorre aos gênios, rompem a ilusão da unidade personalística e percebem que o ser se compõe de uma pluralidade de seres como um feixe de eus, e chegam a exprimir essa ideia, então, imediatamente a maioria as prende, chama a ciência em seu auxílio, diagnostica esquizofrenia e protege a humanidade para que não ouça um grito de verdade dos lábios desses infelizes (HESSE, 2013, p. 72). 


\section{RESUMO}

Esta pesquisa analisa a escrita da autora brasileira Maura Lopes Cançado, nascida em São Gonçalo do Abaeté, Minas Gerais, em 27 de janeiro de 1929. Seu livro, Hospício é Deus, foi produzido entre os anos de 1959 e 1960, quando a autora esteve internada em um hospital psiquiátrico no bairro do Engenho de Dentro, no Rio de Janeiro. A partir desse contexto, e levando em consideração a problemática existencial da loucura, nosso trabalho enfoca, desse modo, a escrita de si e a experiência da loucura expressa no diário intitulado Hospício é Deus, lançado em livro em 1965. Interessa-nos, em particular, a representação da loucura no diário a fim de investigar como a alteração de estados mentais pode ser apresentada na escrita, como ela se relaciona à concepção de memória, diário, autobiografia e ficção sobre o eu, como se constrói enquanto rompimento entre espaço público e privado, e, como ocupa função importante para a construção e afirmação de identidade. Assim, após a apreciação dos temas propostos, buscamos analisar o diário da autora como uma escrita etnográfica, embasando-nos nos estudos da antropologia pós-moderna no século XX.

Palavras-chave: Hospício é Deus. Maura Lopes Cançado. Escrita de si. Literatura e Loucura. Escrita etnográfica. 


\begin{abstract}
This research analyzes the writing of the Brazilian author Maura Lopes Cançado. She was born in São Gonçado do Abaeté, a city of the state of Minas Gerais, Brazil, on January 27th, 1929. Her book, Hospicio é Deus, was written between 1959 and 1960. The author was in a psychiatric hospital in Engenho de Dentro, a neighborhood of Rio de Janeiro, during the book's writing. From this context, and taking into account the existential problem of madness, our work focuses on the self writing and the experience of madness expressed in the diary Hospício é Deus, published as a book in 1965. We are particularly interested in the representation of madness in the diary to investigate how the alteration of the mental state can be presented in writing, how it relates to the concepts of memory, diary, autobiography, and fiction about the self, how it is constructed as a rupture between public and private spaces, and how it plays an essential role in the narrative in the construction and affirmation of identity. Thus, after exploring the proposed themes, we seek to analyze the author's diary as ethnographic writing, basing on post-modern anthropology studies in the 20th century.
\end{abstract}

Keywords: Hospicio é Deus. Maura Lopes Cançado. Self writing. Literature and Madness. Ethnographic writing. 


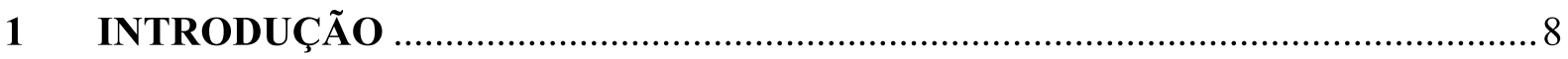

2 MAURA LOPES CANÇADO E A ESCRITA LITERÁRIA ................................. 11

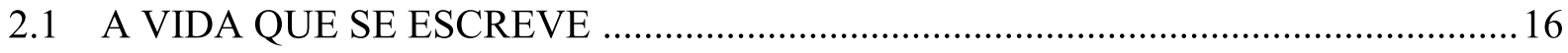

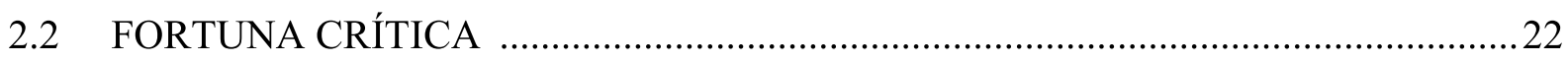

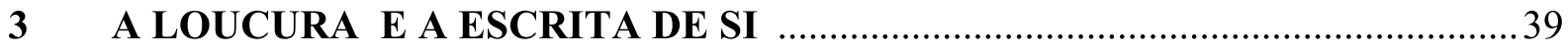

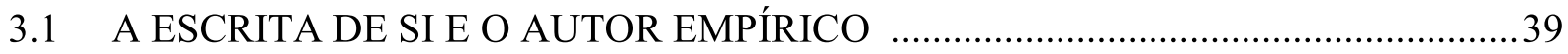

3.2 OS LIMITES ENTRE ARTE E VIDA:

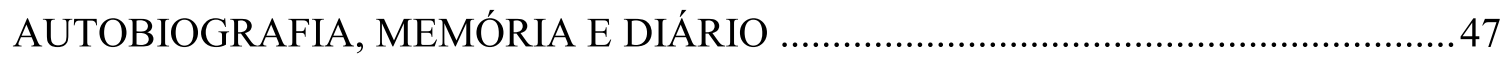

3.3 A LOUCURA COMO FORMA DE NARRAR A EXPERIÊNCIA .............................59

4 DO FAZER LITERÁRIO À ESCRITA ETNOGRÁFICA …................................ 70

4.1 O FAZER LITERÁRIO EM HOSPÍCIO É DEUS …............................................. 71

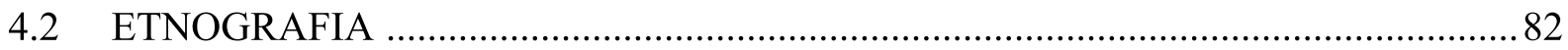

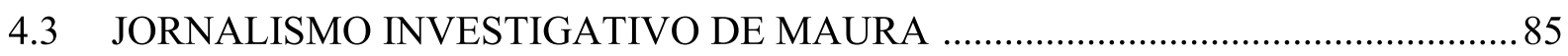

4.4 DIÁRIO DE CAMPO E HOSPÍCIO É DEUS: A ESCRITA E A REPRESENTAÇÃO DA ALTERIDADE ......................................... 90

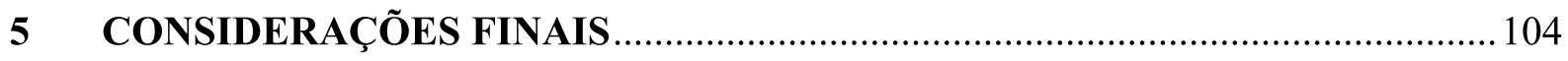

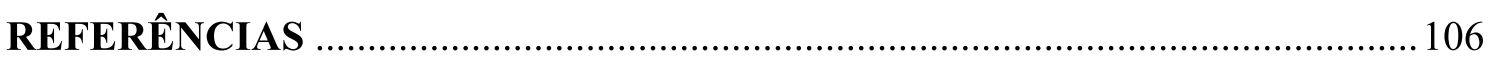




\section{INTRODUÇÃO}

Por que não nos dão a nós, mulheres, o direito de começar? Por que sempre nos apontam o caminho? (CANÇADO, 2016a, p. 116).

Maura Lopes Cançado (1929-1993) é uma escritora brasileira que passou boa parte de sua vida internada em instituições psiquiátricas. Seu mais famoso livro Hospício é DeusDiário I, publicado em 1965, foi escrito durante sua internação no antigo Gustavo Riedel Centro Psiquiátrico Nacional, hoje Instituto Nise da Silveira, no Rio de Janeiro. Entre uma internação e outra, trabalhou no Suplemento Dominical do Jornal do Brasil (1956-1961), ao lado de intelectuais como Reynaldo Jardim, Ferreira Gullar, Assis Brasil e Carlos Heitor Cony. Dessa experiência, nasceram diversos contos que, depois, foram reunidos numa coletânea intitulada $O$ sofredor do ver, publicado em 1968. Assim, tanto a publicação do diário como o livro de contos garantiram-lhe, à época, elogios por parte do público e da crítica literária. Contudo, após a sua morte, no dia 19 de dezembro de 1993 no Rio de Janeiro, suas obras seriam esquecidas, sendo mais tarde reeditadas em 2012 pela Confraria dos Bibliófilos, de Brasília - exclusiva para os sócios -, e pela editora Autêntica, em 2015, e relançadas por esta mesma editora em 2016.

Nesta pesquisa, buscamos estudar o diário intitulado Hospício é Deus, cuja obra nos mostra a escrita de uma mulher que, de forma voluntária, procurou o espaço do manicômio por não conseguir adequar-se às exigências da sociedade patriarcal. Em seu livro, a autora entrelaça temas ligados a loucura, a sociedade de seu tempo e as condições dos tratamentos psiquiátricos, ao mesmo tempo em que especula em torno da relação entre transtorno mental e transgressão feminina a partir de um retorno ao seu passado para compreender os motivos de seu sofrimento psíquico. Maura sofria por não se enquadrar nos padrões sociais, e, diversas vezes, foi impedida de voltar a estudar devido à sua condição de mãe solteira e divorciada.

Sobre a questão do papel destinado à mulher em meados do século XX, nossa análise nos mostrará que o lugar de exclusão social é o traço que caracteriza a vida da autora. Para o entendimento melhor desse momento, baseamo-nos em um breve período histórico, à luz do contexto do Brasil Colônia, reconhecendo que o destino das mulheres foi moldado pelas instituições de poder masculinos, representadas pela Igreja, o Estado e o conhecimento médico existente nessa época. A respeito desse período, a historiadora Mary Del Priore (1990) nos esclarece como o papel da mulher nessa sociedade influenciou hábitos, crenças e comportamentos da mulher na sociedade moderna. Sem dúvida, os discursos normativos que 
insistem em excluir as diferenças, se fizeram predominantes, em particular pela Igreja, que, durante séculos na sociedade Ocidental, empregou valores de comportamentos a serem seguidos. Nessa perspectiva, a mulher que ousasse tomar as rédeas de seu próprio destino seria privada do convívio social, sendo, pois, desqualificada e reprimida. Logo, seria reconhecida como louca. Consequentemente, as dificuldades impostas às mulheres, em razão dessa opressão social e moral, nos fizeram refletir que a loucura feminina frequentemente está relacionada a uma questão de transgressão social do que propriamente uma doença mental. Ou seja, refletir sobre a mulher louca é discutir sobre a representação social da mulher, dos papéis femininos estabelecidos e dos comportamentos que não eram o esperado pela sociedade. Em nossos estudos a história nos mostra que, se desde o início dos tempos o sujeito-louco era colocado à margem, o sujeito-louco mulher cumpria com o seu duplo destino: natureza enferma e sujeição.

Tendo em vista tais considerações, nosso trabalho busca mostrar a escrita de Maura Lopes Cançado à luz da representação da loucura no plano literário, mais, precisamente, na escrita de si. Maura é certamente uma autora que nos permite refletir a respeito da condição feminina e nos dá ferramentas para discutir e analisar as relações entre loucura, subjetividade e memória, ao mesmo tempo em que nos permite explorar essa dimensão do "equilíbrio instável da mente humana, cujo pêndulo oscila entre os concertos e desconcertos da razão" (QUEIROZ, 1990, p. 65). Nesse contexto, dar voz à Maura Lopes Cançado é refletir o conceito de loucura que vem sendo (re)construído ao longo da história, assim como lembrar que, por meio da sua fala, há humanidade por detrás dessa condição que durante muito tempo foi definida como sendo o vazio da existência.

Além desses elementos, ressaltamos ainda a importância de se trabalhar a subjetividade da narradora-personagem, a qual vem ganhando cada vez mais visibilidade no campo das publicações dos estudos acadêmicos. Para tanto, após um embasamento teórico relativo às questões do fazer literário nos domínios da escrita de si, o objetivo desta pesquisa foi desenvolver a seguinte pergunta: Quais são as características narrativas desenvolvidas por Maura Lopes Cançado no livro Hospício é Deus?

Como procuraremos demonstrar, os escritos de Maura nos mostram as inquietações existenciais de uma consciência interior, que nos revela que na escrita é a experiência que direciona a vida. Objetivamente, percebemos que a visão de mundo da escritora é expressa por meio do signo da loucura, um dos recursos frequentemente utilizados para a construção de sua literatura, visto que a condição de louca foi construída em cima de uma vida que a rejeitou 
de inúmeras maneiras, o que acaba por elucidar muitas questões a respeito do conceito de loucura.

Dessa forma, o processo de nossa pesquisa foi organizado da seguinte maneira: buscamos, inicialmente, conhecer a fortuna crítica da autora, a fim de saber quais reflexões foram feitas sobre a narrativa do diário. Em seguida, reunimos textos que tratassem da temática da loucura, da escrita de si, e outros assuntos afins, para que, a partir da leitura e análise da obra literária, pudéssemos estabelecer as seguintes relações: a) o que um texto nos revela sobre quem o escreve, e b) o papel destinado à mulher na sociedade e como esse papel pode estar diretamente relacionado à loucura feminina. Nesse caminho, articulando conceitos de literatura, crítica literária e antropologia, procuramos desenvolver como é construída a narrativa da loucura a partir da escrita do diário.

Assim, o presente estudo é composto de três capítulos. No primeiro, intitulado "Maura Lopes Cançado e a escrita literária”, apresentamos uma possível trajetória biográfica da autora e parte de sua fortuna crítica. Nestes estudos, buscamos conhecer análises desenvolvidas por pesquisadores acerca do processo de criação do diário da autora. Cada leitura nos mostrou um aspecto inerente à composição, ao enredo e à linguagem de Hospício é Deus. No segundo, “A loucura e a escrita de si”, discutimos a relação entre as três instâncias narrativas que compõem o livro de Maura: autobiografia, memória e diário e, refletimos que a mistura entre a realidade $^{1}$ e ficção da autora pode trazer algumas respostas a questões que são formuladas por nossa sociedade: o que é loucura. E, no último capítulo, "Do fazer literário à escrita etnográfica", conferimos a Maura a persona de etnógrafa, por entendermos que ela desempenha no hospício um trabalho de pesquisa, onde ela descreve e caracteriza a estrutura social e política desse espaço. A partir de algumas passagens da obra, mostramos que com os estudos da Antropologia nasce um novo estilo literário, a etnografia.

${ }^{1} \mathrm{O}$ conceito de realidade presente no título desta pesquisa A loucura como forma de pensar a realidade feminina: a obra de Maura Lopes Cançado, parte da compreensão de que por trás de uma consciência individual é possível compreender a realidade a partir de um lugar socialmente determinado pelo gênero. Por isso, é preciso ter presente que, quando Maura descreve sobre as suas experiências de mulher estigmatizada pela sociedade, ela problematiza a dimensão social da loucura feminina. Trata-se, na verdade, de uma escrita que modela e recorta a sua experiência como mulher hospiciada inserida em um contexto traumático coletivo de que sofrem os excluídos, em especial, as mulheres. Assim é que, o universo e a escrita de Maura estão envoltos pela memória construída no espaço do hospício, o que nos permite afirmar que sua escrita transita entre a ficção a e não-ficção, uma vez que a linguagem não é capaz de representar o real, mas parte do real para transformá-la em ficção. Segundo o Dicionário de Teoria da Narrativa de Carlos Reis e Ana Cristina M. Lopes (1988, p. 43), "a ficcionalidade pode ser concebida em termos de intencionalidade" e uma vez admitido isso, concordamos que "o contrato da ficção não exige um corte radical e irreversível com o mundo real" (1988, p. 44). 


\section{MAURA LOPES CANÇADO E A ESCRITA LITERÁRIA}

Considero meu diário simplista. Sou muito mais do que aparenta ser neste diário (CANÇADO, 2016a, p. 197).

Entre o dia 20 de abril e 20 de maio de $1949^{2}$, por conta de uma crise de depressão, Maura Lopes Cançado internou-se, por conta própria, na Casa de Saúde Santa Maria, clínica psiquiátrica particular, em Belo Horizonte. Dez anos depois, deu entrada no hospital Gustavo Riedel, situado no bairro do Engenho de Dentro, na cidade do Rio de Janeiro. Maura escreveu em seu diário:

25-10-1959 [...] Acho-me na seção Tillemont Fontes, Hospital Gustavo Riedel, Centro Psiquiátrico Nacional, Engenho de Dentro, Rio. Vim sozinha. $\mathrm{O}$ que me trouxe foi a necessidade de fugir para algum lugar, aparentemente fora do mundo. (Ou de _ _ _ Era tão grave. Proteção? Mas aqui, onde não me parecem querer bem e sofri tanto?) ("Não me querer bem" talvez seja minha maneira única de ser amada.) Havia lá fora grande incompreensão. Sobretudo pareceu-me estar sozinha. Isto faria rir a muitas pessoas: eu trabalhava no Suplemento Literário do Jornal do Brasil, onde me cercavam de grande atenção e muito carinho. Reynaldo Jardim é o diretor e me queria bem deveras. Ó, o zelo de todos. O zelo de Reynaldo. Naturalmente, penso, por eu haver antes estado aqui, saindo para trabalhar lá. A curiosidade em torno de mim: "Esta é Maura Lopes Cançado, a que escreveu 'No quadrado de Joana?' - O conto é realmente bom, mas pensar que a personagem dele é louca catatônica passou a aborrecer-me" (como as pessoas são estúpidas, ainda se pretendem ser gentis). Minha posição me marginalizava. As coisas simples não se ajustavam a nada em que eu pudesse tocar, sentir. Era a impressão (CANÇADO, 2016a, p. 27).

O relato acima foi escrito dias depois de sua internação no hospital do Engenho de Dentro, logo após uma das brigas na redação ${ }^{3}$ do Suplemento Dominical do Jornal do Brasil ${ }^{4}$, onde colaborava com poemas e contos publicados. De acordo com Maria Luisa Scaramella (2010, p. 79), não era a primeira vez que Maura buscava ajuda e refúgio no hospital

\footnotetext{
${ }^{2}$ A referida internação, de 1949, ocorreu entre abril e maio (SCARAMELLA, 2010).

${ }^{3}$ Das narrativas sobre Maura, Maria Luisa Scaramella (2010, p. 79) destaca algumas passagens das entrevistas com os jornalistas José Louzeiro, Carlos Heitor Cony e Assis Brasil, quando estes descrevem a colega de trabalho como sendo a protagonista de algumas brigas na redação do Jornal do Brasil. Um dos episódios que a pesquisadora descreve, relatado em entrevista por Assis Brasil, é quando Maura atirou uma máquina de escrever pela janela: "Causou tamanho tumulto que a polícia foi à redação e coube a Reynaldo Jardim, o diretor, resolver o problema" (SCARAMELLA, 2010, p. 79).

${ }^{4}$ O Suplemento Dominical do Jornal do Brasil (SDBJ) era um caderno cultural de literatura e artes que foi criado em 1956, por Reynaldo Jardim, e reunia jornalistas e críticos, tais como Ferreira Gullar, Assis Brasil, José Louzeiro, Mário Faustino, Carlos Heitor Cony, entre outros.
} 
psiquiátrico - era a terceira vez que se internara, por não conseguir adequar-se às pressões e sanções sociais de uma sociedade burguesa, moralista e religiosa, a qual estabelece um conjunto de regras que determinam, em seu sentido mais amplo, o modo de ser de cada indivíduo. A escritora assim descreve o seu lugar ocupado no mundo: "26-11-1959 [...] Um existir difícil, vagaroso [...] Sobretudo a certeza de que estou só. Sinto, e esta sensação não é nova, como se uma parede de vidro me separasse das pessoas, conservando-me à margem e exposta" (CANÇADO, 2016a, p. 77).

Nesse contexto, o papel da escrita tornou-se, como veremos, um mecanismo de sobrevivência para a escritora dentro do espaço do hospício. Celia Musilli (2014, p. 22) ressalta que, "escrever, para Maura, é a tentativa de vencer suas fragilidades, sua fragmentação interna, utilizando o plano simbólico da linguagem como quem remonta um quebra-cabeça". Assim, é possível afirmar que tal escrita, evocada pelas lembranças e recordações significativas sobre seu passado, bem como a narrativa do seu presente vinculada ao momento de sua internação, se constrói por meio de um corpo ${ }^{5}$ que não se comporta dentro de um padrão esperado, justamente por se constituir como um corpo não disciplinado, pelo qual ameaça ou transgride a ordem social (FOUCAULT, 1999 [1987]). Aqui, nos é oportuno destacar que no caso das mulheres, a razão de seus comportamentos considerados desviantes às morais vigentes estava majoritariamente relacionada à loucura feminina ${ }^{6}$. Nesse sentido, a escrita-testemunho de Maura Lopes Cançado consegue romper com as barreiras do silêncio ${ }^{7}$ nos posicionando nos caminhos do processo simbólico que ela atravessa, a partir de sua subjetividade manifesta na escrita literária. Nas palavras de Rosângela Lopes da Silva (2017, p. 15), "ao colocar a loucura no interior da linguagem, a literatura se afirma como possibilidade de ser palavra onde sempre houve silêncio".

Sua narrativa tem, portanto, como eixo principal o escrito sobre a loucura. Ao transpor as fronteiras da razão, segundo constata Gislene Silva (2008, p. 178), “o olhar da narradora pode transitar com liberdade pelos vários horizontes sociais e perceber as dinâmicas e os

\footnotetext{
${ }^{5}$ Segundo Michel Foucault (2010 [1979], p. 80), para além de uma categoria biológica, o corpo se constitui, em fins do século XVIII e início do século XIX, como objeto de produção e força de trabalho. Conforme o filósofo: "o controle da sociedade sobre os indivíduos não se opera simplesmente pela consciência ou pela ideologia, mas começa no corpo, com o corpo".

${ }^{6}$ Discutiremos melhor essa questão no capítulo 2 "Loucura e a escrita de si".

${ }^{7}$ Nos primórdios da constituição da Psiquiatria no Brasil, o discurso médico, motivado por razões políticas e sociais, concebeu a loucura como um estado de não razão, e isso justificou o internamento dos considerados loucos com o objetivo de silenciá-los, ou seja, afastá-los da sociedade através da coerção moral. O internamento assim se justificava no retorno da razão (MACHADO \& CALEIRO, 2008 , p. 4), o que muitas vezes resultou nas condições de tratamentos punitivos, tais como o eletrochoque, a lobotomia, entre outros.
} 
mecanismos de organização da sociedade". Eis porque a fala de um lugar onde a consciência do "eu" a princípio não parece existir ${ }^{8}$, desperta em nós, leitores, à primeira vista, não só curiosidade - a respeito de quem é esse "eu" que escreve -, como nos leva a refletir sobre a condição humana dentro de um espaço supostamente esquecido 9 .

Maura Lopes Cançado é um corpo simbólico e material que traz como marcas as inscrições culturais de seu tempo. Um corpo inscrito pelas contingências da experiência da solidão e que, num primeiro momento, escreve na condição de mulher louca ao trazer "a voz socialmente rejeitada e apartada da alteridade para o centro de reflexão" (SILVA, 2008, p. 169). Sua escrita constitui-se entre o final dos anos 1950 e início dos 1960 - décadas antecedentes à reforma psiquiátrica no Brasil $^{10}$, , "uma das primeiras denúncias na literatura das condições de tratamento desumano em que viviam as loucas no Rio de Janeiro nesse período" (CUSTÓDIO, 2017, p. 115). Ler, portanto, o seu relato implica compreender melhor os aspectos sociais e históricos que determinaram a sua condição de mulher louca.

Em função dessa literatura como instrumento de denúncia, a autobiografia intitulada Hospício é Deus, escrita em forma de diário, foi desenvolvida entre os anos de 1959 a 1960 e publicada pela primeira vez em 1965 -, durante a sua internação no hospital do Engenho de Dentro, no Rio de Janeiro. Entre uma internação e outra, no final dos anos de 1950, Maura escrevia contos e poemas para o Suplemento Dominical do Jornal do Brasil que aos poucos, publicava seus textos. Isso porque Maura era colaboradora desse jornal, e, em diversas passagens de seu diário, ela faz menção aos contos, que mais tarde reunidos, em 1968, constituíram a coletânea intitulada $O$ sofredor do ver. Nessas circunstâncias, acreditava-se a maior escritora da língua portuguesa (MEIRELES, 2016a, p. 204).

A literatura de Maura, justamente por retratar uma experiência limite, que é esboçada por meio de uma subjetividade extremamente sensível, oprimida e fragmentada, capaz de conferir à existência um sentido de morte em vida, reflete também os aspectos sombrios de uma realidade colocada à margem pelas normas da razão, sobretudo, pelo conhecimento

\footnotetext{
${ }^{8}$ É interessante frisar que durante muito tempo "a exclusão da loucura envolveu a exclusão da subjetividade" (ABOU-DY E LOBOSQUE, 1998 apud GOMES, 2014, p. 108).

${ }^{9}$ Um estudo acurado sobre a história das casas de internamento, concebidas no século XVII, nos mostra que inúmeros foram os motivos pelos quais se internavam as pessoas "tidas como alienadas", mas, certamente, a motivação maior que unia esse intento era a de eliminar aqueles considerados nocivos à sociedade (FOUCAULT, 2009, p. 114).

${ }^{10}$ Leísa Ferreira Amaral Gomes, em sua dissertação Loucura e gênero: uma análise da escrita autobiográfica, fala a respeito do contexto da reforma psiquiátrica brasileira, que ocorreu entre as décadas de 1970 e 1980, nos oferecendo um panorama das discussões que foram levantadas por estudiosos do assunto. Em resumo, a reforma psiquiátrica foi uma reação às condições de tratamento desumanas praticadas pelo antigo sistema psiquiátrico.
} 
psiquiátrico da época, o qual submetia aos pacientes tratamentos extremamente desumanos. Assim, Maura Lopes Cançado atraiu os olhares da crítica literária dos anos cinquenta aos setenta, por seu processo singular de escrita, em que texto, vida e literatura, compõem, essencialmente, a representação da loucura em seus diversos aspectos. A história de Maura é a história do seu corpo, das suas emoções, da violência que sofreu, da sua loucura, da literatura e da condição da mulher. De acordo com seus colegas de trabalho, Maura seria na literatura uma revelação, se não fosse pela sua condição psiquiátrica (MEIRELES, 2016a).

Essa afirmação, sobre o reconhecimento de Maura enquanto escritora de talento promissor se constrói, primeiramente, pela publicação de seu mais famoso conto "O quadrado de Joana" ${ }^{11}$, o qual foi publicado na primeira página do Jornal do Brasil e que lhe rendeu não só elogios dos leitores à época, como também lhe deu alguma notoriedade entre escritores e intelectuais, tais como Clarice Lispector, Assis Brasil, Otto Lara Resende e Ferreira Gullar. Em seguida, seu diário Hospício é Deus foi a obra que a lançou efetivamente no cenário literário nos anos 1960 na literatura brasileira, sendo que antes de sua primeira publicação, em 1965, já havia sido lançadas algumas pequenas notas sobre a escrita de um romance, conforme aponta os estudos de Anna Flávia Dias Salles (2017, p. 32), por conta dos textos publicados em suplementos literários. Dessa forma, o nome de Maura Lopes Cançado já era noticiado nos principais cadernos de arte do país, a exemplo de Letras e Artes do Diário Carioca, em 26 de abril de 1959 (SALLES, 2017, p. 32). Salles ressalta que: "Em 16 de fevereiro de 1960, as primeiras referências à obra como um diário, ainda sem título, ocorrem no $1^{\circ}$ Caderno do $J B$ " (2017, p. 33). O nome de Maura estava, então, entre as personalidades em destaque nesse período, que a fazia despontar na literatura brasileira contemporânea. Segue a passagem do Jornal do Brasil sobre o diário em produção:

\section{DIÁRIO SOBRE UM HOSPITAL PSIQUIÁTRICO}

Um documento da mais alta importância humana e social será publicado em breve pelo Jornal do Brasil. Trata-se de um diário escrito por Maura Lopes Cançado que se acha internada num hospital psiquiátrico. Tanto o lado alegre e pitoresco quanto o lado patético e trágico são observados pela escritora com um notável senso crítico. Esse trabalho mostrará as reações mais íntimas de uma criatura que se submeteu à vida de um hospital desse gênero (JB, 16/02/1960, p. 35).

\footnotetext{
${ }^{11}$ Na primeira página do SDBJ, em 16 de novembro de 1958, foi publicado "No quadrado de Joana", conto sobre uma paciente catatônica (SCARAMELLA, 2010, p. 46).
} 
Contudo, ainda que os contos e o diário lhe dessem visibilidade, Maura sentia certo desconforto, como lhe era habitual, por perceber que tal prestígio não advinha somente de uma apreciação de sua escrita literária, mas, sobretudo, do estigma e rótulo que lhe era colocado, a da escritora louca. Tal irritação é expressa no seguinte fragmento: "A curiosidade em torno de mim: Esta é Maura Lopes Cançado, a que escreveu 'No quadrado de Joana?' [...] (como as pessoas são estúpidas, ainda se pretendem ser gentis)" (CANÇADO, 2016a, p. 27). A escritora assim manifesta a decepção que tal visão causa nela, já que considera sua escrita importante e reconhece que é necessário e indispensável falar de um lugar no qual pouco se sabe.

8-2-1960 [...] Não me comove ouvir falar do meu talento. O que me separa dos outros, não importa o nome que lhe deem, é demais evidente, principalmente para mim. Desde pequena percebi que um destino diferente me estava reservado. Jamais sou como as pessoas que me cercam (CANÇADO, 2016a, p. 168).

Ainda hoje é possível notar, de acordo com o professor de Literatura Brasileira Gilberto Araújo (2018, p. 118), quando ele diz em seu ensaio "O romance em Maura Lopes Cançado", que a biografia da autora é a "chave de leitura unívoca de sua obra". Segundo ele, o espaço da narrativa em Hospício é Deus, por encerrar a escrita de primeira pessoa e vincular a experiência das internações, reforça a leitura em chave biográfica - além de duas referências predominantes nos estudos dedicados à autora, quais sejam: A história da loucura, de Michel Foucault (2009) e O pacto autobiográfico, de Philippe Lejeune (2008). Felizmente, segundo o professor, a literatura contemporânea brasileira tem dado vislumbre aos escritores que vivenciaram o "isolamento manicomial” (ARAÚJO, 2018, p. 118), tais como Renato Pompeu, Rodrigo de Souza Leão e Stela do Patrocínio, e, com isso, a crítica tem realçado "a potência criativa" (ARAÚJO, 2018, p. 118) das escritas de si, cujas narrativas são também capazes de sobrelevar a linguagem em composição literária.

O que é preciso retirar dessa discussão, a fim de manter a coerência com nossa proposta de análise, é que nos estudos que versam sobre a autora, é consenso entre os estudiosos que é impossível separar vida e obra, já que a vida de Maura Lopes Cançado constitui elemento principal para a sua matéria literária. Importa ressaltar aqui, que consideramos problemática a leitura que leva em conta, exclusivamente, a vida pessoal do escritor, visto que todo o trabalho com a escrita impõe um distanciamento da experiência empírica, mesmo que o autor imprima em seu texto as experiências que viveu. 
Sendo assim, o objetivo deste capítulo é agrupar a pequena fortuna crítica de Maura Lopes Cançado, embasando-nos em uma possível trajetória biográfica, com o intuito de compreender seu processo de escrita, precisamente, Hospício é Deus - Diário $I^{12}$, objeto desta dissertação. Seguimos, antes, com o seu retrato biográfico.

\subsection{A VIDA QUE SE ESCREVE}

Acredito ter sido uma criança excepcional, monstruosamente inteligente e sensível, perplexa e sozinha (CANÇADO, 2016a, p. 19).

Vinda de família rica tradicional mineira, Maura Lopes Cançado nasceu no interior de uma fazenda em Minas Gerais, no dia 27 de janeiro de 1929, na pequena cidade de São Gonçalo do Abaeté. Era a nona de onze filhos (SCARAMELLA, 2010). Seus pais José Lopes Cançado e Affonsina Álvares da Silva tiveram grande influência na sua formação, sobretudo, seu pai, para quem a admiração se faz presente em várias passagens de suas memórias, como descreve a seguir:

Aquele homem, vivendo à margem da civilização, aquele homem temido e forte, possuía uma dimensão desconhecida a si mesmo. Podia ter sido um Wagner, um Nietzsche ou um Napoleão. Não fora a limitação do seu meio, seria o maior personagem que conheci (CANÇADO, 2016a, p. 10).

José Lopes Cançado foi um rico e respeitado fazendeiro da região de seu entorno, cultivando não só o destaque na política e economia mineira, como também tinha certo alcance social e político em âmbito nacional (SCARAMELLA, 2010). Após ter gastado toda sua herança na juventude, casou-se com Affonsina, mais conhecida como dona Santa. Era, aos olhos de Maura, "modesta, generosa e quieta" (CANÇADO, 2016a, p. 11).

Dona Santa era também proveniente de família importante em Minas Gerais, os Álvares da Silva. Dessa linhagem aristocrática, conforme registra Maria Luisa Scaramella

12 O Diário I nos remete à um segundo volume que, por razões que desconhecemos, mas não ignoramos, não foi publicado - porque certamente incomodava (MEIRELES, 2016a, p. 227). Segundo os estudos de Cinara de Araujo (2002), alguns depoimentos sinalizam que o Diário II seria muito mais além do que o primeiro, na medida em que Maura, repetidas vezes, comentava que estava escrevendo o segundo diário e que este, sem dúvida, seria mais embaraçoso. "Mas o livro não é editado. No ano de sua morte, 1994, os originais estavam com o editor José Álvaro que faleceu sem publicá-lo" (ARAUJO, 2002, p. 27). 
(2010, p. 2) em seu estudo etnográfico ${ }^{13}$, Maura é descendente de Dona Joaquina do Pompéu, matriarca que viveu entre o fim do século XVIII e começo do XIX. Este fato é também verificado no relato de Maura quando descreve sobre essa mulher, que segundo os registros históricos, era influente à época: "Sei que sou descendente de Joaquina de Pompéu, mulher extraordinária - que durante o Império manteve o poder político em Minas, entretendo com Dom Pedro II relações políticas e amistosas” (CANÇADO, 2016a, p. 11).

Criada no interior de uma fazenda, Maura Lopes Cançado foi uma criança que desde o início recebeu atenção e cuidados excessivos por parte da família e dos empregados. Um dos exemplos significativos que marcaram sua infância é que até os setes anos de idade Maura era vestida com roupas na cor azul e branca por conta de uma promessa que sua mãe fizera à Virgem Maria, para que a menina se recuperasse das muitas doenças que tivera desde cedo.

Outro episódio descrito em seu relato é quando Maura comenta sobre a morte do seu padrinho Antônio, conhecido por Pabí. Segundo a autora, Pabí cresceu junto à família de Maura e era considerado como um filho para os pais da menina. Contudo, após a morte do padrinho, Maura relata que dona Santa havia ficado apreensiva, "temendo que o houvesse enterrado vivo por não estar de todo rígido, nem totalmente frio" (CANÇADO, 2016a, p. 12). Dentro de alguns dias, José, o irmão de Maura, havia dito que vira Pabí numa aparição e este lhe dizia que voltaria para buscar a menina. Tão logo ouviu essa declaração, Maura, ainda com seus quatro anos de idade, acreditava que também morreria em breve. Essa inquietação, segundo a autora, seria, possivelmente, o gatilho para o começo de sua "neurose de morte" (CANÇADO, 2016a, p. 12). Ela diz: "Prestaram atenção em mim exageradamente. De certa forma isso me trouxe grande solidão - por não me sentir bem uma menina" (CANÇADO, 2016a, p. 12). Isso porque, além desses fatos, a autora acredita que seu destino de louca já estaria traçado na gênese de sua família, por conta de seu irmão, João, considerado louco:

Ficou doente aos quatro anos, em consequência de uma meningite, morreu aos quatorze e quase não me lembro dele. Sim, andando pelos currais da fazenda, rasgando os macacões que lhe vestiam, sua morte, antecedida de vários ataques, o caixão, as flores, mamãe chorando e eu não entendendo bem (CANÇADO, 2016a, p. 9).

\footnotetext{
${ }^{13}$ Como veremos no terceiro capítulo desta dissertação, estudo etnográfico compreende um trabalho de pesquisa no local do objeto de estudo do pesquisador e, geralmente, esse trabalho é feito por um antropólogo, mais precisamente, um etnógrafo. Maria Luisa Scaramella empreendeu essa pesquisa etnográfica visitando alguns locais em que Maura viveu, tais como Patos de Minas e Rio de Janeiro, encontrando-se com familiares, amigos e colegas de trabalho da escritora.
} 
Dessa maneira, a autora constrói uma relação com o medo e a angústia a partir das experiências da infância, emoções essas que marcariam sensivelmente a sua vida adulta. Além do medo de ser enterrada viva, por consequência das palavras proferidas de sua mãe - quando essa disse que temia que seu padrinho fosse enterrado vivo -, Maura, aos cinco anos de idade, sofreu o drama do estupro, fato este ocorrido com um rapaz, um dos empregados, que tomava conta da fazenda. Essa mesma situação se repetiria mais duas vezes com dois outros empregados. Nas palavras da autora: "O sexo foi despertado em mim com brutalidade" (CANÇADO, 2016a, p. 18).

Assim, instaura-se o sentimento de culpa que teria sido, inclusive, o motivo pelo qual Maura temia a figura de Deus, cuja entidade soberana lhe mostrava ser inquisidora e cruel, à medida que esse Deus se fazia constantemente presente em todos os momentos de sua vida. Ela confessa:

Diziam-me que os maus iam para o inferno e o sexo era uma vergonha, um ato criminoso. Era sensual, e má, portanto. Então Deus se me afirmou em razão da maldade. [...] Costumava pensar: "Cristo veio à Terra em forma de homem; Cristo teria sexo? Mas sexo? Pensar isto de Jesus? - Já pensei e Deus sabe. Ele sabia, mesmo antes de eu pensar". Meu complexo de culpa tornou-se tanto, que ficava chorando pelos cantos da casa, todos indagando intrigados: "Que tem esta menina, está doente?". E foi esta Divindade que me ensinou a mentir: diziam: "Devemos amar a Deus sobre todas as coisas". Sim, concordava com veemência e mentira. [...] Minhas relações com Deus foram as piores possíveis - eu não me confessava odiá-lo por medo da sua cólera. Mas a verdade é que fugia-lhe como julgava possível - e jamais o amei. Deus foi o demônio da minha infância (CANÇADO, 2016a, p. 17).

Esses sentimentos de repulsa e de ódio têm a ver com o importante papel de dominação que a Igreja desempenhou, durante séculos, na sociedade Ocidental e, no caso do Brasil, desde o Período Colonial. Compreender o poder de influência que essa instituição religiosa cristã exerceu, e ainda exerce, no comportamento e na mente das pessoas, nos ajuda a entender parte da situação dramática da autora. Em relação à influência da Igreja no Brasil Colonial $^{14}$, a historiadora Mary Del Priore discorre a respeito:

Ela regulamentava o cotidiano das pessoas pela orientação ética, pela catequese, pela educação, pelo ritmo semanal recortado pelo domingo e pelo calendário anual marcado pelo Advento; o Natal, a Quaresma, a Páscoa e pelo ciclo santoral dos diferentes apóstolos, confessores e sobretudo pelas festas de Nossa Senhora. A Igreja fazia-se presente ainda nos momentos

\footnotetext{
${ }^{14}$ É significativo o fato de que a influência da Igreja Católica e as demais instituições religiosas cristãs ainda assumem força na consciência coletiva da sociedade contemporânea.
} 
chaves da vida como o batismo, a eucaristia, o casamento, a extrema unção, os funerais, a penitência e os demais gestos que acompanhavam o dia-a-dia das pessoas, do nascimento à constituição da família, da reconciliação à morte, da reza doméstica às celebrações coletivas (1990, p. 24-25).

Em razão disso, observemos o seguinte excerto no qual Maura demonstra a sua inquietação diante da figura de um Deus, concebida, aos seus olhos, como um ser que tudo controla e que lhe impôs, desde cedo, empecilhos e julgamentos. Como resultado dessas expressões do medo e da angústia no período da infância, as quais permaneceram conservadas em seu íntimo na vida adulta, esse mesmo Deus a conduziria, mais tarde, ao triste caminho do hospício:

Aos 5 anos, talvez antes, travei conhecimento com o sexo, vendo os animais na fazenda e ouvindo meninas, filhas de empregados. Ensinaram-me a encará-lo como coisa feia e proibida. Passei a sentir-me constantemente em falta, por ser grande minha curiosidade sexual. "É pecado fazer coisas feias", diziam-me. E eu sentia grande prazer nas coisas feias. Mais ou menos nesta época me impuseram deus, um ser poderoso, vingativo, de quem nada se podia ocultar. A resistência em me preocupar com a imortalidade da alma. Por que temia ser enterrada viva, ao invés de temer algo mais sério, o Julgamento Divino? O inferno me estava reservado, tinha quase certeza, entanto meu verdadeiro medo era imaginar-me sob os sete palmos de terra, sem me mover ou respirar (CANÇADO, 2016a, p. 16).

Aos sete anos de idade Maura sofreu a primeira crise convulsiva, repetindo-se aos doze, aos quatorze e duas vezes aos quinze anos - durante a gravidez e depois da morte do pai. Mais a frente, com a idade de dezessete anos, quando retornaria às aulas de aviação, a autora seria, frequentemente, acometida de pânico ao imaginar que essas crises pudessem ocorrer novamente, especialmente quando estivesse voando sozinha. Ela escreve no relato: "Não excluía mesmo a hipótese de ser epilética, isto me parecia horroroso, costumava afirmar à mamãe preferir a morte à repetição de uma crise" (CANÇADO, 2016a, p. 24).

Os primeiros anos de sua educação formal ocorreram em Patos de Minas, quando Maura foi morar nessa cidade para estudar o primário, que à época era em regime de internato. Aos quatorze anos entrou para um aeroclube, com o objetivo de obter brevet de piloto. Desse contexto, conhece um jovem aviador, Jair Praxedes, um rapaz de dezoito anos com quem decide se casar. Seu pai, tão logo soube do desejo de sua filha, rejeitou veementemente tal intenção. Ela declara: "Papai sofreu acima de suas forças, ele que fazia em relação a mim os mais bonitos projetos. Pediu-me, prometeu ceder a todas as minhas vontades. Não escutei” (CANÇADO, 2016a, p. 20). Assim sendo, Maura se casa, 
permanecendo nesse casamento por um período de um ano e dessa união deu a luz à Cesarion, seu único filho:

\begin{abstract}
Aos quinze anos vi-me com o casamento desfeito, um filho e sem papai, sustentáculo de todos os meus erros - meu grande e único amor. Restava-me mamãe: para sofrer com minha insatisfação, meus ideais irrealizáveis, minha busca do "não sei o que é, mas é maravilhoso", minha vaidade e meu tédio pelo que me estava às mãos (CANÇADO, 2016a, p. 22).
\end{abstract}

A partir de então, com o casamento desfeito e com a morte do pai, Maura tenta recomeçar a sua vida, porém encontra obstáculos em uma sociedade mineira conservadora, que a impedem de seguir seus caminhos como mulher divorciada ${ }^{15}$ e com um filho. A vida doméstica e de mulher casada ${ }^{16}$ dos anos quarenta não cabia para Maura Lopes Cançado, e, por isso, ela não encara seu papel feminino, de cuidar do lar e submeter-se ao homem como algo natural. Por conta disso, sua vida é marcada, desde cedo, pelo estigma da mulher que subverte a moral religiosa e os costumes da época. Ao querer colocar a vida em ordem, ela afirma:

\begin{abstract}
Desfeito o casamento, que só se realizou na Igreja, por minha pouca idade, julguei possível recomeçar minha vida como se nada houvesse acontecido. Morávamos numa cidade próxima à fazenda, São Gonçalo do Abaeté. Diziam-me a moça mais bonita e prendada da cidade. Lamentavam que me tivesse já casado. Aquilo me irritava deveras. Lera muito sobre os costumes de outras terras, julgava-me na situação de uma divorciada (ou menos comprometida). Por que privar-me das diversões comuns às moças da minha idade? Mas as pessoas pensavam diferente. Atravessei nesta época uma fase completamente niilista. Li todos os filósofos que me caíram às mãos. Não possuindo ainda grande defesa, deixei-me impregnar de negativismo apenas. Pensei pela primeira vez em me matar (CANÇADO, 2016a, p. 22-23).
\end{abstract}

Ao questionar a composição social de seu tempo, Maura está indo ao desencontro de uma ideia de gênero que é historicamente construída (BUTLER, 2012), mas, em sua visão,

15 Segundo a historiadora Carla Bassanezi Pinsky, em seu artigo intitulado "Mulheres dos anos dourados": "O divórcio, considerado por muitos um veneno para a estabilidade social por enfraquecer a instituição familiar ou servir como porta de entrada para o amor livre, só passou a fazer parte das leis brasileiras na década de setenta" (2017, p. 636-637, destaque da autora).

${ }^{16}$ Ainda sob a influência da Igreja no Período Colonial, cumpre observar que não era incomum o fato de as meninas e os rapazes se casarem muito jovens, pois existiam leis da Igreja que permitiam tal emancipação por meio do casamento. Assim, por exemplo, as meninas podiam casar-se aos doze anos, enquanto que os meninos aos quatorze. Entretanto, essa realidade não era a regra e muitos se casavam entre os dezoito e vinte um anos (DEL PRIORE, 1990). Importante esse entendimento pelo fato de que a herança de muitas tradições do Brasil Colônia se fez presente também em meados do século XX. E por esse motivo, não era estranho que, na década de 1940, Maura, mesmo sendo uma menina, se casasse com os seus quatorze anos. 
procura romper com os padrões sociais que lhe foram impostos desde o seu nascimento. A jovem Maura já demonstrava ter uma percepção diferente acerca da realidade mineira dos anos de 1940 e 1950, pela qual a imagem feminina estava relacionada à maternidade e ao lar, e cujo universo desenhava para a mulher o papel de esposa, mãe, educadora e dona de casa, ou seja, sem espaço em outros contextos de expressão social. E ao encarar o futuro como sendo idealizadora de seu destino, Maura tentou buscar autonomia para definir como seria dada essa realização. Entretanto, por mais que questione os comportamentos esperados dela, Maura não consegue reunir forças para transcender a condição de mulher subalterna, cujo papel social feminino é fortemente marcado no seu tempo, dado às imposições dos códigos religiosos e morais da época. Com isso, há uma tensão que soma às outras.

Não obstante a sociedade lhe censurar por viver da forma como desejava, superado os conflitos que passara logo após ter desfeito o casamento, Maura, aos dezesseis anos, entra outra vez para o aeroclube. Nesse momento, é necessário reconstruir e recuperar os anseios de menina antes do casamento. Nas aulas de aviação, Maura é a única moça da turma e a única a possuir um avião entre os colegas do aeroclube. Sua mãe lhe presenteara com um avião "Paulistinha, Cap 4 - Prefixo PP-RXK"17, o qual foi batizado por ela de Cesarion. Ela lembra: "Sabia que minhas atitudes de aviadora, consideradas 'livres', agrediam a falsa moral (que naquele tempo eu não ousava chamar de falsa)" (CANÇADO, 2016a, p. 23). Desta feita, seu avião foi quebrado por um amigo seu, também aviador, ao tentar uma aterragem de emergência na rua de uma cidadezinha. Maura diz que o avião caiu sobre uma casa quase matando os habitantes.

Essas descrições são apenas um exemplo de como, naquele período, o comportamento, as atitudes e as expressões de Maura fugiam as concepções tradicionais da mulher de seu tempo. Segundo o relato do jornalista Pedro Rogério Moreira ${ }^{18}$, apresentado no estudo de Maurício Meireles (2016a, p. 210): "todo mundo na cidade falava daquela menina que pilotava um avião. Ela era muito audaciosa, por isso as mulheres tinham inveja dela. Era vista como bonita, mas também como libertina".

17 "Maura, na adolescência, sentia um medo danado de despencar dos ares. Mas desafiava o temor. A bordo de um avião Paulistinha, máquina de dois lugares e motor de 65 cavalos, ela sobrevoava as fazendas de Minas Gerais" (MEIRELES, 2016a, p. 206).

${ }^{18}$ Pedro Rogério Moreira, neto do presidente do aeroclube, é um jornalista que escreveu um romance intitulado Bela noite para voar, no qual a personagem principal, Princesa, foi inspirada em Maura. O autor, quando criança, sabia da existência de uma jovem que pilotava aviões, posto que morava em Bom Despacho, cidade mineira onde Maura frequentava o aeroclube. E quando escreveu o romance, não sabia que se tratava de Maura. Foi por meio do seu colega de trabalho, Cesarion, filho da escritora, que descobriu, anos depois, a coincidência (SCARAMELLA, 2010, p. 98). 
Sua conduta era, portanto, submetida aos olhos atentos da sociedade. À vista disso, a autora desabafa:

\begin{abstract}
Mas casamento? - Até me descasara. O casamento, porém, nunca fora real. Mulheres me olhavam pensativas: "Tão nova já com este drama". Que drama? Me perguntava irritada. Os homens se aproximavam violentos, certos de que eu devia ceder: "Por que não, se já foi casada?". Moças de "boas" famílias me evitavam. Mulheres casadas me acusavam de lhes estar tentando roubar os maridos. Os tais maridos tentavam roubar-me de mim mesma: avançavam. Eu tinha medo (CANÇADO, 2016a, p. 23).
\end{abstract}

Nesse sentido, à medida que a autora vai tomando consciência de seu passado, ela desponta a certeza de que não estava seguindo os caminhos que foram traçados para ela cumprir com os princípios de uma sociedade burguesa mineira -, mas, ainda assim procurava os meios de fazer com que sua verdade pudesse, de alguma forma, ser vivida. Ela diz: "Eu crescia e cresciam meus temores: o escuro, a noite, a morte, o sexo, a vida - e principalmente Deus: de quem nada se podia ocultar" (CANÇADO, 2016a, p. 17).

Vimos, até então, a primeira parte de seu livro Hospício é Deus. Nas primeiras páginas, Maura procura descrever aspectos e memórias de sua infância, se retratando até os dezessete anos. Com isso, busca revisitar o passado com o intuito de compreender a sua condição de mulher louca, que não consegue uma posição em uma sociedade marcadamente engessada pela consciência patriarcal. Após o retorno de seu passado, temos, em seguida, o diário propriamente dito, em que encontramos também fatos ocorridos até a chegada no hospital.

\title{
2.2 FORTUNA CRÍTICA
}

Só sou autêntica quando escrevo. O resto do tempo passo mentindo (CANÇADO, 2016a, p. 169-170).

Esta seção tenciona reunir parte da fortuna crítica da escritora Maura Lopes Cançado, a fim de demonstrar como a experiência de sua escrita em Hospício é Deus - Diário 1, é discutida do ponto de vista de pesquisadoras dos campos da Teoria Literária, da Psicologia e das Ciências Sociais, que se propuseram analisar essa obra, em especial no que toca à produção do diário, conforme é apresentado no subtítulo do livro. Assim, analisamos os trabalhos acadêmicos - teses e dissertações -, até então produzidos, compreendidos entre os 
anos de 2002 a 2017. Nosso objetivo caminha no sentido de compreender de que maneira a obra da escritora se estrutura no espaço poroso da fronteira da escrita do eu, em uma situação em que o confinamento no hospício constitui como experiência que advém de uma realidade de profundo sofrimento. Nesse ponto, indagamos: como é feita a produção dessa escrita?

A princípio, o livro de Maura Lopes Cançado é tratado como um diário íntimo em que a autora escreve sobre as suas experiências no hospício. Partindo dessa análise, tomamos como referência os estudos do teórico francês Philippe Lejeune (2008, p. 261), para quem define o diário íntimo como um processo de escrita que se faz no dia-a-dia no qual encontramos uma série de fragmentos e repetições dos registros dos acontecimentos, não havendo o compromisso com a ordenação dos fatos. Assim, tanto a forma como o conteúdo serão livres, e tal escrita pode ajustar-se como exercício da memória do diarista, ou, como uma atividade artística para o escritor. Entretanto, a escrita do diário, segundo Lejeune, não é, a rigor, pensada para o formato de livro. Uma vez que isto acontece, o diário perde seu caráter de confidência, revelando, assim, a intenção de publicação.

Apontando para essas questões, o livro da autora não se encaixa na definição de diário íntimo na acepção do crítico francês. Objetivamente, nosso estudo se fundamenta na constatação de que Hospício é Deus abarca três gêneros, a saber: memórias, relato autobiográfico e o diário não íntimo. É, portanto, seguro afirmar que, Maura sabia que seu diário seria publicado, já que desde o início de sua entrada na redação do jornal a escritora tinha pretensões literárias. Além disso, o incentivo para tal escrita foi feito pelo editor do SDBJ, Reynaldo Jardim, como ela sinaliza em seu diário: “19-11-1959 Reynaldo sugeriu-me escrever um diário. Respondi que já registro todas as minhas impressões. Ele gostaria de publicar o diário no jornal” (CANÇADO, 2016a, p. 61). Desse modo, compreendemos que, em Maura, há uma ruptura com a tradição clássica da escrita do diário como sendo um espaço íntimo e acolhedor, onde o "eu” confessa para si o inconfessável (FAEDRICH, 2013, p. 128).

Nesse contexto, com o propósito de ampliar nossa visão sobre a narrativa de Hospício é Deus, reunimos, a seguir, algumas análises que consideramos importantes nesta pesquisa.

Tinha medo de ver, num mesmo olhar, um trem e um passarinho: a escrita íntima em Maura Lopes Cançado, dissertação de mestrado desenvolvida por Cinara de Araujo (2002), mune-se de conceitos importantes e complexos que incursionam por uma visão simbólica muito instigante, sobre a relação entre o que é e o que parece ser. Ao investigar a escrita de si na modernidade, ela busca refletir sobre os traços de escrita nas obras da autora, atentando-se para o lugar desconfortável que os discursos autobiográficos ocupam em termos de gênero 
(2002, p. 18). Ela então assinala que "já não é profícuo costurar a pessoa do autor à sua obra”, e prossegue sua análise afirmando que, nos escritos de Maura, "a 'verdade' dos fatos vividos, não é a mesma 'verdade' da história que se conta” (2002, p. 53).

Assim é que,

Ao tomarmos novamente tais colocações sobre esta vida que se movimenta na literatura, temos a narrativa em excesso, o relato desmedido que povoa a escrita de Maura em seu diário. Também aí encontramos a história de Maura Lopes Cançado, ponto cheio demais, impossível de não ver. [...] persigamos a tensão que se enovela em seu projeto de escrita, que ora perfura um buraco ausente de fatos, ora parece querer nos convencer de que os acontecimentos, as datas, os nomes fazem parte daquilo que chamaríamos realidade (ARAUJO, 2002, p. 9).

Em sua dissertação de mestrado intitulada Vida surgida rápida, logo apagada extinta: a criação de estratégias de fuga do hospício na escrita de Maura Lopes Cançado, Mariana Patrício Fernandes (2008) medita, entre outras coisas, sobre a presença do leitor quando este está diante de um relato marcado pela "experiência do cárcere e da claustrofobia". Seu interesse de pesquisa tem como objetivo demonstrar, em certa medida, que existe não uma única chave de leitura para o diário da autora, mas, diversas possibilidades de leituras, evidenciando, dessa maneira, o papel do leitor no processo de construção de sentido diante de uma escrita que, segundo ela, tem como objetivo premente encontrar leitores que possam escutá-la a fim de que suas palavras não se percam no espaço vazio.

Embora a escrita de cunho autobiográfica em Hospício é Deus, faz, à primeira vista, crer que texto e assinatura sejam uma coisa só, já que a vida de Maura Lopes Cançado coincide com a figura da narradora em primeira pessoa, concordamos com Fernandes (2008) quando diz que é importante dissociarmos a leitura da identidade do "eu" da autora da personagem-narradora do livro. Ter isso em mente significa, segundo ela, questionar o lugar do leitor diante dessa escrita, pois tanto a história da vida de Maura, quanto a sua narrativa, converge para um mesmo ponto, sendo difícil delimitar precisamente as fronteiras entre experiência vivida e narrativa (FERNANDES, 2008, p. 30).

Certamente, reconhecemos que, tanto no diário como no livro de contos, a experiência de confinamento é o que define os escritos de Maura, haja vista que a escritora passou grande parte da sua vida internada em hospitais psiquiátricos ${ }^{19}$. E a despeito do leitor, a pesquisadora afirma ser impossível ficar imune à escrita da autora e, desse ponto, ela nos focaliza algumas

${ }_{19}$ De acordo com os estudos de Maria Luisa Scaramella (2010, p. 181), "Maura foi paciente das instituições manicomiais brasileiras ao longo das décadas de 50,60, 70, até sua morte, em 1993". 
chaves de leitura, quais sejam: a primeira delas consiste no relato de testemunho, no qual a escritora nos mostra a difícil realidade de quem vive no hospício nos conduzindo à experiência da loucura, ao mesmo tempo em que nos convida a pensar na condição da mulher fora e dentro desse lugar; a segunda é a que trata sobre a marginalidade da vida de Maura dos momentos de sua infância, passando pelas pensões e hotéis em que ficava hospedada; da convivência no jornal, até a entrada no hospício, somos também testemunhas de suas experiências, sobretudo, da condição de excluída de todos os processos da dinâmica social ${ }^{20}$.

Outra leitura expressiva é a literatura de denúncia, sendo inegável reconhecermos Hospício é Deus como documento histórico. Contudo, a pesquisadora declara que esse tipo de leitura é problemático, chamando a atenção para o fato de que ao estabelecer uma submissão da escrita de Maura às circunstâncias em que foi produzida, cria-se, consequentemente, "uma barreira entre o leitor e aquelas palavras que pretendiam desestabilizá-lo, como uma realidade inteiramente alheia da vivida por quem lê" (FERNANDES, 2008, p. 30). Para tanto, ela continua dizendo que, se considerássemos Hospício é Deus apenas como testemunho ou documento histórico, correríamos o risco de ignorar os diversos questionamentos que a autora coloca, tais como a experiência da loucura e sobre sua identidade dilacerada representada pela escrita. Em síntese, seguindo os passos de Fernandes, é importante pensarmos em outras relações entre literatura e vida que não àquela que associa a escrita tão somente com o sujeito que escreve. Para ela, o diário caracteriza-se como espaço de sobrevivência no qual Maura Lopes Cançado cria modos de fuga para viver no hospício. E é por meio desse relato que a autora busca organizar as experiências com o intuito de fazer com que suas palavras ultrapassem os muros que a cercam.

A tese intitulada Olhando sobre o muro: representações de loucos na literatura brasileira contemporânea, de Gislene Maria Barral Lima Felipe da Silva (2008), tem por finalidade analisar a representação de personagens loucos e suas caracterizações no plano literário. Segundo a pesquisadora, a depender da forma como a personagem louca é retratada no texto, sua representação pode muitas vezes reforçar estereótipos negativos já existentes ou contribuir para uma visão emancipatória em torno de sua imagem - além de nos permitir conhecer o pensamento da sociedade representada sobre a figura do louco ${ }^{21}$.

\footnotetext{
${ }^{20}$ Esse tipo de leitura é que atrairia o público, ao considerar que, "diante de um contexto histórico em que a classe média está repensando o tradicionalismo dos seus valores, em um cenário de ditadura militar, esse tipo de comportamento desviante se apresentaria como objeto de consumo" (MEYHI, 2004 apud FERNANDES, 2008, p. 27).

${ }^{21}$ As obras analisadas nessa tese são: "A doida" (1951), de Carlos Drummond de Andrade; "Sorôco, sua mãe sua filha" (1962), de Guimarães Rosa; "As voltas do filho pródigo" (1970), de Autran
} 
Como comenta Gislene Silva (2008), a representação literária da loucura é, muitas vezes, construída a partir do ponto de vista de uma retórica da negatividade, em que a voz do sujeito louco é excluída do espaço social e, por esse motivo, compreendemos esse percurso frequentemente traçado por muitos escritores acerca da loucura ou do personagem louco, o qual é ancorado sob a égide de "representações do sujeito de um sistema filosófico cartesiano, dono de uma razão que não comporta nem considera a existência do outro" (SILVA, 2008, p. 151). Assim, não possuindo voz no contexto social e não propondo a sua própria versão sobre a realidade, o louco é julgado sob o olhar redutor de uma suposta razão, a qual insiste afirmar que o diferente é resultado de uma ausência de razão. Por outro lado, não podemos esquecer que a visão romantizada do sujeito louco também faz parte de um longo processo histórico, sendo, pois, responsável por construir uma imagem idealizada e romântica em torno de sua figura, de maneira que: o louco, ou é visto como aquele que vive conforme seus anseios - sem prender-se às imposições sociais; ou sua imagem está, por vezes, identificada na relação entre a criação e a imaginação.

Desse modo, a fim de considerar a loucura como processo criativo, diferentemente dos escritos que falam sobre o louco, na análise que trata sobre Maura Lopes Cançado, Gislene Silva (2008) busca investigar a autorrepresentação ${ }^{22}$ em Hospício é Deus, com o intuito de compreender como é construída essa autoimagem da autora que assume a identidade da mulher louca na escrita literária. Ela considera a obra de Maura como uma construção literária transgressiva, escrita na forma de diário, na qual a autora busca, por meio da palavra, representar uma minoria excluída dos processos de produção cultural. Conforme registra Gislene Silva:

Tão importante e necessária quanto a representação literária das minorias é a abertura de espaço no sistema literário, incorporando a própria voz desses grupos e acolhendo a fala da alteridade como espaço de uma nova identidade. Isso porque essa fala traz elementos de identificação, de questionamento e de ruptura com a visão da margem como espaço destinado a tais grupos (2008, p. 156).

Disso decorre que, ao inscrever as experiências no diário, Maura converte tais páginas em um lugar que fomenta discussões "sobre o fenômeno da loucura, problematizando os vários sentidos do conceito, seus aspectos filosóficos e culturais e a hierarquização dos loucos

Dourado; Armadilha para Lamartine (1976), de Carlos Sussekind; O exército de um homem só (1973), de Moacyr Scliar; O grande mentecapto (1979), de Fernando Sabino.

${ }^{22}$ Sobre autorrepresentação, Gislene Silva (2008) também analisa a obra Reino dos bichos e dos animais é o meu nome (2001), da escritora Stela do Patrocínio. 
em diferentes graus" (SILVA, 2008, p. 176). Assim ela frisa que o espaço do hospício é um local em que a falta de humanidade nas relações médico-paciente e funcionário-paciente assume papel preponderante no tratamento dispensado aos doentes mentais e, com isso, ela manifesta sua indignação e repúdio frente ao sistema psiquiátrico.

Junto a essas reflexões, Gislene Silva (2008, p. 158) assinala que, ao traçar a trajetória de sua loucura, assumindo a identidade de louca, Maura Lopes Cançado cria uma personagem a partir da construção de si mesma e, dessa experiência, ela "exercita a liberdade da palavra literária, e então linguagem artística e linguagem da loucura se infiltram uma na outra”. Compreender isso significa resguardar-nos do preconceito comum de que o sujeito louco, herdeiro de uma identidade historicamente fragmentada, não possui consciência de sua condição e criação artística, bem como de sua percepção sobre o mundo. Para a pesquisadora a escrita de Maura é uma escrita que não se desvia da razão, considerando-a, pois, lúcida e transparente, não traindo a lógica do pensamento e discurso. Ela acrescenta ainda, que a escrita da autora é traduzida como uma experiência bem-sucedida no campo literário, argumentando que as faltas e os descontroles que Maura cometem estão mais próximas do desejo de romper com um consenso de uma moral social, "do que propriamente de uma doença mental ou de uma linguagem desviante" (SILVA, 2008, p. 163). Decerto, a literatura de Maura é um meio pela qual é possível discutir e problematizar esse espaço de reclusão, tal qual nos permite discorrer acerca das identidades marginalizadas, especialmente àquelas que são excluídas dos processos de produção cultural.

O objetivo da dissertação Loucura: a temática que constrói o discurso da obra "Hospício é Deus", de Maura Lopes Cançado, é analisar como é construída a linguagem no diário, caracterizada, segundo as palavras de Daniele Aparecida Batista (2010), como delirante e desarticulada. Embora Maura relate fatos de sua vida, retratando aspectos que consideram importantes e decisivos, os quais, segundo ela, culminariam na experiência de sua loucura, acreditamos pontualmente que é impossível descrever as próprias memórias sem cair nas artimanhas do discurso ficcional, pois "sendo a introspecção um ponto nevrálgico desse tipo de narrativa, a sinceridade torna-se questionável" (BATISTA, 2010, p. 12). A partir desse ponto, a pesquisadora considera que Hospício é Deus se caracteriza notavelmente como uma criação literária, em que a autora, por meio dos delírios e das alucinações, encena no universo da escrita a representação da loucura. A respeito disso, ela afirma que: "através da imagem distorcida de um mundo em crise, Hospício é Deus constrói e espelha uma outra realidade articulada segundo uma lógica muito própria, pois sua tessitura dá sentido ao estado patológico da protagonista" (BATISTA, 2010, p. 75). 
Sabemos que Maura não se limitava a descrever as próprias experiências, mas também descrevia as experiências de suas colegas que compartilhavam desse mesmo ambiente hostil, retratando essas mulheres e a difícil convivência com elas. Para a pesquisadora, a rebeldia de Maura é então expressa por intermédio da escrita, em que a autora assume o papel de uma "desequilibrada" com o objetivo de expor o drama das mulheres entre as paredes do hospício. Aqui, fica claro para nós que, em seus escritos, a questão da loucura não está vinculada tão somente à sua experiência no manicômio, mas, igualmente, à experiência da condição da mulher nesse lugar. Em decorrência disso, Daniele Batista (2010) faz suas considerações, ao dizer que o livro de Maura é a prova cabal de sua revolta contra o sistema de tratamento dispensando aos doentes mentais. Assim sendo, a escritora imprime na escrita não somente um desabafo pessoal, mas procura exprimir as dificuldades coletivas, transformando essas experiências em uma obra literária. Em resumo, as reflexões suscitadas nesse trabalho sinalizam que a loucura em Hospício é Deus constitui uma eficiente estratégia discursiva, porquanto, nas palavras de Daniele Batista (2010, p. 100), “a Maura que ali encontramos não é a Maura empírica, mas uma representação literária criada pela autora".

Em sua tese Narrativas e sobreposições: notas sobre Maura Lopes Cançado, Maria Luisa Scaramella (2010), empreende uma interessante pesquisa de campo acerca das narrativas descritas "de e sobre" Maura Lopes Cançado, nos seguintes contextos: uma sendo composta por narrativas orais, em que a pesquisadora, por meio de entrevistas com familiares, conhecidos e amigos da escritora, reuniu fatos e episódios desde a infância das Minas Gerais da década de 1930 até o final dos anos de 1950, período em que Maura esteve inserida nos contextos jornalístico, literário e artístico, na cidade do Rio de Janeiro. De posse dessas informações, reuniu também arquivos da autora, tais como documentos pessoais, cartas, fotos, reportagens e os escritos de seus livros. Por meio da narrativa jurídica, teve acesso aos autos do processo, em que a escritora foi considerada ré por ter assassinado uma paciente em uma de suas internações. Este homicídio foi um episódio trágico ${ }^{23}$ que marcou duramente a vida de Maura.

Tal pesquisa aborda, portanto, as diferentes narrativas em torno da vida da autora, na qual Scaramella (2010) salienta as "tensões e versões" (p. 10) de cada uma delas e, constata que, em se tratando de Maura, não há uma única versão sobre um mesmo fato. Com efeito, a pesquisadora desenvolve uma análise em direção à pluralidade de significados e das diversas

\footnotetext{
${ }^{23}$ Acerca dessa questão, Scaramella relata que teve acesso a doze anos de documentação, de 1972 até 1984, e com isso, pôde examinar os documentos nos quais são registradas as internações nas clínicas psiquiátricas em que a escritora esteve internada.
} 
relações que permeiam a vida e a escrita da autora e descobre que, em todas essas narrativas, ainda que existam pontos de divergências, em comum, há o fato que a imagem de Maura está fortemente associada à imagem da mulher louca. E é a partir dessa confluência de narrativas é que começam as observações quanto às imagens construídas em torno da figura de Maura e a imagem feita pela autora sobre si mesma. Nessa esteira, Scaramella discorre sobre os limites do autobiográfico e do biográfico, destacando a importância dada a essas instâncias que produzem uma verdade, as quais, entretanto, não se sustentam, justamente por serem produzidas em cima de uma subjetividade. Sob essa perspectiva, ela qualifica o livro de Maura como um diário de internação, em que a autora descreve um retrato da loucura a partir das vivências do hospício, nas quais são realçadas as situações de abandono e os tratamentos degradantes que ela e as outras internas sofreram, tais como a exclusão no quarto-forte e as sessões de eletrochoques.

O estudo do diário como mecanismo de sobrevivência também aparece na dissertação de Louise Bastos Corrêa (2013), intitulada A consciência no abismo: uma leitura da obra de Maura Lopes Cançado. Para essa pesquisadora, investigar a vida de Maura seria o mesmo que adentrar em um mundo no qual não encontramos as respostas e constata que, ao fazer a leitura de seu livro somos confrontados com as questões de ordem existencial. Nessa direção, concordamos que o diário da autora convida o leitor à reflexão sobre a dor, a angústia, a violência e o pensar o outro nas suas diferenças. Isso nos permite dizer que, aquele que relata em situações adversas está de alguma forma procurando se salvar de si mesmo e da situação em que se encontra.

Pensemos também nas descrições que Maura faz sobre a vivência no hospício. Segundo Corrêa (2013, p. 64): “a autora usa um 'olhar' mais detalhado e cuidadoso pelo cotidiano do local, observa algumas daquelas pacientes como se estivesse estudando e percebendo características para construir seus personagens”. Ela acrescenta que, escrever para Maura é um ato de resistência, ao mesmo tempo em que é também uma forma de não cair no esquecimento. É evidente, portanto, que na ânsia de escrever sobre seus padecimentos, a escritora não abandona o seu eu olhar crítico. O olhar de Maura é, certamente, a referência dessa realidade e, com isso, ela desenvolve pelo relato, o fazer literário. Por isso, além de conceber também o livro como criação literária, escrever, segundo Corrêa (2013), é o modo pelo qual a autora encontrou para resgatar sua própria identidade desde o momento em que essa fora perdida, quando despiu a roupa no hospício para vestir o uniforme das doentes. Conforme ela atesta, "a entrada no hospício, a nudez imposta nesta passagem para o mundo isento das ameaças do fora, retira também qualquer possibilidade de afirmação ou de 
legitimidade das vozes que de dentro dele emergem" (CORRÊA, 2013, p. 57-58). Diante dessas considerações, o diário de Maura, segundo a pesquisadora, é um dos artifícios para conseguir viver e defende que a Literatura tem também como premissa corrente, salvar vidas. Ela pondera que, ainda que a escrita de Maura tenha o compromisso de compor uma verdade, acerca da realidade de sua vida e de suas experiências no manicômio, é um erro apreendermos toda a sua narrativa como sendo um retrato fiel da realidade.

Em Literatura e loucura: a transcendência pela palavra, Celia Musilli (2014) analisa, nessa dissertação, a linguagem utilizada por Maura Lopes Cançado, para refletir sobre a relação entre literatura e loucura à luz de uma abordagem surrealista ${ }^{24}$. Esse estudo focaliza uma produção estética submetida a certa tensão, entre a lucidez e a insanidade, que segundo Musilli, impossibilita demarcar limites para classificar a escrita do diário tão somente como mero registro desarticulado e/ou de desabafo. Para essa pesquisadora, a loucura em Maura é o principal elemento para a criação de sua obra, cuja condição permite dar vazão à sua criatividade, a qual é refletida por meio da escrita. Entretanto, mesmo apreendendo Hospício é Deus como uma obra que se desenvolve entre realidade e ficção, Musilli considera o diário, acima de tudo, um relato realista, no qual Maura utiliza-se de estratégias para divulgar seu livro. A sua participação no Suplemento Dominical do Jornal do Brasil, com a publicação de contos, secunda uma dessas estratégias, na ocasião em que ela se serve da condição de autora para ir além dos muros do hospício e, assim, poder legitimar sua fala dentro de uma sociedade que estigmatiza a loucura, mas que a enaltece como escritora. Pelas palavras de Musilli (2014, 32), no relato de Maura encontramos "o devaneio, a fantasia, a criação, mas com detalhes que não deixam dúvidas sobre a autenticidade de muitas passagens, levando-se em conta, inclusive, a crueldade de alguns métodos de tratamento". Corroborando então com o seu pensamento, o grande mérito de Maura Lopes Cançado é precisamente transformar a atividade de escrita numa linguagem literária, em virtude de sua força narrativa com que emprega as palavras e organiza a experiência. Ela complementa enfatizando que, para além do caráter literário de sua escrita, Maura faz denúncia do sistema psiquiátrico opressor que subjuga e oprime os doentes mentais.

A bem da verdade, ao lermos o diário de Maura, sabemos, de fato, que ela revela os componentes de uma situação dramática em que enfrentava os sistemas psiquiátricos no

\footnotetext{
${ }^{24}$ Sob essa abordagem, a análise de Musilli (2014, p. 97) considera que o diário de Maura é definido como uma poética da existência em virtude da relação entre arte e vida, um dos pressupostos do surrealismo. Trata-se de uma postura da expressividade espontânea, no que diz respeito à reação automática, à capacidade inventiva do artista de registrar tudo aquilo que lhe vier à mente sem se preocupar com uma lógica dominante.
} 
Brasil nas décadas de 50 e 60 do século XX. O seu relato, nesse período, situa precisamente a obra como documento sobre a história da assistência em saúde mental. Logo, estando imersa nesse cenário, a autora-personagem cria uma narrativa para deflagrar suas emoções e delírios, como também procura externar a sua inconformação com os ditames sociais estabelecidos. Nesse sentido, ao abordar o surrealismo tanto no diário como nos contos de Maura, Musilli (2014) centra-se na imagem dos olhos da narradora e utiliza-se da leitura que procura legitimar o discurso do louco para resgatar a voz dos historicamente excluídos. Ela, então, observa que em Maura, "ver detalhadamente para escrever é um recurso que utiliza para passar as minúcias do cotidiano para o diário, como se ligasse no hospício uma câmera secreta que capta os acontecimentos" (MUSILLI, 2014, p. 76). Para a pesquisadora, o diário caracteriza-se, assim, como uma autorrepresentação da louca e sua análise traz à tona uma reflexão que alia loucura e resistência, sendo fortemente crítica à escrita do diário como obra puramente ficcional, colocando-se como permanente defensora do diário como um registro em que são expressas as verdades que a sociedade insiste em omitir.

A dissertação intitulada Loucura e gênero: uma análise da escrita autobiográfica de Maura Lopes Cançado, escrita por Leísa Ferreira Amaral Gomes (2014) no campo da Psicologia Social Crítica, apresenta-nos o discurso da loucura presente em Hospício é Deus, livro-denúncia, como ela nomina, destacando as questões relacionadas à loucura e ao gênero. Ao realizar tal estudo, a pesquisadora articula de forma crítica um olhar para a situação de exclusão social da mulher e ressalta o como essa exclusão delineou historicamente as experiências das mulheres que foram internadas em hospitais psiquiátricos. Ela então dimensiona e reflete o conflito dessas vozes que, durante séculos, foram silenciadas e invisibilizadas.

Aqui, a questão da identidade é também colocada em foco, visto que como mulher escritora e jornalista, a escrita de Maura Lopes Cançado fala a partir de um lugar e de uma posição que caracteriza o seu discurso como uma experiência-denúncia. Conforme situa Gomes (2014, p. 144), "Maura se movimentou em um contexto de gênero coercitivo e restritivos conceitos normativos de gênero acabaram por permear seu discurso". Claramente podemos dizer que, Maura é a porta voz dessas mulheres que, ao longo da história, ficaram encerradas entre as paredes da solidão, e, por esse motivo, ela constrói uma memória coletiva a respeito da condição feminina dentro desse espaço.

Em Maura, louca? Não, "Cançada": os desatinos existenciais de uma "hipermulher" nas décadas de 1940/1950, dissertação apresentada na área dos estudos da Psicologia Clínica e Cultura, Vânia Romão de Souza (2014) pensa a obra Hospício é Deus, a partir de três pontos 
de foco: a primeira análise faz reportar aos possíveis diálogos entre as questões de gênero e saúde mental; a segunda parte analisa a biografia de Maura, junto ao momento histórico e social, com o fim de compreender os dilemas e conflitos de sua vida inscritos no diário; e, por último, desenvolve duas análises de Hospício é Deus, buscando entender aspectos importantes que particularizam a obra da autora. Neste caso específico, sua análise focaliza os objetos ${ }^{25}$ que a escritora desenvolve em seu diário e, em seguida, faz um levantamento de cada um desses temas e categorias. Segundo Souza (2014, p. 99), “o intuito é apontar quais preocupações eram recorrentes na vida da escritora e deixar evidente o descompasso entre o seu modo de ser/viver e os ideais de mulher da época".

A partir dessa minuciosa investigação, a pesquisadora aponta que ao final desses estudos, o sofrimento psíquico emerge como significante central em Hospício é Deus, em razão da não adequação de Maura dentro dos valores e papéis sociais estabelecidos à época. Ao mesmo tempo, Souza (2014, p. 102) ressalta que, por ser a narrativa de Maura uma atividade "poética, concisa e também política", ela situa a autora como sendo uma intelectual visionária, cuja interpretação da realidade se faz através da problematização dos valores patriarcais enquanto discurso normativo. Seguindo essa linha de raciocínio, é forçoso reconhecer Maura como uma escritora vanguardista e política e, nesse sentido, Souza lamenta o fato de que, ainda hoje, muitas pessoas que trabalham com a saúde mental, precisamente as pessoas associadas ao movimento da reforma psiquiátrica, desconhecerem a vida e a obra de Maura. Assim, ela se refere ao diário como uma experiência subjetiva, cujo trabalho com a escrita se realiza, principalmente, mediante as relações pessoais vivenciadas pela autora ao longo de sua vida. Em suas palavras, a narrativa de Maura "demonstra o peso do senso comum e o poder do discurso social que habita o imaginário, a fala e a escrita das mulheres" (SOUZA, 2014, p. 128).

Na dissertação Literatura e loucura: a carnalidade da loucura de Maura Lopes Cançado em Hospício é Deus, Marcia Moreira Custódio (2014) explica como na escrita da autora a ficção pode surgir na vontade de uma verdade sincera. Por ser um compilado de memória, diário e autobiografia, e onde as dimensões do real e do ficcional se confundem, Hospício é Deus, para ela, se aproximaria do conceito de autoficção, de Serge Doubrovsky, criador do termo. A premissa desse conceito formula que a identidade entre autor, narrador e personagem é a mesma, porém, os eventos narrados são ficcionais, mesmo que no texto o

25 A saber, os objetos que foram levantados nessa pesquisa: "Relações pessoais; Descrições/Avaliações de si; Instituição; Doença/Loucura/Diagnósticos; Escrita; Sexualidade; Moral; Ações, pensamentos violentos; Desejos; Jornal” (SOUZA, 2014, p. 103). 
autor seja o personagem principal. Foi tendo isso em vista que, Custódio (2014, p. 52) fez a observação de que mesmo existindo elementos referenciais, há, em Hospício é Deus, verdades que podem ser manipuláveis, de acordo com o interesse da autora. Assim, ao elucidar e formalizar essa tensão entre real e ficcional, afirmando que a narrativa biográfica de Maura apresenta um eu em constante deslocamento, a pesquisadora concebe, pois, Hospício é Deus como um espaço de autocriação, onde a voz da loucura consegue transpor os limites sociais e culturais. Em suas palavras: "na autoficção, a intensidade narrativa revela-se diferente da história vivida, na medida em que ocorre a transposição do eu no texto por meio da escrita que, por sua vez, será afetada pelas marcas estéticas da criação" (CUSTÓDIO, 2014, p. 52).

Consequentemente, mesmo figurando o diário como matéria ficcional, Custódio (2014) não ignora as verdades contidas ali. O diário de Maura serve como estratégia de sobrevivência e denúncia (p. 81), porém, ela considera que no momento em que a subjetividade é manifesta pela escrita, um outro eu é recriado: “o que se vislumbra no diário é uma Maura ficcional, tentando se afirmar e exprimir-se a um leitor. Um retrato que foge à originalidade, pintado com a linguagem literária" (CUSTÓDIO, 2014, p. 45). Temos, então, segundo a estudiosa, uma experiência subjetiva fortemente marcada pela violência, a qual se configura, por meio da palavra escrita, em atividade de expressão estética transgressiva.

Fundamentada nessas observações, para ela, o livro de Maura não se aplica à definição de autobiografia de Philippe Lejeune. Em seu estudo, o autor considera que a autobiografia é uma narrativa em prosa "que uma pessoa real faz de sua própria existência, quando focaliza sua história individual, em particular a história de sua personalidade" (LEJEUNE, 2008, p. 14). É, preciso, portanto, uma espécie de garantia do que está sendo dito no texto, seja de fato uma história real. Por isso, para o crítico francês, a autobiografia pressupõe que a identidade entre autor, narrador e personagem seja idêntica, sendo o nome próprio o elemento essencial para o pacto autobiográfico com o leitor. Doubrovsky, por sua vez, direcionou sua atenção à história ficcional. Mesmo se apresentando como narrador e personagem, o autor enfatiza que a história contada por ele não é real. Ele explicita essa questão ao leitor ${ }^{26}$. Contudo, Custódio considera que Hospício é Deus não é caracterizado como autobiografia, porque, de acordo

\footnotetext{
${ }^{26}$ Num pequeno ensaio paralelo ao seu romance intitulado Fils, em que o narrador e personagem são o próprio Doubrovsky, o autor afirma que os eventos narrados são fictícios. Acerca de uma das fases em que procura definir melhor o conceito de autoficção, o autor diz assim: autoficção é "uma história que, qualquer que seja o acúmulo de referências e sua precisão, nunca aconteceu na realidade, e cujo único lugar real é o discurso em que ela se desenrola" (DOUBROVSKY, 1988, p. 73 apud FAEDRICH, 2016, p. 36).
} 
com ela, tal gênero se compromete em dizer a verdade daquele que escreve, o que, na prática, seria uma ilusão, considerando que toda narrativa é mediada pelos artifícios literários.

O fato é que toda narrativa das escritas sobre si implica reinventar uma nova história. Um escritor que tem o sincero desejo de registrar o vivido na forma de escrita pode tomar a palavra para fazer esse percurso, ainda que ele tenha de organizar esse material e dar-lhe forma. O próprio Lejeune (2008, p. 66) reconhece essa ambiguidade entre o real e o imaginário, reafirmando o caráter literário da escrita autobiográfica: "Dizer a verdade sobre si, se constituir em sujeito pleno, trata-se de um imaginário. Mas, por mais que a autobiografia seja impossível, isso não a impede de existir”"

O que determinam exatamente o que seja autobiografia e autoficção ainda é motivo de controversas entre os críticos. Anna Faedrich (2016), no artigo intitulado "Autoficção: um percurso teórico", descreve o processo pelo qual a autoficção é esboçada desde o momento de sua concepção, enfatizando que muitos estudiosos se apropriam do termo de forma equivocada. Ela diz:

\begin{abstract}
Afirmar que autoficção é o exercício literário em que o autor se transforma em personagem do seu romance, misturando realidade e ficção, é condição necessária, mas não suficiente. Para evitar confusões teóricas, é fundamental um consenso mínimo do que seja literatura e ficção. Ademais, é preciso considerar diferentes aspectos da escrita autoficcional: uma prática literária contemporânea de ficcionalização de si, em que o autor estabelece um pacto ambíguo com o leitor, ao eliminar a linha divisória entre fato/ficção, verdade/mentira, real/imaginário, vida/obra, etc.; [...] o movimento da autoficção, que é da obra de arte para a vida - e não da vida para a obra, como na autobiografia -, potencializando o texto enquanto linguagem criadora (FAEDRICH, 2016, p. 44, destaque da autora).
\end{abstract}

É sob essa perspectiva que examinamos a autobiografia: o movimento da vida para a obra e o compromisso com a verdade contida na escrita, por meio do pacto autobiográfico, pois a obra de Maura Lopes Cançado propõe a fornecer informações sobre a realidade externa ao texto. A autora trata da percepção de sua vida em momento de crise. Escrever para ela, é relembrar eventos que foram traçados para a mulher de seu tempo e reconstruir sua identidade desde o momento em que esta fora estilhaçada por uma educação castradora, que coloca para as mulheres as experiências da aceitação, submissão e passividade. Sua escrita ganha vida no instante em que se rebela contra todo o sistema que a colocou na condição de louca.

Em sua dissertação intitulada $A$ sofredora do ver e a urgência da escrita: a poética de Maura Lopes Cançado, Rosângela Lopes da Silva (2017) busca abordar uma "poética da dor e do ver", como ela apresenta, pela representação das imagens visuais e simbólicas que, 
segundo ela, são recorrentes nas obras da escritora. E a partir disso, destaca a relação entre loucura, literatura e linguagem, com o propósito de investigar como a escrita de Maura é produzida dentro de situações que ameaçam a subjetividade do eu. Nesse percurso, ela explica que, por ser a escrita de Maura uma forma de resistência que nasce em meio às situações de opressão, as quais, por seu turno, insistem em reafirmar os mecanismos de silenciamento contra aqueles que insurgem contra as normas sociais e políticas dominantes, a autoexpressão da autora "é representada em sua escrita por meio de um estilo que apela para o visual quando o dizível já não consegue expressar a profundidade do vivido" (SILVA, 2017, p. 122). Isso porque o ato de escrever sobre si mesma e sobre a realidade do hospício foi o modo pelo qual ela encontrou para lidar com a dor e as angústias.

Sendo assim, nada mais natural que a imagem do olhar como um ato reflexivo, que, acima de tudo, alcançou em seus escritos uma dimensão filosófica, original e profunda acerca das condições dos hospitais psiquiátricos da época. E mais do que isso: a escritora confere existência às personagens que compartilhavam desse espaço, tais como médicos, enfermeiras e guardas, adotando uma postura crítica em relação aos papéis de cada uma delas. E quanto às internas, uma vez mais percebemos como suas vidas cerceadas simbolizam uma (re)leitura desse lugar de ausências e negação de subjetividades. Conforme lembra Rosângela Silva (2017, p. 16): “o ver na de obra de Cançado é, então, recurso literário e linguagem transgressiva. Ele, paradoxalmente, é dor/silêncio e necessidade de dizer/palavra". Assim, com sua expressão de verdade geral, Hospício é Deus, para essa pesquisadora, é traduzido como um quadro em que vemos as memórias que refletem o individual e o coletivo. E tal como um quadro, o diário da autora é claramente destinado a um público-alvo (SILVA, 2017, p. 64), o que o caracteriza como uma obra exemplarmente de caráter político e social.

Retratos em abismo: poses e posses do diário de Maura Lopes Cançado, dissertação de Anna Flávia Dias Salles (2017), tem como intenção destacar os aspectos da vida e obra da escritora a partir da análise dos retratos feitos sobre ela, compreendidos entre os anos de 1954 a 2015. Acerca desse estudo, a pesquisadora verificou que tanto os retratos jornalísticos como os retratos de crítica (artigos, menções em obras e estudos acadêmicos) foram muitas vezes pautados na condição psicopatológica da autora, antes mesmo de ser reconhecida como escritora. Assim, diferentemente das abordagens centradas, predominantemente, no sofrimento psíquico de Maura, Salles coloca em foco as estratégias literárias utilizadas no diário, e, com isso, ela procura demonstrar como, pela escrita, a autora consegue desenvolver a narrativa da loucura. 
Um dos exemplos interessantes que a estudiosa toma nota em sua pesquisa, acerca desses procedimentos literários, é sobre o conceito de autorretrato e retrato literário em algumas passagens de Hospício é Deus. Para isso, ela toma como referência o pensamento de Michel Beaujour, cuja obra Miroirs d'encrerhétorique de l'autoportrait, publicada em 1980, o autor afirma que o autorretrato se distingue da autobiografia. Dessa leitura, Salles (2017) ressalta um dos aspectos discutidos por ele acerca desses termos, definindo a autora como sendo autorretratista literária, pois de acordo com ela, sua narrativa, "diferentemente do relato sucessivo que caracteriza a autobiografia, o autorretrato configura-se como montagem de migalhas, uma escrita que se faz à borda do vazio, sem um eixo cronológico organizador" (BEAUJOUR 1980, p. 9 apud SALLES, 2017, p. 88). Essa definição se explica em razão dos fragmentos descontínuos, trechos, poemas, citações de personalidades que a autora utiliza na composição de seu diário, construindo, a sua maneira, um mosaico de memórias. E assim, ao caracterizá-la como autorretratista, a pesquisadora leva em conta a capacidade inventiva da escrita de Maura, na medida em que a autora, ao buscar o "quem eu sou" pela escrita, "encontra, no espelho linguajeiro, sua imagem borrada, manchada, tingida pela tradição cultural a que pertence: miroirs d'encre, espelhos de tinta, espelhos borrados" (BEAUJOUR, 1980 apud SALLES, 2017, p. 88). Isto é, ainda que o autorretratista deseje compor um retrato fiel de si mesmo, tal imagem projetada no texto será reproduzida em cima de fragmentos e distorções ${ }^{27}$.

Essas questões nos levam a crer que a narrativa literária de Maura é certamente construída sob a presença de um leitor. Partindo da análise de Salles (2017), isso se registra quando observamos que a autora, ao projetar sua imagem no texto, lança mão de recursos para delinear e aperfeiçoar seu retrato de maneira que essa postura não corrobora com a típica atribuição do diário como gênero confessional. A respeito disso, Salles comenta sobre a noção de "pose":

Mesmo quando fala de sua intimidade, observa Ávila, o escritor escreve em "pose". Nessas "poses" é possível identificar o manejo que faz da própria imagem tendo em vista uma certa recepção, ainda que ilusória ou inventada ou mesmo que apenas intimamente esperada numa possível posteridade (ÁVILA, 2016, p. 12 apud SALLES, 2017, p. 78).

${ }^{27}$ Partindo da formulação do ensaísta francês, Salles emprega a metáfora do espelho manchado quando diz que ao refletir a própria imagem na escrita, o autor não consegue impedir que essa imagem, pintada com as palavras, seja de alguma forma, borrada, manchada. 
Não podemos ignorar, portanto, que o livro da autora é também construído em virtude de suas relações de trabalho e amizades, as quais a vinculavam com o Suplemento Dominical do Jornal do Brasil.

Outro ponto de reflexão desenvolvido por Salles (2017), em torno da produção de Maura, é a de retratista literária. Objetos, pessoas, diálogos, descrição do espaço e acontecimentos do manicômio são colocados em cena pela escritora, que, à maneira de um pintor, pinta e registra aquilo que não consegue escapar a seus olhos. O cenário do hospício passa a ser então um grande objeto de observação para essa retratista que, pela escrita, figura um modo de ser e estar no mundo. Nessa direção, sua pesquisa abrange o diário de Maura como literatura autobiográfica, passando pelas definições de autorretratos e retratos literários, em que todas essas formas, evidenciam a autonomia da criação literária em relação à biografia (SALLES, 2017, p. 98).

Propomo-nos, assim, a conhecer, de forma sucinta, como cada pesquisadora pensou e categorizou a obra Hospício é Deus. Em resumo, a reflexão sobre o diário como estratégia literária fez-se majoritária, em razão do caráter artificial que o discurso de primeira pessoa comporta, cuidando de distinguir o eu da autora do eu da personagem. Porém, notamos que há pesquisas que concebem o diário de Maura não apenas como um discurso literário, mas destacam, predominantemente, o caráter documental e histórico de sua narrativa.

Significativamente, uma certeza que se fortalece aos nos depararmos com a escrita de si, é a consciência de que ela exprime esse caráter ambíguo entre realidade e imaginação. Sobretudo, é preciso ressaltar que toda escrita literária, seja qual for o gênero, prevê um encontro com a verdade e a mentira. Em nosso recorte, da fortuna crítica selecionada, percebemos que essa tensão entre literatura e vida interfere sensivelmente em dois pontos vitais discutidas dentro do panorama das escritas do eu. Veremos, no próximo capítulo, na seção intitulada "Os limites entre arte e vida: autobiografia, memória e diário", que Maura Lopes Cançado, ainda que tenha o desejo de ser sincera na escrita de seu diário, relatando suas dores, angústias, alegrias e anseios, a própria memória irá romper com esse desejo, uma vez que concluímos que "há sempre interferência da imaginação na identidade narrativa construída em um texto biográfico, por mais "real" e verificável que [ela] queira ser" (MACEDO, 2019, s/p, destaque meu). Isso significa dizer que toda e qualquer escrita sobre o eu certamente trará em sua composição discursiva elementos ficcionais, pois a memória nos oferece, quase sempre, lacunas ou distorções que não poderão ser preenchidas em sua 
totalidade. A mesma oposição acontece em um texto ficcional. No romance, por exemplo, o autor, em algum momento, consciente ou inconsciente, pode revelar verdades sobre si mesmo.

Passemos, então, à consideração particular da loucura nesse contexto das escritas de si, buscando compreender como a autora desenvolve a narrativa da loucura no exercício de sua escrita. 


\section{A LOUCURA E A ESCRITA DE SI}

E por mais que eu grite ninguém escutará (CANÇADO, 2016a, p. 77).

Embora o diário seja o registro das memórias e dos fatos de si, ele também encerra um tipo particular de narrativa ficcional, pois o sujeito que o escreve está reconstruindo a experiência do passado. A esse respeito, Philippe Lejeune (2008, p. 298) tece importante reflexão: "Manter um diário é surfar no tempo. [...] o próprio diarista é levado pelo movimento que vai esculpindo, acompanhando e realçando algumas de suas linhas e vetores, transformando em dança essa inelutável deriva".

Assim, muito mais que uma escrita íntima o diário é um instrumento que permite pensar e construir a própria identidade, seja através da apreensão dos conflitos íntimos expressos na escrita, seja por meio da evasão da realidade como forma de sobrevivência.

Levando em consideração a narrativa do diário, na seção que compõe este capítulo, "Os limites entre arte e vida", refletiremos acerca do objeto diário, da autobiografia e das memórias. Evidentemente, com a publicação de Hospício é Deus, estamos diante de um aspecto importante: esse diário trata-se, portanto, de uma construção - assim como o é a poesia -, o que nos leva a concluir que a arte é um objeto intencional. Mas antes de darmos início a essa reflexão, tomamos como ponto de partida a questão do autor biográfico na escrita sobre o eu. Sendo assim, o pano de fundo que iremos traçar na próxima seção, "A escrita de si e o autor empírico", é justamente sobre esse eu literário que enuncia um eu. Finalmente, ler com a perspectiva de que o que está sendo dito é, de fato, a história do que realmente aconteceu à autora, especialmente em se tratando de uma confissão da loucura, é meditar sobre o espaço da escrita que permite reescrever a história de uma vida, tal como veremos na última seção "A loucura como forma de narrar a experiência".

\subsection{A ESCRITA DE SI E O AUTOR EMPÍRICO}

Aqui estou de novo nesta "cidade triste", é daqui que escrevo (CANÇADO, 2016a, p. $30)$.

O gênero confessional compreende, na literatura, a escrita de si, que abarca diários, correspondências, memórias, ensaios e autobiografias, entre outros gêneros, e cuja prática de 
escrita remonta à da Antiguidade ${ }^{28}$. Contudo, a consciência de um eu que narra em primeira pessoa só teve seu papel de destaque no século XVIII quando, no momento da ascensão da sociedade burguesa e da difusão da noção de indivíduo no Ocidente, houve a relação desse indivíduo moderno com seus documentos (GOMES, 2004, p. 11).

Do mesmo cenário, Leonor Arfuch (2010, p. 35) observa que existe certo consenso entre os estudiosos sobre Confissões, a obra de Jean-Jacques Rousseau, publicada em 1782, ser o marco inicial dos gêneros literários autobiográficos, caracterizando, desse modo, a especificidade de tais gêneros ${ }^{29}$. Destaca que ao mesmo tempo em que Rousseau consegue, por meio de sua obra, dar visibilidade à voz interior, também "colocava em cena, de modo emblemático, aquele enfrentamento do "eu contra os outros"” (ARFUCH, 2010, p. 49). Com efeito, é também no mesmo século que tais escritos sobre o eu ganhariam não só contornos literários, como se constituiriam num espaço no qual o sujeito pudesse realizar o exercício da autorreflexão. Tal exercício contribuiria na consolidação de individualidade, cuja implicação marcaria então a noção de indivíduo como sendo um dos traços típicos do Ocidente e, consequentemente, a noção de sujeito burguês, centrado na figura do eu, delimitaria a dualidade com as noções de público/privado, sentimento/razão, corpo/espírito e homem/mulher (ARFUCH, 2010, p. 36). Essas dicotomias marcariam, segundo a autora, a sensibilidade do mundo burguês.

Conforme Angela de Castro Gomes (2004, p. 11), em seu texto "Escrita de si, escrita da História", desde então, escritores e, mesmo as pessoas "comuns", passaram a produzir, deliberadamente, uma memória de si e a torná-las públicas, como é o caso de alguns escritores que cultivaram a escrita de diários ou cartas como laboratório do processo de criação para as suas obras. Como exemplos desses registros temos, no Brasil, o Diário completo, de Lúcio

\footnotetext{
${ }^{28}$ Michel Foucault (1992) em seu texto "A escrita de si”, ao falar sobre a constituição do eu a partir do exercício da escrita, retorna até a Antiguidade Greco-romana para compreender os mecanismos de subjetivação do sujeito. Em linhas gerais, o que Foucault notou nesses estudos é que a escrita de si está inserida em uma prática de exame de consciência, i.e., tal prática permite ao indivíduo organizar os pensamentos e a refletir sobre os atos cotidianos. Não se trata, nesse período, de um exame confessional, mas de reavivar leituras e conversas significativas, as quais poderão auxiliar no exercício de autoanálise.

${ }^{29}$ Como vimos, desde a Antiguidade a escrita de si já existia - não no campo da arte literária, mas como uma tradição já estabelecida entre aqueles que desejassem fazer exame de consciência por meio da escrita. Já nos primeiros séculos da era cristã, tal prática era então incentivada pelas religiões, e muitos padres católicos, por exemplo, seguiam essa tradição confessional (HERVOT \& SAVIETTO, 2009). Em face dessa realidade, diversos estudiosos consideram que as Confissões de Santo Agostinho (séc. IV d.C.) é reconhecida como o primeiro referente de uma escrita autobiográfica da história. Entretanto, a autobiografia, no sentido moderno da palavra, passa a receber conotação literária no século XVIII com as Confissões de Rousseau, no qual a figura do "eu" assume uma posição de destaque com a ascensão da burguesia.
} 
Cardoso, as Cartas, de Caio Fernando de Abreu e o volume que reúne cartas de Clarice Lispector, intitulado Correspondências/Clarice Lispector.

Para Gomes (2004), o interesse pela leitura de cunho confessional tem sido crescente nos últimos anos, seja porque os leitores anseiam conhecer a vida e o contexto histórico de uma personalidade - na esfera política brasileira o caso emblemático é Anos tormentosos: correspondência da prisão (1936-1945), cuja obra, reunida em três volumes, compõe as 900 cartas do prisioneiro político Luís Carlos Prestes (2004, p. 8); ou porque através da narrativa de testemunho procuram um meio de obter a ligação entre a figura do herói e os sentimentos que os une (2004, p. 19, destaque meu) - já que os registros subjetivos são aqueles que mais se aproximam do leitor, pois estão centrados na figura do sujeito.

No entanto, embora tais escritos integrem um contexto particular de prática cultural no qual a consciência de sujeito moderno busca, por meio do exercício da escrita, pensar a própria identidade -, cabe aqui considerar os estudos de Paulo Sérgio de Vasconcellos (2016) sobre a forma como os antigos viam a relação entre o que se expressava em primeira pessoa na poesia amorosa romana e o autor empírico ${ }^{30}$. Considerando que o leitor comum há séculos costuma associar elementos do texto com a vida de seu autor, sobretudo quando a escrita se faz em primeira pessoa, as considerações de Vasconcellos acerca da recepção de leitura dos antigos romanos colaborarão na compreensão entre dicotomia vida/arte. Por meio dessa análise investigaremos, no terceiro capítulo desta dissertação, os mecanismos narrativos da escrita de si em Maura Lopes Cançado.

Nesse sentido, a fim de elucidar melhor a questão da diferença entre autor empírico e persona poética, Vasconcellos (2016) toma como reflexão inicial a consciência lírica moderna de Fernando Pessoa, pois, de fato, na obra do poeta, o fenômeno da heteronímia constitui um modelo singular de poesia escrita em primeira pessoa. Assim, em sua obra, o poeta "se divide em vários eus poéticos e lhes dá expressão singular" (VASCONCELLOS, 2016, p. 12). O autor delimita essa experiência como sendo um ato de "despersonalização" - como o próprio poeta já definira -, ou seja, “o 'eu' que toma a palavra remete a vários enunciadores, não apenas àquele que o leitor tende a identificar com o autor de carne e osso" (VASCONCELLOS, 2016, p. 11). Contudo, a questão se complica quando se fala na

\footnotetext{
${ }^{30}$ No livro Persona poética e autor empírico (2016), Paulo Sérgio de Vasconcellos se debruça sobre a relação entre persona poética e autor empírico nos escritos literários da Antiguidade Clássica. $\mathrm{O}$ foco desse trabalho é a análise da poesia amorosa romana escrita em primeira pessoa, visando compreender a sua produção e recepção à época. Para isso, o autor se concentra em Catulo, e nos poetas elegíacos, e também analisa textos de Horácio, Virgílio, entre outros. Em consonância com esse percurso, acerca da reflexão sobre o que um texto nos revela sobre quem escreve, Vasconcellos igualmente discorre sobre textos de filosofia e retórica, examinando passagens de autores como Sêneca, Plínio e Apuleio.
} 
produção de Fernando Pessoa "ele-mesmo", i.e., quando seus poemas são assinados em seu próprio nome: seria então, Fernando Pessoa uma persona assim como Alberto Caeiro, Ricardo Reis ou Álvares de Campos na poesia?

Michel Foucault (1992) em sua notória conferência “o que é um autor?”, apresentada em fevereiro de 1969, à Societé Française de Philosophie (Sociedade Francesa de Filosofia), ao discorrer sobre a relação do texto com o autor defende que à escrita contemporânea há o desaparecimento do sujeito que escreve. Se com os antigos gregos a escrita conferia imortalidade ao autor - exemplos clássicos são as narrativas de cunho épico -, na modernidade, por sua vez, essa relação se inverte, pois o texto resultaria no apagamento do autor. Isso significa dizer que a escrita está dissociada do autor empírico de modo que, tudo que se refere aos traços da personalidade do autor são materializados para uma experiênciaescrita, a qual difere da experiência real daquele que escreve e, que, portanto, não faz reportar ao plano da subjetividade. É, com efeito, o que Foucault assinala como sendo a "funçãoautor", cujo conceito repousa na distância entre o autor empírico e um conjunto de descrições sobre esse sujeito que constrói o discurso. Nas palavras do filósofo: "a função autor é, assim, característica do modo de existência, de circulação e de funcionamento de alguns discursos no interior de uma sociedade" (FOUCAULT, 1992, p. 46).

Dessa leitura, o autor é, portanto, um organizador do discurso, tal qual demonstrado no célebre poema "Autopsicografia" de Fernando Pessoa (1976). O autor declara ser todo poeta imbuído de certa capacidade de despersonalização, como é demonstrado nos seguintes versos: "O poeta é um fingidor. / Finge tão completamente / Que chega a fingir que é dor / A dor que deveras sente" (PESSOA, 1976, p. 201).

Em face de tal discurso, T. S. Eliot (1989) considera que as emoções expressas na poesia $^{31}$ não serão as mesmas do poeta. Deste modo, ainda que a "dor" manifesta no poema revele a experiência sensorial do poeta, esse sentimento é, no plano da poesia, traduzido em

\footnotetext{
${ }^{31}$ A título de nota, lembremos que em Literatura, e, por sua vez, no estudo desta dissertação, a poesia apreende um conceito amplo, qual seja, a de criar, a de fantasiar. Em alemão, por exemplo, a palavra para poeta é Dichter, cujo sentido é a do poeta como criador (FREUD, 2018). Assim sendo, a poesia não está associada tão somente à escrita disposta em versos, mas com a capacidade de criar - e aqui podemos incluir também os escritores, os romancistas, os contistas e outros. Consideremos ainda o emprego de "poeta" em Aristóteles, no seu tratado de poesia e de arte intitulado Poética (1973), no qual o autor expressa na palavra "poeta" a noção de sujeito que não fabula versos, mas que é capaz de transformar o não ocorrido em "realidade": "[...] o poeta deve ser mais fabulador que versificador; porque ele é poeta pela imitação e porque imita ações. E ainda que lhe aconteça fazer uso de sucessos reais, nem por isso deixa de ser poeta, pois nada impede que algumas das coisas que realmente acontecem sejam, por natureza, verossímeis e possíveis e, por isso mesmo, venha o poeta a ser o autor delas" (ARISTÓTELES, 1973, p. 451).
} 
uma experiência outra, que advém da organização de um espaço que experimenta a linguagem e que não pertence à esfera do real, mas, imprime ao leitor emoções e impressões como se fossem sentidas de fato. Essas experiências, de acordo com Eliot, organizariam a tensão entre o real e o ficcional, transformando essa dor em uma composição estética. Por esta via, essa dor "torna-se uma dor fingida, modelada pelo discurso poético" (VASCONCELLOS, 2016, p. 13), como o próprio poeta já enunciara no trocadilho "fingidor", "finge dor".

Nesse ensaio "Tradição e talento individual" (1989), publicado pela primeira vez em 1917, Eliot esboça uma concepção acerca da objetividade da arte com o propósito de compreender o comportamento do texto literário em relação às experiências do autor. Segundo Eliot, para que a experiência da escrita da poesia se torne objeto de arte é necessário considerar, em princípio, três passos, a saber: ao poeta, cabe buscar a consciência do passado, inscrita na gênese de sua geração; em segundo, apreender a tradição literária construída pelos escritores antigos - tais como Homero ou Shakespeare; para, ao longo de sua trajetória como artista, desenvolver essas consciências haja vista que "nenhum poeta, nenhum artista, tem sua significação completa sozinho" (ELIOT, 1989, p. 39). Dentre essas condições, é também necessário que ocorra uma entrega por parte do escritor no processo de sua escrita a fim de sacrificar-se em prol da arte, já que o texto poético pode prescindir de quaisquer emoções. Quando isto ocorre, há, de acordo com autor, uma contínua "extinção da personalidade" (ELIOT, 1989, p. 42) o que definiria o conceito de despersonalização. É por meio deste conceito que a arte se aproxima do estatuto de ciência, em que a expressão da personalidade se transformaria em sabedoria técnica.

Com o intuito de exemplificar melhor a teoria impessoal da poesia, Eliot (1989, p. 43) estabelece uma relação do poema com o seu autor por meio da analogia do catalizador. Numa câmara, ao misturar dois gases de oxigênio e dióxido de enxofre na presença de uma partícula de platina, forma-se ácido sulfúrico. Porém, este novo composto formado não contém qualquer indício de platina, a qual se manifesta inalterada. Sendo assim, o fragmento de platina é comparado com a mente do poeta, para quem a personalidade não está presente, i.e., para além dos sentimentos pessoais, o poeta dispõe de várias combinações de emoções e elementos diversos, transformando sua criação em obra de arte. Nesses termos, ainda que a mente seja o meio pela qual o poeta constrói sua composição artística, ela não é o único meio que organiza a sua experiência e tampouco se deixará conduzir pelos seus sentimentos; o verdadeiro poeta, para o autor, consegue de alguma forma separar suas emoções da mente que cria; e a mente, por sua vez, saberá elaborar os sentimentos e a transformá-los em matéria artística. Não há, portanto, na criação da obra de arte literária, a valorização da personalidade. 
Diante desse contexto, a consciência de um outro "eu" na poesia subjetiva, diferente do "eu" do autor empírico, fez ressurgir, por volta dos anos 1920, nos Estados Unidos, uma nova linha crítica de pensamento que nega a importância da biografia do autor com a sua obra: a "Nova Crítica" americana (New Criticism ${ }^{32}$ ). Essa corrente teórica ${ }^{33}$, segundo Vasconcellos (2016), defende que a poesia amorosa e erótica romana são puramente ficcionais ${ }^{34}$, excluindo a ideia de intenção do autor. Assim, o "eu" poético, usando a metáfora que Fernando Pessoa faz com o teatro, é revestido de uma máscara a qual expressa emoções e sentimentos que não é a do autor que escreve, o autor empírico. Se assim for, esses sentimentos já não serão os mesmos de seu autor, mas transformados em outra coisa na obra de arte (VASCONCELLOS, 2016, p. 14).

Em consonância com o pensamento da Nova Crítica, Roger Chartier (2012), ao tratar sobre a definição da "função-autor", remete-nos à obra de ficção "Borges e eu" salientando que esta obra traz em si a noção da fragmentação da identidade do autor a partir do objeto literário. Nesse conto, Borges coloca em cena o eu subjetivo - enquanto indivíduo real -, e a experiência do eu construída em torno da figura do autor, como exemplificada na seguinte passagem:

Ao outro, a Borges, é quem sucedem as coisas. Eu caminho por Buenos Aires e me demoro, talvez já mecanicamente, para olhar o arco de um vestíbulo e o portão gradeado; de Borges tenho notícias pelo correio e vejo seu nome em uma lista tríplice de professores ou em um dicionário biográfico. Agradam-me os relógios de areia, os mapas, a tipografia do século XVIII, as etimologias, o gosto do café e a prosa de Steverson; o outro compartilha essas preferências, mas de um modo vaidoso que as transforma em atributos de um ator (BORGES, 1999, p. 202).

O eu que caminha por Buenos Aires é aquele que gosta dos relógios de areia e sabe apreciar o gosto do café; já o outro eu é Borges, de quem se tem notícias pelo correio e consegue ver o nome estampado em listas de assuntos diversos. É evidente, portanto, que a essa distância, entre a experiência do eu de autor e a figura do autor construída, lança luz sobre a questão da alteridade e sua problemática, como verificamos em Fernando Pessoa

\footnotetext{
${ }^{32}$ Essa corrente da crítica literária teve como principais precursores T.S. Eliot e William Empson, mas foi somente em 1941, que John Crowe Ransom (1888-1974) publicou o livro New criticism, dando nome ao movimento.

${ }^{33}$ Além de seu contexto moderno, no qual foi originado, o New Criticism também ocupa lugar central nos estudos da produção e recepção de escritos literários da Antiguidade Clássica.

${ }^{34}$ Em latim "ficção" é fictio, que corresponde ao verbo fingere, cujo significado é: fingir, modelar, inventar. Assim, a palavra "fícção" em Literatura remete ao signo da representação. Logo, o representado, que pode ser o escrito, a encenação teatral, entre outros, não corresponde ao real.
} 
(1976) ao fazer a analogia entre o jogo e a vida por meio do famoso verso "o poeta é um fingidor" (p. 201). Objetivamente, na proposição "autor" como "ator", conforme a colocação de Chartier (2012), Borges indaga sobre a figura do autor como inventor, colocando em evidência não só a questão da identidade múltipla entre autor e narrador, como também confere uma dúvida sobre a "atribuição da criação estética a uma subjetividade autoral" (p. 40), como é implícito na seguinte passagem: "Não me custa nada confessar que ele [Borges] alcançou certas páginas válidas, mas estas páginas não podem salvar-me, talvez porque o bom já não seja de ninguém, nem mesmo do outro, mas da linguagem ou da tradição" (BORGES, 1999, p. 54). Dentro dessa lógica, em que “a ficção mostra a relação recíproca que liga o 'eu' a Borges" (CHARTIER, 2012, p. 40), Chartier considera, por fim, que “o ‘autor' não é apenas uma função que desloca e transforma a personalidade de um indivíduo que escreve; é também uma ficção que proporciona realidade a uma ausência" (2012, p. 40). Assim, no instante em que o autor cria uma personagem, fruto de sua imaginação, ele dá vida a essa personagem.

Desse cenário, no qual o objeto literário é resultado da exclusão do autor, como estabelecido por Roland Barthes em 1968, no clássico ensaio “A morte do autor" (2004), Barthes afirma que o autor se revela como uma personagem moderna, sendo, pois, fruto da cultura e do social de cada sociedade em relação à escrita, a qual é destituída de voz e de origem: "a escritura é esse neutro, esse composto, esse oblíquo pelo qual foge o nosso sujeito, o branco-e-preto em que vem se perder toda identidade, a começar pela do corpo que escreve" (BARTHES, 2004, p. 57). Assim, uma vez que a escrita entra em cena, processa-se a morte do autor, o que significa, afinal, que para o semiólogo francês, a linguagem ganha vida porque a própria vida já é o texto. Há, nesse sentido, uma inversão dos papéis em que o autor é a personagem e o texto é quem cria não somente a escritura, mas também a cultura e o social. Mediante a essas considerações, a argumentação de Barthes se faz a partir da definição de que o eu que escreve é, por definição, um sujeito vazio que só existe enquanto enuncia o discurso, ao passo que o texto se constrói e se reinventa a partir de outros textos: "o texto é um tecido de citações, oriundas dos mil focos da cultura" (BARTHES, 2004, p. 62).

Por essa perspectiva, Vasconcellos (2016) adverte, no entanto, que ao fazer a distinção entre a voz autoral e a voz construída no texto, em qualquer poesia escrita em primeira pessoa, devemos ter cautela ao julgar esses discursos como sendo puramente ficcionais. Um exemplo que o autor nos mostra, e que considera ser habitual nos estudos clássicos, é a leitura 
biografista de Catulo ${ }^{35}$ - nos poemas de Lésbia -, na qual o eu expresso na poesia subjetiva do poeta está associado à vivência do autor, e este, recebe, por consequência, a imagem estereotipada do poeta romântico. Nesse caso, Vasconcellos esclarece que esse tipo de leitura é geralmente feito a partir da extração de elementos mínimos do texto, portanto tomados como realidade factual ${ }^{36}$. Em verdade, não se deve ignorar a construção retórica da voz presente no texto, como excluir elementos autobiográficos.

Essa discussão se torna evidente ao nos depararmos com a escrita de Maura Lopes Cançado, em Hospício é Deus. Corroborando o pensamento de Antoine Compagnon (2012, p. 80 ), a própria obra da autora evidenciaria a intenção do autor por ser uma mistura de gêneros, na qual identificamos a autobiografia, memórias e diário. Consequentemente, a obra de Maura é, por assim dizer, relativizada, uma vez que não é possível ignorar o contexto do manicômio, no qual a escrita foi elaborada, assim como as crenças da autora, os seus valores e os seus pensamentos. A bem da verdade, os fatos biográficos podem exercer certa influência na interpretação da obra quando estamos diante das escritas de si. No entanto, a escrita da autora, conforme veremos adiante, encerra um tipo particular de narrativa ficcional, já que ao escrever ela está não só inserindo elementos de sua vivência, como reconstruindo a experiência do passado e, ao fazer isto, a experiência da escrita torna-se também ficcional ${ }^{37}$, caracterizando, por sua vez, o diário como gênero literário. Partindo dessas observações, há que se considerar que as evidências externas ao texto não constituem, desse modo, uma leitura acabada e completa.

Diante dessas duas visões, a experiência narrativa da autora leva-nos a refletir sobre a questão da sinceridade ${ }^{38}$ na sua escrita autobiográfica, uma vez que seu relato pressupõe um contrato com a verdade no que respeita a sua condição primeira, qual seja, a de testemunha crítica - a qual lhe permite descrever e denunciar as condições no hospício. Dessa condição, a pergunta que merece reflexão é: até que ponto podemos confiar nesse narrador?

\footnotetext{
${ }^{35}$ Caio Valério Catulo (século I a.C) foi um poeta romano durante o final do período republicano. Sua fama se deve ao fato de ter adotado em muitos de seus poemas "[...] um estilo de humor cáustico e obsceno" (MIOTTI, 2010, p. 17).

${ }^{36}$ Por essa razão, o autor decide pela preservação das duas categorias, quais sejam, a visão biografista e o conceito de persona, já que observa certo incômodo em tratar ambos os conceitos de maneira simplista ao escolher se apropriar somente de um viés.

${ }^{37}$ Vale a pena chamar a atenção para o fato de que a memória engana e trai a linguagem da própria autora, ao passo que a ficção surge na vontade de uma verdade sincera. Na próxima seção deste capítulo, "Os limites entre arte e vida: autobiografia, memória e diário", buscaremos desenvolver a questão da memória mais detidamente.

${ }^{38}$ É importante frisar que, para Maura, ela estaria sendo sincera, porque a memória recordada só pode ser lida como falsa por uma outra pessoa, e não pela a que se lembra.
} 
Todavia, nosso foco, nesta pesquisa, não é discorrer sobre o modo de recepção na literatura íntima, mas buscar, através do leitor, um ponto de análise entre os limites ficcionais e não ficcionais no relato autobiográfico de Maura Lopes Cançado, pois é a partir do leitor que nos debruçamos sobre a pergunta exposta acima.

\subsection{OS LIMITES ENTRE ARTE E VIDA: AUTOBIOGRAFIA, MEMÓRIA E DIÁRIO}

Estou no Hospício. O desconhecimento me cerca por todos os lados. Percebo uma barreira em minha frente que não me deixa ir além de mim mesma. Há nisto tudo um grande erro (CANÇADO, 2016a, p. 31).

Reacendendo uma questão há muito conhecida nos estudos da escrita do eu, os limites entre arte e vida perpassam os antigos até os escritos contemporâneo. E desse contexto, uma pergunta que se faz notar é: como saber que esse "eu" que escreve é quem diz "eu"? Embora não se possa afirmar, com exatidão, que o leitor da Antiguidade levantasse essa questão que hoje, modernamente, tornou-se objeto de investigação entre os críticos, sobretudo nas narrativas de testemunho, Vasconcellos (2016) apresenta análises de estudiosos acerca do poema $16^{39}$ de Catulo (século I a.C) - famoso nos estudos clássicos -, que remete à questão entre o plano da ficção poética com o plano da realidade, a fim de comprovar que entre os antigos a confusão era evidente entre o ethos construído na poesia e o ethos do escritor empírico, revelando que havia ambiguidade entre essas duas instâncias.

Nesse poema, interessa-nos, sobretudo a persona satírica a quem Catulo nomina com seu próprio nome, compondo versos com uma grande carga de ofensas destinadas à Fúrio e Aurélio, duas personagens que se pautaram nas leituras dos poemas de Catulo sob o viés biográfico, questionando a virilidade do poeta. E Catulo, ao tratar da temática do cotidiano em seus poemas, representando a persona do eu, transformava essa realidade em composição artística. Dessa forma, a experiência poética de Catulo pode ser interpretada como um jogo literário, o qual comumente aparece em muitos de seus poemas, oferecendo, desse modo, um olhar acerca da distinção entre os dois ethos enunciativos. A esse respeito, Vasconcellos (2016, p. 71) considera que:

\footnotetext{
${ }^{39}$ Entre os mais famosos poemas de Catulo, o poema 16 mostra uma composição poética dotada de virulência e obscenidade. Nesse poema, Catulo condena Fúrio e Aurélio por uma identificação do "eu" da poesia subjetiva com o biografismo de seu autor. Sendo assim, "Fúrio e Aurélio são, em suma, representantes típicos de certa leitura que qualquer leitor (uos qui legistis) poderia fazer - e contra essa postura 'biografista' o poema adverte” (VASCONCELLOS, 2016, p. 62).
} 
Catulo representa-se sob a persona de um apaixonado, escrevendo versos "delicados", segundo se convencionara, como se a brincadeira poética do dia anterior continuasse. A experiência poética é conotada como uma relação amorosa; mas a relação amorosa também pode ser interpretada como um jogo literário.

Como verificamos no excerto acima, Vasconcellos $(2016$, p. 31) retrata que na poesia da Antiguidade havia, em algumas comunidades, o contexto da performance, segundo a qual a poesia, recitada na sua modalidade oral, era um meio pela qual o autor assumia a voz da personagem do poema. No entanto, quando a cultura da performance não foi levada em consideração - seja porque houve a perda da memória desse tipo de representação; seja porque a cultura letrada não implicou tal dramatização - houve, por conseguinte, a associação da experiência do autor empírico com a persona poética. Porém, ainda que muitos estudos se debrucem sobre a questão da persona na Antiguidade, o pesquisador considera que, em tempos mais recentes, têm sido cada vez mais comum 'tratar da identificação do 'eu' da poesia amorosa romana com o autor de carne e osso como uma espécie de falácia (pós)romântica" (VANCONCELLOS, 2016, p. 53), salientando que, quando se está diante da poesia subjetiva, via de regra, o modo de leitura é feito sob a negação dessa influência de concepção romântica, a qual estabelece que a emoção expressa na poesia é também a própria experiência amorosa de seu autor. Eis porque, nessa acepção romântica, tantos leitores e críticos foram, e ainda são, segundo o autor, influenciados pela leitura, na qual a escrita em primeira pessoa faz reportar à biografia de seu autor empírico. Desse contexto, Vasconcellos observa que:

[...] críticos e leitores em geral se deixariam desviar, lendo tudo o que expressa ego da poesia amorosa como relato autobiográfico do autor empírico, não levando em consideração quanto de convenção genérica permeia a produção antiga, o quanto de fictum, em suma, tem essa poesia, que não seria interpretada em seu meio de produção como nós durante bom tempo a interpretamos (2016, p. 53-54).

Cabe assinalar, por ora, a escrita contemporânea subjetiva, mais precisamente, a escrita autobiográfica. O nome que legitima os estudos de tal gênero é Philippe Lejeune. Não é possível referir-nos à literatura autobiográfica sem falar desse autor responsável por fazernos refletir sobre uma das práticas de expressão do eu, que, à maneira do diário, é também "laboratório de introspecção" (2008, p. 263) e produção artística. Em sua obra, O pacto autobiográfico (2008), a definição de autobiografia se constrói na retrospectiva dos eventos 
narrados "que uma pessoa real faz de sua própria existência, quando focaliza sua história individual, em particular a história de sua personalidade" (LEJEUNE, 2008, p. 14). Nesse tipo de narrativa, a identidade deve se apoiar na tríade em que autor, narrador e personagem seriam uma só. Assim, para Lejeune, a existência dessa relação de identidade se faz possível quando há uma identificação entre o nome do autor - escrito na capa do livro -, narrador e personagem principal, os quais corresponderiam, então, a uma única identidade.

Em face dessa definição, o teórico francês estabelece a concepção de pacto autobiográfico, para o qual a leitura é mediada por uma forma de contrato entre autor e leitor. Nessa lógica, quem escreve tem um compromisso com a verdade - aliás, a questão da verdade é discutível - e quem lê, buscaria elementos dessa "suposta verdade" [grifo meu] na escrita autobiográfica, ao contrário do romance, no qual existe outro tipo de pacto, o pacto romanesco (LEJEUNE, 2008). Ou seja, para Lejeune, é o leitor quem irá atribuir significados à intenção do autor, desde que ele aceite fazer parte do jogo que o autor propõe. Logicamente, esse contrato não é explicitado ao leitor, que só consegue construir a imagem do real por meio de elementos paratextuais implícitos que condicionam a leitura, a saber: assinatura, subtítulo, publicidade etc..

Nesse sentido, considerando que "o tema profundo da autobiografia é o nome próprio" conforme formulado por Lejeune (2008, p. 33) - em que o nome próprio seria o ponto essencial para a existência de uma identidade do autor com a personagem principal da narrativa -, Serge Doubrovsky, criador do termo "autoficção", contrapõe a premissa de identidade de Lejeune acerca do gênero autobiográfico, o qual é definido, como vimos, a partir desses três termos: autor, narrador e personagem. Não encontrando nenhum romance ficcional em que o escritor empírico seja também narrador e personagem, Doubrovsky compõe Fils, cuja obra, assinada em seu nome, é uma narrativa na qual elementos do real e do ficcional se mesclam, criando desse modo o neologismo, autoficção, cujo conceito é representado como a metáfora do espelho. Disso decorre que, a identidade da autoficção se constrói na relação em que autor, narrador e personagem seriam os mesmos, mas, segundo o autor, "mesmo querendo dizer a verdade, se escreve falso. Se lê falso. Loucura. Uma vida real passada se apresenta como uma vida fictícia futura. Contar sua vida é sempre o mundo às avessas" (DOUBROVSKY, 1989, p. 92 apud FIGUEIREDO, 2013, p. 11).

Do mesmo modo, Jean Starobinski, para quem é também referência nos estudos da autobiografia, aponta para a questão da autorreferência do escritor autobiográfico (ARFUCH, 2010 , p. 54) ressaltando que, no momento da escrita, mesmo que a intenção com a verdade 
seja um compromisso desse tipo de registro, essa intenção será falível uma vez que seria impossível reproduzir, de maneira absoluta, os acontecimentos passados.

Tal qual demonstrado, tanto Doubrovsky como Starobinski, consideram que não é possível delimitar o espaço entre a ficção e o gênero autobiográfico, porque acreditam que é errado supor que exista uma verdade literal no gênero confessional. A respeito disso, Starobinski esclarece que: "sob a forma de autobiografia ou confissão, e apesar do desejo de sinceridade, o 'conteúdo' da narração pode escapar, se perder na ficção, sem que nada seja capaz de deter essa transição de um plano para outro" (STAROBINSKI apud ARFUCH, 2010, p. 54).

Evidentemente, não nos restam dúvidas de que para esses autores não é possível recompor toda uma vida no registro escrito mesmo que nos esforcemos para recuperar elementos de nossa vida com fatos, fotografias, descrições detalhadas de ambientes e pessoas e, ainda, recorrermos às testemunhas de nossas experiências. As lembranças serão, de certo modo, sempre revestidas de recomposições de fatos e episódios, pois voltar ao passado implica reviver uma experiência que, consequentemente, se transforma em outra. Assim, é seguro afirmar que um outro "eu" é criado no instante em que desejamos revisitar o passado.

Em seguida a essas considerações, Philippe Artiéres (1998), ao falar das formas dos arquivos como um modo de se fazer existir - e isso inclui qualquer espécie de documentos tais como cartas, listas de tarefas, cartões postais, entre outros - considera ser a autobiografia uma forma pela qual a intenção do autor é declarada. Para Artiéres, a autobiografia é antes de qualquer coisa uma prática mais elaborada desse tipo de arquivamento, porquanto quando pensamos em escrever um relato de nossas vidas, selecionamos os acontecimentos que julgamos serem mais apropriados narrar e os ordenamos numa sequência narrativa (ARTIÉRES, 1998, p. 11). Efetivamente, o ato de narrar a si mesmo determina nossas escolhas e os sentidos que desejamos dar à nossa história e tudo aquilo que escolhemos descrever de nossas vidas, tornam-se objeto de criação.

Assim, partindo das reflexões acima, consideramos ser a autobiografia de Maura Lopes Cançado uma narrativa construída na sua forma retrospectiva, buscando recuperar elementos de sua vida e organizá-los como lhe seja mais conveniente. Nas palavras de Artiéres:

O arquivamento do eu não é uma prática neutra; é muitas vezes a única ocasião de um indivíduo se fazer ver tal como ele se vê e tal como ele desejaria ser visto. Arquivar a própria vida, é simbolicamente preparar o 
próprio processo: reunir as peças necessárias para a própria defesa, organizálas para refutar a representação que os outros têm de nós (1998, p. 31).

Dentro dessa perspectiva de ver o próprio eu à distância, Alba Olmi (2006, p. 23) explica que o narrar a si mesmo torna-se também um processo terapêutico na medida em que nos proporciona um reencontro com o passado, a fim de perscrutar os caminhos que foram traçados, tornando possível "ver nossa vida numa nova luz" (OLMI, 2006, p. 24). E ao estar diante de nossas lembranças, sobretudo quando há dor ou sentimento de culpa, escrever é um meio de remediar-se e conhecer-se; é estar na posição de observador distante de si, procurando reconciliar consigo mesmo e com o passado; é, em resumo, uma tentativa (quase) fiel de recompor um retrato de nossas memórias, estas compreendidas como reconstruções da experiência humana. Eis porque, a essa experiência narrativa, a autora enfatiza que: "escrever é um modo de ser e de estar na vida. Nossa vida sempre existe dentro de uma narrativa que dirigimos a nós mesmos ou a outros" (OLMI, 2006, p. 23-24). Assim mesmo, e, entre outros motivos, escrever é também uma forma de se reportar à memória, já que "é a única que pode religar-nos a um passado ao qual pertencemos e do qual derivam nossas atitudes, nossas crenças e descrenças, nossos mitos, nossa capacidade de recriar mundos possíveis nos quais habitamos no passado" (OLMI, 2006, p. 30).

Cabe notar, entretanto, que, se nos ativermos à análise da autobiografia e do diário íntimo veremos que não é possível traçar uma linha divisória que possa demarcar e definir precisamente esses dois gêneros, pois de acordo com Olmi (2006, p. 75) cada autor imprime uma característica à sua escritura, sendo, pois, difícil a delimitação entre essas duas fronteiras. Sendo assim, no que concerne à definição de diário, remetemo-nos à Lejeune (2008, p. 263) que afirma ser uma prática íntima e, por extensão, "um espaço de análise, de questionamento, um laboratório de introspecção"; como instrumento de ação, a escrita do diário é uma forma de manter um registro do passado recente e de pensar sobre o futuro na medida em que escrever "força a formular os desafios e os argumentos, deixando vestígios que poderão ser repensados" (LEJEUNE, 2008, p. 263). De acordo com o crítico francês, isso foi verificado na argumentação dos primeiros cristãos do passado, quando incentivavam a prática do exame de consciência. É possível identificar aqui, portanto, que através das opiniões e vivências no diário, essa prática funciona como possibilidade de compreender a si mesmo frente ao tratamento da escrita e, em diversas instâncias, é também uma ferramenta de ação e resistência, como foi o caso de Anne Frank ao dedicar à escrita o meio de conservar a esperança (LEJEUNE, 2008, p. 263). Alba Olmi acrescenta ainda que: 
[...] o diário íntimo se caracteriza por alguns outros aspectos particulares: é geralmente alusivo, repetitivo, muitas vezes desestruturado, por isso, fragmentário por vezes necessitando de uma elaboração secundária quando destinado à publicação. Nasce, sobretudo, como resposta a motivações frequentemente complexas e com funções particulares e variadas (2006, p. 76).

Dentro dessa mesma citação, emerge um segundo ponto que nos é oportuno discorrer. Sobre o diário, Lejeune sustenta que, sem data, não passa de uma simples caderneta (2008, p. 260) e sua escrita não está sujeita à modificação. Quando isto acontece, o diário ganha contornos literários perdendo, assim, o valor autêntico da escrita de fórum íntimo, transformando-se, desse modo, em gênero autobiográfico. Diante disso, o autor questiona: “Quando se lê 'o mesmo texto' impresso em um livro, será de fato o mesmo? Assim como as obras de arte, o diário só existe em um único exemplar” (LEJEUNE, 2008, p. 260).

Embora desejemos, de fato, contar a história de nossas vidas seja na escrita do diário ou na escrita autobiográfica, a narrativa, enquanto processo temporal, transforma e impõe a sua matéria, deslocando o texto da vida para o texto ficcional. Nessa acepção, Eneida Maria de Souza (2004, p. 59) analisa, de forma clara e precisa, a dimensão do "saber narrativo da literatura como força capaz de criar ficções e de transformar a realidade no duplo da ficção", o que nos leva a crer que em se tratando da escrita do gênero confessional, esse saber narrativo confere à especificidade do gênero o estatuto de ato literário. Sobre esse aspecto da narrativa a autora explica que:

O entrecruzamento de momentos textuais com os vividos permite ampliar a noção de texto, que não mais se circunscreve à palavra escrita, mas alcança a dimensão de outros acontecimentos, interpretados como parte do universo simbólico (SOUZA, 2004, p. 59).

Por essa razão, quando pensamos conhecer uma verdade nas escritas do eu, provavelmente nos referimos ao fenômeno da verossimilhança, razão pela qual nem tudo que está nas entrelinhas do mundo factual é pertencente à esfera do real. A esse respeito, da questão da ars/vita na escrita de si cabe retomar as palavras de Vasconcellos (2016), nos reportando ao contexto da poesia romana de cunho subjetiva a fim de esclarecermos quanto aos limites entre as instâncias do real e do ficcional. O autor, assim enfatiza que não é possível traçar uma linha divisória nesse universo da enunciação poética com o intuito de delimitar o que é ou não fícção, mas, em certa medida, refletir por meio do contexto, da 
tradição e do social, os efeitos textuais, os quais, por vezes, resultarão da construção retórica na obra literária. Para Vasconcellos:

Há momentos na literatura ou no percurso de determinado poeta em que se busca um efeito maior de real, de confissão, de ausência de artifício, mas esses efeitos resultarão da construção retórica do texto, condicionamento inescapável. Todo texto cria um ethos para seu enunciador; assim, a impressão de sinceridade sempre será um efeito textual (2016, p. 38).

Dessas considerações, a obra Hospício é Deus não encerra em si um diário nos moldes de Lejeune (2008), porque Maura Lopes Cançado, como já acenamos, mistura gêneros como memórias, diário e autobiografia. Sua narrativa, no que concerne à estrutura do texto, à disposição e organização, está dividida em duas partes (SCARAMELLA, 2010, p. 153): a primeira é um relato autobiográfico, em que memórias da infância e da adolescência são recuperadas; a segunda é a escrita do diário, no período de internação no Hospital psiquiátrico do Engenho de Dentro.

Se, como vimos, o relato autobiográfico implica seleção de fatos ocorridos no passado da parte de quem escreve, o diário, por sua vez, se caracteriza, a nosso ver, pela escrita de acontecimentos do cotidiano, no qual a passagem do tempo ${ }^{40}$ não se mostra muito distante entre o presente e o passado como ocorre na autobiografia. Porém, a autobiografia, para Lejeune (2008), é um gênero que implica significados outros, não se restringindo à definição primeira que havia elaborado no ensaio "O pacto autobiográfico", título homônimo do livro. Neste texto, o autor importa a definição de autobiografia de Larousse, proposta em 1886, preenchendo algumas lacunas. Em seguida, n'“O pacto autobiográfico (bis)”, Lejeune aponta falhas de definição para o gênero e também acrescenta o sentido de Vapereau, definido em 1876. Assim, esse acréscimo, segundo o autor, dá à autobiografia um sentido amplo, qual seja, a ideia de apreender-se dentro de uma totalidade. Em outras palavras, a questão central é que ao olhar para o passado, o autobiógrafo seleciona as lembranças de sua vida com base nas memórias do presente, abrindo, desse modo, espaço para a fantasia. Essa postura, segundo a definição de Vapereau, isenta o autobiógrafo de ser totalmente fiel nos relatos dos fatos.

Nesse sentido, fica bastante evidente quando contrapomos o relato autobiográfico de Maura Lopes Cançado com o seu diário. No início do seu livro, a autora, quando escreve, encontra-se no hospital. Esse é o momento presente e, nessa localização, busca reconstruir seu

\footnotetext{
${ }^{40}$ A respeito dessa diferença, sutil, porém, notável, entre autobiografia e diário, percebemos uma diferença no que respeita ao cronotopos. Por definição deste termo, em literatura, Mikhail Bakhtin (1998, p. 211) assim assinala: "à interligação fundamental das relações temporais e espaciais, artisticamente assimiladas em literatura, chamaremos cronotopo (que significa 'tempo-espaço')”.
} 
passado com o intuito de compor um quadro de sua vida, e é este ponto sobre o qual se constrói a obra, já que é o presente e o local de sua enunciação que definem o que será rememorado do passado e como essa lembrança será tratada no presente por parte de quem lembra. Isso porque, a composição do relato autobiográfico da autora constitui-se na reorganização de suas memórias e na seleção de elementos de sua vida que lhes parecem mais apropriados narrar naquele momento e local. E ao fazer isso, a autora concede a seus escritos contornos ficcionais, pois todo ato de narrar implica reinventar uma nova história, já que é impossível recompor um retrato factual de nossas lembranças, conforme lemos no seguinte fragmento:

\begin{abstract}
Nasci numa bela fazenda do interior de Minas, onde meu pai era respeitado e temido como o homem mais rico e valente da região. Fui uma criança bonita, todos dizem, e sei pelos retratos. [...] As pessoas, mesmo as desconhecidas, jamais deixavam de me prestar atenção, ainda quando papai se esquecia de me mostrar, glorioso, como era seu costume. Eu era morna, doce e presente - o que se toma no colo deixando o coração macio e feliz. Sobretudo em mim havia a surpresa: esperavam apenas uma menina, e subitamente me mostrava mais. Creio que em nada desapontei. Ao contrário, como criança fui excessiva (CANÇADO, 2016a, p. 8-9).
\end{abstract}

Vejamos que, no relato, o narrador se revela como sendo também um manipulador, esforçando-se para reconstituir uma narrativa (ARTIÉRES, 1998), uma vez que dá ênfase para aquilo que lhe é mais caro e, dessa postura, esteja seu autor consciente disso ou não, a narrativa é vista em constante suspeita. Por isso mesmo, a memória é também um incentivador do fazer literário.

Entretanto, se na autobiografia, como vimos, encontramos uma organização interna da narrativa, por seu turno, o que caracteriza o diário é a sua duração - não obrigatoriamente regular - e uma série de vestígios. Sua forma é livre e seu conteúdo compreende qualquer manifestação da expressão humana. Além disso, o diário "pressupõe a intenção de balizar o tempo através de uma sequência de referências" (LEJEUNE, 2008, p. 260) tais como flores, objetos e sinais que ilustram a vida cotidiana, constituindo, em princípio, uma espécie de guardião das lembranças, em que escrever é um processo que permite recuperar e organizar as memórias, "dar-lhe uma "identidade narrativa"” (LEJEUNE, 2008, p. 262). Seguindo tal linha de análise, a escrita do diário se configura, por assim dizer, no espaço onde o sujeito pode discursar à vontade sobre aquilo que o incomoda ou aflige, colocando suas questões em um espaço neutro e particular. É, nas palavras de Lejeune (2008, p. 262), um meio de sobrevivência porque "será ao mesmo tempo arquivo e ação, 'disco rígido' e memória viva"; 
é também um desabafo, pois é um caminho onde é possível discursar e manter um discurso apenas para si, gerando bem-estar e equilíbrio individual.

Sobre o processo da memória e a forma como o sujeito se relaciona com o seu passado, elegemos a concepção de memória que leva em conta as relações do indivíduo com o meio. Para tanto, nos apoiamos nos estudos de Maurice Halbwachs (2003), quando afirma que cada memória individual é um ponto de vista sobre a memória coletiva. O autor assim considera que existe uma relação entre essas duas memórias e, em função dessa relação, defende a ideia de que nossas lembranças se constituem como coletivas mesmo que nós estivermos sós em qualquer evento e ainda esclarece que isso ocorre porque, na verdade, nunca estamos totalmente sozinhos. Não há, portanto, necessidade de outros, distintos de nós, porque sempre estaremos acompanhados por certo número de pessoas que não se confundem. Assim, os testemunhos, no rigoroso sentido da palavra, não são necessários para corroborar ou recordar uma lembrança. Em contrapartida, ao indivíduo será negada a recordação de suas lembranças se, em um grupo, as lembranças não se identificarem. Por isso, de acordo com o autor:

Para que a nossa memória se aproveite da memória dos outros, não basta que estes nos apresentem seus testemunhos: também é preciso que ela não tenha deixado de concordar com as memórias deles e que existam muitos pontos de contato entre uma e outras para que a lembrança que nos fazem recordar venha a ser reconstruída sobre uma base comum (HALBWACHS, 2003, p. 39).

Eis porque, para Halbwachs (2003), a memória coletiva é formada a partir da ordenação das memórias de vários grupos, dos quais o sujeito participa, exercendo e sofrendo influência. Desse modo, o autor relaciona as lembranças dos indivíduos como uma construção social e coletiva.

Nessa linha de pensamento, a obra Hospicio é Deus é representada pela memória coletiva e individual: coletiva porque no livro, construído como um diário, Maura Lopes Cançado, além de ser testemunha de uma minoria excluída, é a porta-voz das internas que compartilham das experiências do espaço que as encarceram, relatando suas aflições e angústias. Somado a isso, a autora descreve também as relações com médicos, enfermeiras e funcionários, bem como os tratamentos e os maus-tratos, assinalando-se, dessa forma, a literatura de testemunho como objeto de interesse por parte do historiador; a obra reflete em memória individual, em razão da loucura ali expressa, a qual desafia a compreensão da autora e sua visão romântica do hospício como um lugar fora do mundo: “22-11-1959 [...] Ninguém 
entendeu o motivo desta internação, a não ser eu mesma: necessitava desesperadamente de amor e proteção. O sanatório parecia-me romântico e belo. Havia certo mistério que me atraía" (CANÇADO, 2016a, p. 67).

Essas observações nos permitem afirmar que é preciso que haja um testemunho, que no caso de Maura é revelado pelas impressões de vida em um momento de clausura, para que um fato se perpetue e se torne memória para um grupo que, ao longo da história, sempre esteve associado ao lugar da exclusão. Desse olhar, as experiências das pessoas que historicamente compuseram o quadro de pacientes em manicômios e instituições psiquiátricas merecem, portanto, ser resgatadas. É evidente que a esse testemunho, segundo Halbwachs (2003, p. 29), recorremos "para reforçar ou enfraquecer e também para completar o que sabemos de um evento sobre o qual já temos alguma informação". O autor considera que as memórias são construções dos grupos sociais, são elas que determinam o que é memorável e os lugares onde essa memória será preservada. Em se tratando de nossa autora-narradora, sua obra é constituída em memória e documento-arquivo de uma realidade que foi palco de grandes questões acerca da psiquiatria no Brasil, antes do movimento antipsiquiátrico ${ }^{41}$ que se propagou nas décadas de setenta e oitenta do século XX.

Diante desse quadro, a concepção de memória em Maura Lopes Cançado, caracterizada aqui, em princípio, pela individual, implica digressão, já que é contrária à memória coletiva da sociedade a qual faz parte. Isto é, a experiência da autora, mesmo aparentemente particular - representada pelo viés da loucura - é uma experiência-memória que remete a um grupo, qual seja, a dos excluídos, sobretudo no que se refere à imagem da mulher na loucura.

Isso se registra quando levamos em consideração os limites do espaço privado à mulher. Em seus estudos, Simone de Beauvoir (2016), ao demonstrar que a presença da figura feminina sempre esteve associada à cultura patriarcal, nos mostra que, até o início do século $\mathrm{XX}$ era reservado às mulheres o destino de tornarem-se esposas e mães, e qualquer mudança que fugisse a esse padrão as colocava sob o julgamento de uma sociedade que lhes imputava maiores dificuldades. É o que também nos aponta Elaine Showalter (1987), nos estudos que fez sobre a sociedade de meados do século XIX e início do século XX, ao tratar da temática

\footnotetext{
${ }^{41}$ A Luta Antimanicomial ou a Reforma Psiquiátrica, realizada de 1970 a 1980 no Brasil, foi um importante movimento de contestação às práticas psiquiátricas tradicionais de assistência aos portadores de transtornos mentais. Entre outros pontos, definiram-se ações a serem tomadas contra os tratamentos violentos dispensados aos pacientes - que incluíam eletrochoques, lobotomia e quartoforte, por exemplo -, ferindo-lhes a dignidade. Assim, o movimento da reforma teve, como ponto essencial, a busca por tratamentos ancorados nos direitos humanos.
} 
da loucura feminina: se a mulher não cumprisse o papel que a ela fora destinado, não raro, era-lhe atribuída a condição patológica de insana. Ocorre que nesses contextos a loucura da mulher é julgada segundo seus padrões comportamentais não adequados às concepções dominantes da época, pois tanto a questão da maternidade fora do casamento quanto a da mulher divorciada são motivos pelos quais a mulher é discriminada e vista como personificação do perigo. Sobre as injunções sociais destinadas à mulher, vejamos o relato de Maura:

\begin{abstract}
22-11-1959 [...] A perspectiva de voltar a ser "menina de colégio interno"42 entusiasmou-me, armei-me das melhores intenções, senti que de novo me integraria em meu próprio meio, longe do estigma "casada e separada do marido". Em Belo Horizonte, com todo o meu enxoval do colégio pronto e tudo me parecendo normalizado, quando fui me internar, a diretora do colégio Isabela Hendrix, sem nenhuma explicação lógica, se recusou a receber-me. Antes, apresentou motivos vagos, dizendo que uma antiga aluna resolvera voltar e a vaga era dela. Como? - me perguntava - tudo fora combinado, mesmo meu enxoval (tão caro), comprado com tamanho cuidado! Anteriormente tudo fora dito a meu respeito: eu fora casada etc. A pessoa a quem mamãe pedira para acompanhar-me, um amigo da família, expusera todos os detalhes. [...] A injustiça pesou-me, sofri desgraçadamente, não me foi possível compreender minha posição na sociedade (CANÇADO, 2016a, p. 65).
\end{abstract}

Em suma, o conceito de loucura, de acordo com Ruth Brandão (1993, p. 183), "estaria submetido à razão masculina autoritária e opressora, que reduziria o comportamento feminino à sua adequação, ou não, ao discurso do homem sobre a mulher"43, ou seja, a mulher que assumisse uma postura independente - ser sujeito de sua própria existência - romperia com essa sociedade, a qual estabeleceu os padrões ideais de comportamento.

Passemos, então, à consideração de Halbwachs (2003, p. 30), quando assinala que o indivíduo carrega em si a lembrança, mas sempre interagindo na sociedade, já que "nossas lembranças permanecem coletivas e nos são lembradas por outros, ainda que se trate de eventos que somente nós estivemos envolvidos e objetos que somente nós vimos". É evidente, portanto, que enquanto a condição da mulher for associada à loucura no consciente coletivo de um grupo, retirando-lhe a subjetividade, ela é quem irá determinar a memória desse lugar.

\footnotetext{
${ }^{42}$ No hospício, há o retorno à infância idealizada. Também é digna de nota a analogia entre o hospício e o colégio interno. Ambas as instituições submetem aos indivíduos o mesmo modelo de comportamento - é o que Foucault (1999 [1987]) denomina como "disciplina".

${ }^{43} \mathrm{O}$ comportamento feminino nesse caso, é uma questão de disciplina falocêntrica do corpo e da alma à um determinado discurso.
} 
Sob a perspectiva da memória individual, é bom ressalvar que, ainda que o retorno do passado seja operado sob o estímulo de exigências diferentes e seguindo finalidades específicas, o seu retorno não é fácil, ainda que a origem da rememoração esteja no indivíduo. Voltar ao passado não é o único meio que organiza a experiência do subjetivo, da mesma forma que uma lembrança, como resgate das experiências individuais, não é acessada de forma plena, já que é marcada também por outras lembranças e pelo fluxo da rememoração. Halbwachs observa que:

[...] a lembrança é em larga medida uma reconstrução do passado com a ajuda de dados emprestados do presente, e além disso, preparada por outras reconstruções feitas em épocas anteriores e de onde a imagem de outrora manifestou-se já bem alterada (1990, p. 71).

Assim, lido sob a perspectiva da memória coletiva de Halbwachs, Hospício é Deus apresenta personagens que ocupam, por meio da narrativa, um lugar significativo na revisão da história, pois são personagens resgatadas do convívio do hospício, de maneira que nos permitem compreender como funciona a consciência de um indivíduo e, a partir desse indivíduo, identificar os papéis e os comportamentos da sociedade brasileira da metade do século XX. De acordo com as observações de Márcia Moreira Custódio (2017, p. 27), Maura Lopes Cançado mostra, "a partir do seu próprio testemunho, o impacto da violência, o processo de organização e funcionamento manicomial, legitimados pelo Estado, que corroborou a violação dos direitos humanos dos pacientes dos hospícios." Por isso, uma vez mais, recorremos à Halbwachs (2003, p. 61) quando sublinha que "as leis naturais não estão nas coisas, mas no pensamento coletivo". Logo, as lembranças de acontecimentos distantes referentes ao tempo, ao lugar, às pessoas, acontecem na relação entre a memória individual e memória coletiva, o que explica que "a representação das coisas evocada pela memória individual não é mais do que uma forma de tomarmos consciência da representação coletiva relacionada às mesmas coisas" (HALBWACHS, 2003, p. 61).

De fato, por ser o diário uma das manifestações da expressão humana, uma espécie de amigo confidente daquele que confia a palavra à escrita, a narrativa de Maura Lopes Cançado, na acepção de diário de Lejeune (2008), serve-se de instrumento para a percepção de si mesma. Em razão disso, a autora tem consciência de si e faz desse espaço um lugar político no qual é possível traçar sua própria identidade, pois de acordo com Celia Musilli (2014, p. 47): "a escrita lhe devolve um lugar social e intelectual. [...] O diário, à primeira vista, é o tijolo de construção intelectual que alicerça a manutenção da sua identidade". Assim, mesmo 
que existam correntes da crítica literária que julgam ser a obra dissociada da vida de seu autor, observamos, muitas vezes, que a literatura pode ser fruto da vivência do escritor, mesmo reconhecendo que não é necessário o conhecimento desta vida para o entendimento e a apreciação da arte (NEVES, 2018, p. 53).

\subsection{A LOUCURA COMO FORMA DE NARRAR A EXPERIÊNCIA}

Venho sozinha para o hospício; se me obrigassem, lutaria com todas as minhas forças para não vir (CANÇADO, 2016a, p. 148).

No contato com a escrita e a loucura de Maura Lopes Cançado, uma breve exposição introdutória acerca do processo de construção social da loucura, em perspectiva histórica, se faz necessária. Assim, um olhar para a escrita dessa autora no século XX requer que voltemos ao passado, a fim de compreendermos essa condição na qual a autora se encontra, para, em seguida, refletirmos sobre o lugar ocupado por ela, lugar esse que a torna testemunha de uma minoria excluída, ao situá-la dentro de um espaço que também reflete a consciência do eu: o manicômio ${ }^{44}$.

Ao longo da história, a loucura ocupou diversos lugares na sociedade e durante muito tempo não fora classificada como uma patologia, seus critérios eram meramente outros. Embora fosse vista como um estado que fugisse à normalidade do discurso legitimado, os antigos gregos viam a loucura como um fenômeno que provinha do saber, isto é, o "louco" era uma espécie de ponte ${ }^{45}$ com o divino (PESSOTTI, 1994), sendo, dessa maneira, venerado e respeitado. A Idade Média, por sua vez, o associava aos vícios e aos defeitos, e qualquer expressão da ordem da inquietude figurava numa manifestação demoníaca (PESSOTTI, 1994). Contudo, ao final desse período, a loucura passa a adquirir então novo caráter: "ela conduz todos a um estado de cegueira onde todos se perdem ${ }^{46}$, o louco, pelo contrário, lembra

\footnotetext{
${ }^{44}$ Em Vigiar e Punir (1999 [1987]), Foucault define as instituições disciplinares como um sistema de repressão, o qual é responsável por controlar e reforçar atitudes de vigilância e adestramento dos corpos e das mentes dos indivíduos. Exemplos dessas fórmulas gerais de ordenamento de discursos são as escolas, as igrejas, as prisões e os hospícios. Segundo Foucault (1999 [1987], p. 163): "é dócil um corpo que pode ser submetido, que pode ser utilizado, que pode ser transformado e aperfeiçoado". Aqui, disciplina, em seu conceito moderno, é entendida como um instrumento de dominação e poder, conceito esse destinado a moldar os comportamentos considerados divergentes segundo a lógica dominante.

${ }^{45} \mathrm{Na}$ acepção dos gregos, o Louco fala a verdade que escapa dos discursos oficiais.

${ }^{46}$ Ressalte-se, aqui, as representações conhecidas ao final da Idade Média, como nos contos e sátiras, em que a loucura desempenhava o caminho da perdição, da falta de juízo. Posteriormente, ainda nesse
} 
a cada um sua verdade" (FOUCAULT, 2009, p. 14). Já no início do Renascimento, a loucura exibe nova feição: enquanto que na Idade Média, como vimos, ela assumia o caráter de crítica social, agora ela passa a ser a detentora da verdade, cujo alcance não está entre aqueles ditos normais, pois, nesse caso, é percebida como um saber proibido. Nas palavras de Michel Foucault:

Este saber, tão inacessível e temível, o louco o detém em sua parvoíce inocente. Enquanto o homem racional e sábio só percebe desse saber algumas figuras fragmentárias - e por isso mesmo mais inquietantes -, o louco o carrega inteiro em uma esfera intacta: essa bola de cristal, que para todos está vazia, a seus olhos está cheia de um saber invisível (2009, p. 21).

Também o século XVII nos traz uma nova faceta da loucura no plano social: o que antes era fruto das forças naturais ou divinas passa a ser objeto da não-razão e, desse modo, aquele que não se enquadrasse na concepção cartesiana do "penso, logo existo", estaria condenado às casas de internação. Foucault (2009), procurando delimitar esse novo espaço concebido nesse século, assim se expressa: “o sentido do internamento se esgota numa obscura finalidade social que permite ao grupo eliminar os elementos que lhe são heterogêneos ou nocivos" (p. 79). O autor comprova então que nessas casas se agrupavam não somente as "cabeças alienadas", como também toda ordem de pessoas que representassem perigo para o Estado e para a família burguesa: os pobres, os vagabundos e os presidiários. Em outras palavras, a fim de evitar o escândalo de ter um "louco" em casa, os familiares pediam a internação de seus parentes nos chamados Hospitais Gerais. Essa ideia foi melhor endossada no século XVIII com o advento do Iluminismo e, para efeito, as luzes da razão que até então iluminaram o mundo moderno, romperam o diálogo com a loucura e o saber que ela produzia. Não será por mero acaso que com a chegada do século XIX ela irá compor um novo cenário - de uma questão de ordem social para uma questão médica, a loucura receberá então novo status: o de doença.

Como pudemos observar, desde a Grécia Antiga até o século XIX, a loucura passou por uma intensa transformação e seu conceito está diretamente relacionado à construção social. Dado esse contexto histórico e, oferecendo especial atenção ao século XX, interessanos, portanto, refletir o significado de loucura na obra Hospício é Deus, em que Maura Lopes

período, "a denúncia da loucura torna-se a forma geral da crítica", incluindo outros gêneros, tais como farsas e sotias, nas quais "a personagem do Louco, do Simplório, ou do Bobo assume cada vez maior importância. Ele não é mais, marginalmente, a silhueta ridícula e familiar: toma lugar no centro do teatro, como o detentor da verdade - desempenhando aqui o papel complementar e inverso ao que assume a loucura nos contos e sátiras" (FOUCAULT, 2009, p. 14). 
Cançado busca organizar pela escrita seus pensamentos e dramas psíquicos transformando sua experiência pessoal em narrativa literária.

Sendo o sofrimento psíquico uma das causas e origens da loucura - esta representada segundo a definição da medicina no entresséculos XVII-XIX -, essa condição muitas vezes, faz suscitar ao artista pensamentos voltados às questões de ordem subjetiva e existencial, culminando, ao seu modo, na criação do objeto artístico. Para lembrar apenas de duas figuras representativas do artista-louco, fora do discurso normativado, temos Antonin Artaud e Van Gogh que se encontrando imersos nos abismos psíquicos, trouxeram-nos, respectivamente, textos e pinturas de uma lucidez desconcertante e que nos impulsionam, até hoje, às interrogações de toda ordem. Suas consciências foram duramente ignoradas e repreendidas pela sociedade da época, sendo relegados à uma condição de marginalidade. Por essa razão, esse "eu", o qual se mostra fragmentado e subjugado, é resultante não somente dos distúrbios de ordem psicopatológicas, mas, também, e, principalmente, é fruto de uma sociedade que faz calar o indivíduo, para quem se arrisca a desviar dos critérios e padrões de normalidade, os quais são estabelecidos por uma ordem social. Novamente, o sujeito-artista é convocado a mergulhar no profundo silêncio, voltando-se, portanto, para as questões de ordem interior. Desse contexto, o voltar-se para o interior é, por assim dizer, caracterizado pela linguagem da loucura, a qual, em princípio, é constituída por uma linguagem imprópria, com desvios à norma e dimensionada para os campos do delírio, do fragmentário e do fantástico. Para Foucault (2009), a representação da loucura é caracterizada sob o signo da alteridade, de modo que:

O louco é o outro em relação aos outros: o outro - no sentido da exceção entre os outros - no sentido do universal. Toda forma de interioridade é, agora, conjurada: o louco é evidente, mas seu perfil se destaca sobre o espaço exterior; e o relacionamento que o define entrega-o totalmente, através do jogo das comparações objetivas, ao olhar do sujeito razoável (p. 183).

Nesse ponto, a representação da loucura em Hospício é Deus, é baseada em uma experiência de desajuste que aspira romper as fronteiras entre literatura e vida, tornando-se, a escrita, um experimento com o corpo da própria escritora, uma vez que sua obra é vista a partir dos conflitos internos, pois nela encontramos as expressões comuns da natureza humana: a dor, o medo, a raiva, o sentimento de rejeição, o abandono e a solidão.

Separada da sociedade, a qual não mediu esforços por excluí-la de suas atividades, tal como ocorreu a Artaud e Van Gogh, a loucura em Maura Lopes Cançado é manifestada não 
como a anulação da expressão do pensamento e discurso, mas, principalmente, como elemento criador. Nesse diário, ao retornar ao passado na tentativa de compreender o presente, Maura recupera memórias da infância até momentos antes de sua entrada no hospital, quando tinha $18 \operatorname{anos}^{47}$, e, com isso, a escrita de si a leva a buscar a sua identidade que fora fragmentada em razão da sua não presença no seio da sociedade mineira de sua época, que a rejeitou por ser mãe solteira e divorciada ${ }^{48}$. Ela teve grandes perturbações ao encarar os fatos de sua realidade, os quais lhe modificavam cada vez mais o ânimo, pois não bastasse à condição feminina, sua identidade era fragilizada pela condição da loucura. $\mathrm{O}$ entendimento claro do que estava sentindo é enunciado: "26-11-1959 [...] Eu clamava contra o mundo, minha revolta era tão justa que médicos e enfermeiras fingiam não escutar-me. Como me achava lúcida: meu cérebro vertiginoso deixava-me solta no ar" (CANÇADO, 2016a, p. 78).

Assim, o encargo que a sociedade impõe à mulher das décadas de 1940 e 1950 foi um dos motivos pelos quais a autora se distanciou do convívio social, por não conseguir viver conforme os valores e a moral burguesa. Durante a permanência na Casa de Saúde Santa Maria, em Belo Horizonte, ela comenta: “22-11-1959 [...] via pessoas andando normalmente, e pensava: como podem viver livres e desprotegidas? Como se sustentam em vida? Como viver no mundo sem sofrer, se é tudo tão perigoso e inusitado?" (CANÇADO, 2016a, p. 67). E a soma de suas decepções e amarguras a levou a internar-se, por conta própria, nesse sanatório. Acerca desse assunto, Daniele Aparecida Batista (2010, p. 42) atesta que "Maura tem consciência daquilo que a impede de transpor os muros do hospício, por isso busca justificativas daquele presente no passado". E é nesse ponto que observamos que ela busca construir para si um discurso que a legitime naquela condição que a sociedade lhe vê e lhe impôs. Consequentemente, a escrita torna-se um imperativo que a insere novamente na sociedade.

É também importante lembrarmo-nos do fato de que o diário de Maura Lopes Cançado, de acordo com Maria Luisa Scaramella (2010), não se constitui como uma escrita íntima nos moldes tradicionais, por dois motivos: primeiro porque sua escrita se mostra "trabalhada, lapidada e selecionada" (p. 144) - havendo na narrativa uma sequência ordenada dos fatos; e segundo, porque Maura, no momento da escrita de seu diário, era colaboradora do

\footnotetext{
${ }^{47}$ Ver. M. L. Scaramella (2010, p. 133): "Maura relata em seu diário que estava com dezoito anos, mas de acordo com o ano, mês e dia de nascimento, se a data da internação estiver correta, estava com 20 anos".

${ }^{48}$ Por esse motivo, não pôde usufruir das mesmas condições das jovens de seu tempo, como voltar a estudar no colégio interno.
} 
Suplemento Dominical do Jornal do Brasil, onde publicava seus contos. E, estando ao lado de intelectuais que compunham o quadro do jornal, como Ferreira Gullar, Carlos Heitor Cony, Reinaldo Jardim, dentre outros, a influência literária e artística da época se fazia notar na sua escrita, conforme é demonstrado na seguinte passagem, na qual a loucura, como em toda a sua obra constitui objeto primeiro de sua narrativa:

1-2-1960 [...] A sensação que se tem é esquisitíssima. E não poderei descrever bem o quadro nem minha emoção. O cinema captaria exatamente. Algumas mulheres se conservam imóveis, absurdas, fantásticas, sentadas no banco ou no chão de cimento. Mudas, incomunicáveis, olhando nada aparente, talvez percebendo em excesso. "Quantos mundos visitei?" - já disse também isso num poema. [...] O pátio de mulheres. Qual o segredo de passar a vida, em luta ou renúncia? - renunciar a quê? Lutar por quê? Se para todas as portas estão trancadas - os muros altos definem claramente (CANÇADO, 2016a, p. 159).

Desse contexto, podemos considerar a ideia da intenção de publicação, de modo que seu diário se torna um laboratório para a sua escrita, esta se constituindo como exercício literário. A imagem de si é, então, ancorada no estigma da loucura, em que notamos que na narrativa de Maura, nos dizeres de Scaramella (2010, p. 150), "há um misto de tragicidade atrelada à elegia do hospício". Sendo assim, Daniele Batista (2010, p. 10) concebe o diário da autora "como criação literária cuja verdade, aos poucos, turva-se com os ares da mentira transformando tudo em ficção". Efetivamente, Maura revela em várias passagens seu desejo de tornar-se escritora de sucesso e, em alguns momentos, faz menção à sua produção de contos: “19-11-1959 [...] Meu conto, “O sofredor do ver”, está me custando. Falei dele a Reynaldo. Considerou o título magnífico. É o conto que mais tem exigido de mim. Consideroo muito cerebral. Talvez seja minha obra-prima" (CANÇADO, 2016a, p. 62).

Tais apontamentos corroboram, como já assinalamos, a ideia de uma possível motivação à publicação de seu "diário de internação" (SCARAMELLA, 2010), o qual relata o cotidiano de uma instituição psiquiátrica brasileira. Nesse processo, sua escrita é marcada pela denúncia quando descreve os abusos e maus tratos a que ela e outras internas foram submetidas. Assim, nesse jogo de escrever para sair da ausência de si mesma, Maura, além de trazer o leitor para o seu mundo interior, revela o contexto do drama das instituições psiquiátricas ao relatar casos de violência, como o ocorrido com uma paciente do hospital ${ }^{49}$ :

\footnotetext{
${ }^{49}$ Temos aqui uma experiência da qual o leitor interage com o texto na medida em que ele participa do jogo de reflexão e crítica mediante a uma consciência histórica - no caso do sistema antes da reforma psiquiátrica no século XX no Brasil.
} 
“30-12-1959 Durvaldina tem um olho roxo [...] abraçou-me chorando, pediu-me que a tirasse de lá. O quarto é abafadíssimo, e sujo" (CANÇADO, 2016a, p. 126).

No que consistem, precisamente, as práticas institucionais, na menção ao quarto-forte, símbolo da violência física e psicológica, é, entre outras, experiências traumáticas postas em relevo em várias passagens do diário, nos aproximando de uma realidade na qual "a loucura é exatamente aquilo que destitui os internos de seus direitos" (SCARAMELLA, 2010, p. 173). Isso seguramente confere à escrita de Maura uma "consciência crítica de oposição aos valores vigentes" (BATISTA, 2010, p. 7), consciência esta que faz de sua escrita laboratório literário, transformando as palavras em material potencialmente subversivo quando faz denúncia social e crítica àqueles que lhes imputaram a condição de louca:

30-11-1959 [...] Os médicos são de uma incoerência escandalosa; por mais que queiram negar, estão de acordo com os "castigos", aprovam-nos ou mandam até mesmo aplicá-los. É necessário levar em consideração que são estes mesmos médicos que classificam os doentes, "acusando-os" (é importante) de irresponsáveis (CANÇADO, 2016a, p. 83).

Dessas considerações, Scaramella (2010) sublinha que não é errado supor que Maura sabia da condição de seu diário ser publicado. A autora-narradora em relação ao quarto-forte, acrescenta que:

30-12-1959 [...] Dona Dalmatie disse que o professor Lopes Rodrigues, diretor geral do Serviço Nacional de Doenças Mentais, proferiu, aqui, um discurso, na porta (nas portas, porque são três) do quarto-forte, dizendo mais ou menos isto: "Este quarto é apenas simbólico, pois na moderna Psiquiatria não o usamos". - Por que então estes quartos nunca estão vagos? (CANÇADO, 2016a, p. 126-127).

Desse cenário trágico, Daniela Birman (2016) em seu artigo "Notas sobre a marginalidade: o periférico, o agregado e o louco no campo literário contemporâneo", considera que a dimensão da experiência da autora "é conduzida por uma percepção visual que elimina qualquer dimensão de banalidade dos acontecimentos" (p. 33), pois ao mostrarnos como é a condição de uma interna, descrevendo o plano de vida no hospício por meio de denúncias, Maura, ao mesmo tempo, se "desprende da realidade" (BATISTA, 2010, p. 87) e encerra no seu mundo, assinalando a loucura como uma lucidez viva: "Hospício sãos as flores frias que se colam em nossas cabeças perdidas em escadarias de mármore antigo, subitamente futuro - como o que não se pode ainda compreender" (CANÇADO, 2016a, p. 26). Nesta 
passagem, assim como em toda a sua $\mathrm{obra}^{50}$, o leitor consegue sem a descrição exata, apreender o que seria viver no hospício; o que é o hospício e o não saber sobre o hospício.

Precisamente ao inscrever suas experiências no diário, a autora dá corpo às suas memórias e, nós leitores, por consequência, preenchemos as lacunas de sua experiência: ler o diário é estar junto de Maura, porque seu corpo, como uma construção discursiva ${ }^{51}$ (FOUCAULT, 1999 [1987]), nos conecta com o seu passado e com a dura realidade de seu presente. Nas palavras de Daniele Batista (2010, p. 26) “o diário escrito na instituição psiquiátrica almeja ser uma ponte de diálogo entre o mundo 'entre as grades' e o seu exterior, entre a instituição e a sociedade". E Maura faz desse diálogo uma forma de comunicação expressiva quando descreve com esse saber do corpo; um corpo como espaço efetivo de resistência, cujo movimento toma forma e se emancipa por meio da consciência das palavras a fim de situar em nós a experiência da loucura, e convencer-nos de que por trás do seu diagnóstico existe uma consciência outra, ou seja, ela descobre no exercício da escrita uma forma de se fazer presente no mundo, como escreve em seu diário.

8-2-1960 [...] Apesar de tudo, existo com inteligência cada momento. Mas estou quase sempre entregue a perturbações psíquicas. É neste brinquedo de ser louca que se exaurem minhas energias. Se escrevesse com a sofreguidão com que tomo consciência de súbito de estar viva, jovem, bonita - feliz. E muito infeliz. Mesmo agora poderia dar início a um tratado de felicidade, infelicidade, beleza ou loucura. Mas cansei-me, vou me deitar depressa antes que o mundo se desmorone sobre meu corpo cheio de silêncio (CANÇADO, 2016a, p. 169).

Compreendemos então que a dor expressa no seu diário instaura, entre a autora e o seu próprio texto, entre a autora e o leitor, o seu caráter político ${ }^{52}$ e a aproximação de sua experiência psíquica. Esse aspecto assume maior dimensão quando sua escrita nos obriga a ir além das suas palavras, interrogando-nos essa "'marginalidade' da condição da experiência comum a todos, dimensão que rompe com os limites estabelecidos pela norma da razão" (BIRMAN, 2016, p. 31). Em algumas passagens, seu texto dá uma impressão de grito, em que

\footnotetext{
${ }^{50}$ Maura dá voz e textura ao que não existe para a sociedade "normal" de seu tempo.

${ }^{51}$ Assim é Maura: um corpo não disciplinado, não dócil, um corpo que não se corrige. Esse é um traço de sua transgressão às regras sociais. Conforme as reflexões de Foucault (1999 [1987], p. 163), o corpo dócil é um "corpo que se manipula, se modela, se treina, que obedece". E a respeito dessas "relações de docilidade-utilidade" (1999 [1987], p. 164), lembremo-nos que as escolas, os manicômios e as prisões, e tantas outras instituições sociais, cuja finalidade é exercer alguma espécie de controle dos indivíduos, seguem um regime normativo que lhes impõem limitações, proibições ou obrigações. Um bom exemplo desse controle dos corpos se realiza por meio do conceito de "disciplina" como estratégia normatizadora.

${ }^{52} \mathrm{O}$ diário da autora é, sem dúvida, um espaço de transgressão.
} 
as palavras ganham um peso especial, na medida em que questões como, quem sou eu, quem é o outro, acabam por construir a trama metafísica de sua escrita, conforme observamos no seguinte excerto:

10-2-1960 [...] Estou perdida no meu mundo de depois. Estou só, como o prenúncio do que virá tarde demais. Sinto na carne meu desconhecimento da dor. Ele enlaça-me, fere-me, busca matar-me. E se ainda não morri é porque não encontrou em mim o humano. Avanço, cega e desnecessária - não é este o meu tempo. Fora da vida, do mundo, da existência - apesar de enclausurada. Que sou eu? Não importa. Quem poderá julgar-me? - Neste mundo vazio encontro-me tranquila - angustiada. Obrigada a marchar como os outros, aparentando ser o que não sou, ou perturbo a ordem. Regredir é minha preocupação permanente. Dançar como os que me cercam (CANÇADO, 2016a, p. 171).

Como pudemos notar, a autora quando reflete sobre sua condição é convocada a retornar ao passado e experimentar momentos de perturbação vivenciados pela experiência da dor: "O que me traz para aqui? Será desejo de justiça? Analiso cada passo meu. Sofro cada gesto. Odeio estar aqui - mas vim. O medo de estar só me levaria a morar com os mortos" (CANÇADO, 2016, p. 55). Dessa perspectiva, Márcia Moreira Custódio (2017, p. 26-27) estrutura que a linguagem estética de Maura, "reforça o valor ético, na medida em que atribui à escrita um efeito expressivo mais incisivo ao trauma, na ânsia de expressar um misto de sentimento que possa mimetizar o terror, a opressão, a falta de voz”. Seguindo tal linha de raciocínio, podemos dizer que Maura imprime, pois, movimento, dor e presença no seu diário. Sendo assim, verificamos que a narrativa é construída de forma mais consciente na medida em que a autora reconhece em si mesma a presença da loucura; e a esse movimento, nos transposta ao passado revelando as origens de seu drama psíquico ao fazer menção ao "corpo cheio de silêncio" (CANÇADO, 2016a, p. 169), sinalizando-nos os indícios de sua condição e a sua inquietação com o mundo. Essa situação aumenta o seu desespero:

15-1-1960 [...] Não me agrada estar comprometida com alguém, constantemente, ou com alguma coisa. Faço literatura se desejo, não possuo disciplina, ignoro esquema de trabalho, abomino que me imponham deveres para com as coisas que me agradam. Venho sozinha para o hospício; se me obrigassem, lutaria com todas as minhas forças para não vir. Naturalmente faz parte da minha esquizofrenia esta maneira de ser (CANÇADO, 2016a, p. 148).

É nessa direção que a autora vai erigindo os elementos da loucura que compõem o universo do hospício, a partir dos quais podemos perceber a ausência, o esquecimento e a 
distância: “15-11-1959 [...] O hospício nos dá oportunidade de fazer tudo o que lá fora não nos é permitido (talvez aí esteja a chave: não suporto lá fora)" (CANÇADO, 2016a, p. 53).

Dessas considerações, importa ressaltar um aspecto sobre a intencionalidade da escrita íntima: esse tipo de escrita, como mencionado acima, também exige do autor um compromisso estético (FAEDRICH, 2013, p. 128). Assim sendo, Vasconcellos (2016, p. 36) observa que, "mesmo quando sabemos que um poeta utiliza em sua obra experiências que viveu, esse material será elaborado em uma estrutura retórica que o transformará". Transpondo-nos para os escritos de Maura Lopes Cançado, embora seu discurso se materialize no plano da realidade, não é possível desconsiderar os artifícios narrativos da ficção, pois a experiência da escrita torna-se objeto de arte. Nesses termos, Vasconcellos descreve a construção retórica da voz presente no texto:

Ao assumirmos o discurso, criamos um ethos, uma persona - em todo discurso, mesmo naquele que é confessional, e nesse sentido a ideia de "despersonalização" de Eliot parece-nos fecunda. Submetemo-nos, nesses atos de fala mediados pela cultura e frutos da cultura, a regras de gêneros, adequação da escolha lexical etc. (2016, p. 36).

Vasconcellos acrescenta ainda, que à escrita subjetiva, a questão se há ou não sinceridade, deve ser matizada. Nas palavras do autor:

mesmo que o crítico tenha certeza de que determinada vicissitude do que se narra ou se descreve é factual (e leituras biografistas se concentram muitas vezes nessa questão), ao entrar na rede discursiva submete-se aos mecanismos "impessoais" que regem o discurso (2016, p. 36).

Partindo dessas considerações, o que mais nos chama atenção é que além de questionar o papel das instituições psiquiátricas, a autora nos conecta com esse espaço e com o olhar dos pacientes que ali estão, os quais são traduzidos também pela sensibilidade e beleza (SCARAMELLA, 2010), campo que as palavras não conseguem atravessar. Uma cena que merece ser retratada é quando Maura descreve sobre a performance lírica de Dona Georgiana:

19-11-1959 [...] Possuía olhos azuis brilhantes, todo o rosto bonito e expressivo, aquele rosto surpreendente de louca. Estava sempre em grandes crises de agitação, andando desvairada pelo pátio, incomunicável, os pés descalços, geralmente suja de lama - seminua. [...] Dona Georgiana, recortada no meio do pátio, cantava - e era de doer o coração. As dementes, descalças e rasgadas, paravam em surpresa, rindo bonito em silêncio, os rostos transformados. Outras, sentadas no chão úmido, avançavam as faces inundadas de presença - elas que eram tão distantes. Os rostos fulgiam por 
instantes, irisados e indestrutíveis. Me deixava imóvel, as lágrimas cegandome (CANÇADO, 2016, p. 61).

Essa passagem nos permite identificar com relativa segurança que a presença de seu corpo, quando no momento da escrita do diário, quebra com o silêncio e nos conecta com um movimento que nos posiciona entre o passado, presente e futuro. Partindo dessa análise, se a escrita subjetiva pode ser encarada como um laboratório literário, a comunicação entre autor e leitor é também considerada, pois sabendo da condição de seu diário ser publicado, Maura escrevia com a presença de um leitor implícito. Sobre esse aspecto, a narrativa da loucura é, segundo Monique Plaza (1990, p. 113), uma escrita-testemunho, a qual desperta, em duas instâncias, o interesse do leitor: primeiro, porque "ele descobre o que representa a loucura para quem lhe viveu intimamente os horrores"; segundo, porque, ainda que seja tocado pela experiência do outro, aos seus olhos, essa experiência lhe parece ser desconcertante. O leitor, portanto, percebe, de certa maneira, uma realidade distópica que lhe causa estranhamento. Seguindo essa perspectiva, Monique Plaza atesta o fato de que:

A loucura pode penetrar na escrita sem suscitar a rejeição do leitor, quando é posta à distância, aclimatada. Um autor tem duas possibilidades para produzir um texto sobre a loucura que não seja julgado louco: pode testemunhar a sua própria loucura, dar conta, de forma crítica, das divagações e dos prazeres que ela lhe trouxe, ou construir uma ficção literária onde a aventura da loucura se instala e se desenrola (1990, p. 113).

É sob esse contexto que procuramos desenvolver a análise da representação da loucura na escrita de Maura Lopes Cançado, baseando-nos na ideia de que a linguagem se reveste de uma função outra, qual seja, a de romper com os limites do silêncio na literatura e na vida: seja no espaço do hospício (por meio da escrita), ou da autoanálise (como instrumento construído a partir da percepção de si mesmo), ou mesmo pelo testemunho (como denúncia). E isto Maura faz com os recursos do próprio corpo como um signo que se move - é o corpo que dá vida à sua voz e, por consequência, à sua subjetividade. Nesse sentido, as páginas do seu diário, objeto de nossa análise, exige de nós, leitores, uma constante interação na medida em que sua escrita nos tira do lugar comum - de leitores-espectadores -, para torna-nos testemunhas de um lugar que é preenchido pelo vazio da consciência. Assim, ler Maura é ressignificar o exercício da sua escrita por meio de uma consciência crítica, bem como recuperar a sua voz, que durante muitos anos esteve silenciada; é adentrar um universo antes nunca atravessado, dentro desse espaço que é o manicômio; é, sobretudo, ler o diário da autora pela perspectiva feminina sobre a insanidade. 
Seguindo o embalo dessas reflexões, importa agora conhecer a relação entre antropologia e literatura em Hospício é Deus, com o objetivo de refletir sobre o caráter literário da escrita etnográfica. 


\title{
4 DO FAZER LITERÁRIO À ESCRITA ETNOGRÁFICA
}

\begin{abstract}
3-1-1960 Meu diário é o que há de mais importante para mim. Levanto-me da cama para escrever a qualquer hora, escrevo páginas e páginas - depois rasgo mais da metade, respeitando apenas, quase sempre, aquelas em que registro fatos ou minhas relações com as pessoas. Justamente nestas relações está contida toda minha pobreza e superficialidade. Não sei como alguém, como eu, pode reagir da forma com que faço. Será deveras lastimável se este diário for publicado. Não é, absolutamente, um diário íntimo, mas tão apenas o diário de uma hospiciada, sem sentir-se com o direito a escrever as enormidades que pensa, suas belezas, suas verdades. Seria verdadeiramente escandaloso meu diário íntimo - até para mim mesma, porquanto sou multivalente, não me reconheço de uma página para outra. Prefiro guardar minhas verdades, não pô-las no papel (CANÇADO, 2016a, p. 131-132).
\end{abstract}

Quando Maura Lopes Cançado faz alusão à publicação de seu diário e declara o não reconhecimento de si mesma ao ler os seus escritos, estamos conscientes de que a escritora se vale de artifícios literários para a composição de sua obra Hospício é Deus, colocando assim em evidência um dos pontos centrais quanto aos limites entre arte e vida na escrita sobre o eu. No entanto, essa discussão, acerca da intenção da publicação, não invalida o discurso da autora, que é fruto de uma vida que foi traçada por recorrentes entradas e saídas em clínicas psiquiátricas.

Nesse sentido, para além do caráter estético de sua narrativa, o qual transforma o diário em obra literária, o efeito da escrita de Maura, como já vimos nos capítulos anteriores, se configura nas reflexões às críticas e denúncias às instituições psiquiátricas, sobretudo, ao suposto saber médico, pondo em xeque seu caráter humanitário para com aqueles que sofrem de problemas mentais. Com isso, a escritora não escreve para falar tão somente de si mesma, mas, nos mostra, em várias passagens de seu diário, as agruras e violências de um sistema excludente que, segundo Michel Foucault (1999 [1987]) não se constitui como espaço de cura, mas de controle de corpos enquanto discurso.

E ao descrever e traduzir a realidade do hospício pela palavra escrita, Maura, ao que tudo indica, realiza o que conhecemos como escrita etnográfica. A esse modo, reconhecemos em seu diário uma vivência antropológica, por entendermos que a Antropologia tem como objetivo, em seu sentido mais amplo, estudar as culturas dentro de um contexto específico, cujas ferramentas de estudo se realizam por meio do trabalho de campo e da etnografia, esta entendida como sendo um tipo de descrição da cultura observada. Desse modo, a etnografia é uma área de estudo que tem como ponto de partida produzir interpretações culturais através de intensas experiências de pesquisa (CLIFFORD, 1998), o que significa dizer que a escrita 
etnográfica, assim como o diário, traduz para a forma textual, a experiência do outro e de si mesmo.

\section{1 O FAZER LITERÁRIO EM HOSPÍCIO É DEUS}

Hoje não é. Mas existo desmesuradamente, como janela aberta para o sol. Existo com agressividade (CANÇADO, 2016a, p. 92).

Nesta seção, interessa-nos a estetização da linguagem do diário de Maura, com o intuito de investigar o processo criativo da autora na escrita confessional.

Paulo Sérgio de Vasconcellos (2016), ao destacar um dos momentos importantes na história da recepção moderna da poesia amorosa romana escrita em primeira pessoa, aponta os estudos do classicista Archibald W. Allen, no que diz respeito ao conceito de "sinceridade" na poesia antiga. Segundo este autor, não é possível fazer referência ao conceito de sinceridade entre os antigos romanos, tal como o entendemos em sua versão moderna. Para Allen, a noção de fides, conceito que advém da retórica, embora se assemelhe a concepção de sinceridade, revela, de certo modo, um significado diferente, se aproximando mais de uma aparência de verdade - a verossimilhança. A seguir esse raciocínio, Vasconcellos esclarece que:

Fides implica um pacto entre um falante e seu destinatário, um contrato baseado na verossimilhança, não uma fidelidade à realidade vivida. $\mathrm{O}$ discurso deve parecer verdadeiro, isto é, ser verossímil, independentemente de uma ligação com a experiência concreta do seu enunciador. Trata-se, então, de obter, pelo discurso, uma impressão convincente de sinceridade (2016, p. 35, destaque do autor).

Desse modo, entendemos que fides é o conceito que mais se aproxima da ideia moderna de "persuasão" (VASCONCELLOS, 2016, p. 35) e ambos os conceitos estabelecem um pacto entre o nome de autor com o receptor. Isso significa dizer que por mais que uma poesia possa revelar as experiências do autor empírico, o crítico sabe que se trata de um poema em que o autor joga com a capacidade inventiva da linguagem. Assim mesmo, é imprescindível ao poeta, a eficácia e a prática de fazer do discurso um exercício literário se utilizando de técnicas e procedimentos que se aproximem do real (ARISTÓTELES, 1973).

Em termos modernos, quando um autor deseja narrar, em primeira pessoa, a história de sua vida pela escrita, recuperando fatos e episódios de toda uma vida, ou aspectos dela que 
considera importante relatar, temos o pacto autobiográfico ${ }^{53}$. Philippe Lejeune (2008) confere ao termo em questão as relações de autenticidade entre autor, narrador e leitor. Porém, se neste tipo de pacto há um compromisso com a verdade, o conceito de fides, por outro lado, se caracteriza como efeito de real, buscando o autor não o compromisso com a verdade concreta, mas os meios que viabilizem a criação de artifícios discursivos para compor uma verdade, haja vista que "em literatura, a própria sinceridade é, apenas, uma jogada de estilo" (LEMINSKI, 2012, p. 106).

Mas quando falamos em autobiografia, seguindo os passos de Lejeune (2008), pensamos também no caráter literário desse gênero. $O$ crítico francês considera que os procedimentos narrativos da ficção e do relato autobiográfico muito se assemelham, contudo, o que difere a autobiografia da ficção, é que aquela se preocupa em algum momento, ainda que de forma implícita, sinalizar o leitor de que a história contada é de fato verídica, não existindo o jogo da dissimulação. Lejeune alega ainda que, essas sinalizações podem ocorrer de inúmeras formas, tais como as referências aos elementos paratextuais do livro, as notas prévias, os motivos que levaram ao escritor a tal exercício, dentre outros. Ou seja, para que haja um pacto autobiográfico, existe antes uma espécie de ritual em que a autenticidade da narrativa é assegurada ao leitor. Entretanto, não podemos dizer que a autobiografia não comporta o ficcional, pois sabemos que todo ato de narrar traz consigo as linhas imaginárias de nossas rememorações. Além disso, o que separa a autobiografia do romance ficcional é o que Lejeune concebe como o pacto romanesco, em que não há a referência direta das experiências do autor. Neste tipo de pacto, o texto é lido apenas como ficção, não havendo, portanto, o compromisso com a verdade.

Retomando Vasconcellos (2016, p. 36), o ponto mais importante a ser observado acerca da questão se há ou não sinceridade nos escritos de primeira pessoa, é que nós, leitores mais críticos, mesmo sabendo que um escritor transmita em seu texto as experiências que viveu, essa escrita, em certa medida, já não pertencerá ao seu autor, porquanto ela será transformada em matéria literária. Comenta Vasconcellos que:

[...] está em questão o caráter mimético do discurso de ego. O poeta elegíaco assumiria a persona, a máscara, de um apaixonado, a cuja fala deve-se adequar certo tipo de discurso. [...] Ego num texto literário não é o autor, mas algo que resulta de uma série de fatores, inclusive a tradição genérica e a cadeia discursiva em que o texto se situa (2016, p. 36).

\footnotetext{
${ }^{53}$ Como vimos em capítulo anterior, o pacto autobiográfico é um contrato de enunciação e de leitura. Assim sendo, esse contrato tem valor de garantia de autenticidade entre autor e leitor, em que o autor assegura ser sincero quando afirma ter vivido aquilo que é narrado por ele.
} 
Nesse sentido, é possível depreender que a todo escritor, em determinado momento de sua composição - seja este um poema, um relato de viagem ou uma simples descrição de uma paisagem -, isto é, em toda a sua trajetória como produtor de um discurso autorreferencial, busca, de maneira consciente ou inconsciente, os artifícios literários que sejam capazes de mimetizarem o real. Por essa razão, a questão sobre a relação ars/uita na poesia amorosa latina é colocada em cena por Vasconcellos (2016, p. 37), ao constatar que nos estudos contemporâneo, a poesia dos antigos, escrita em primeira pessoa, levanta a questão da persona poética muito fortemente. Inclusive, a corrente da New Criticism, como vimos, foi também uma influência notavelmente marcante nos estudos literários, pondo em xeque a pertinência de leituras biografistas dos textos ${ }^{54}$.

O que nos interessa nessa discussão é a questão de como abordar o tema da relação ars/uita na escrita sobre o eu no contexto contemporâneo da escrita do diário de Maura Lopes Cançado, em que as instâncias entre realidade e ficção se mesclam.

Num primeiro momento vemos que a composição da obra Hospício é Deus - Diário I estabelece uma relação de identidade entre a autora, a narradora e a personagem, firmando, desse modo, um contrato entre autor e leitor por meio do pacto autobiográfico, segundo o postulado de Philippe Lejeune (2008). Uma vez admitido essa relação entre autor e leitor, aceitamos que sua escrita não se desvia do compromisso em representar uma vida que fora difamada nas diversas esferas sociais.

Hospício é Deus é, assim, caracterizado como um gênero híbrido, no qual encontramos memórias, diário e autobiografia, o que resulta, afinal, em um artifício discursivo do qual a autora faz uso, buscando convencer o seu leitor do relato ali exposto. Para refletirmos sobre as diferenças entre essas três instâncias que constituem o livro de Maura, recorremos à Sheila Dias Maciel, em seu artigo "A literatura e os gêneros confessionais" (2004) que diz assim:

Apesar das semelhanças indiscutíveis entre autobiografias, memórias e diários (todas formas autobiográficas centradas na figura de um narrador em primeira pessoa que se revela), podemos situar um espaço mais ou menos preciso para cada uma destas possibilidades de escrita confessional, mesmo conhecendo as dificuldades de encontrar o caráter distintivo entre formas tão próximas (sem paginação).

\footnotetext{
54 "Para que o poema realmente se tornasse um objeto em si, a Nova Crítica tinha de separá-lo tanto do autor quanto do leitor" (EAGLETON, 1997, p. 64).
} 
Assim sendo, o estudo dessas três formas de narrativas escritas em primeira pessoa, revela claramente a estreita relação que cada uma tem com a outra, sendo difícil delimitá-las precisamente. Paralelamente a isso, não podemos ignorar que em seu processo de escrita a autora faz uso de uma linguagem elaborada, na qual encontramos, nos dizeres de Vasconcellos (2016, p. 59-60), "uma disjunção entre experiência concreta do autor empírico (uita) e o que se diz na obra de arte". Nesse ponto, Maciel (2004) argumenta:

$\mathrm{O}$ que garante a um texto sua entrada e permanência dentro do universo literário, da qual o diário faz parte, é menos sua tendência ao autobiografismo puro ou à sua total entrega à força realizadora da ficção, mas seu compromisso com o apuro da linguagem (s/p).

É oportuno lembrar que em qualquer instância da enunciação, em que um eu se dirige a um leitor, José Luiz Fiorin (2008, p. 157) considera que, "o discurso não é apenas um conteúdo, mas também um modo de dizer, que constrói os sujeitos da enunciação", ou seja, o leitor é também o produtor do discurso, "na medida em que determina escolhas linguísticas do enunciador" (2008, p. 157). Por essa razão, a eficácia do discurso em qualquer modo narrativo, seja ele ficcional ou não, está diretamente ligada à questão de como o leitor incorpora o éthos do narrador. Daí a importância das escolhas do autor, acerca das características discursivas, ao construir sua narrativa a fim de apreender as imagens do seu leitor com o fito de alcançá-lo.

Nesse sentido, ao articular a narrativa de seu passado com o seu presente, descrevendo aspectos desde o momento da infância até as vivências nas instituições psiquiátricas, Maura se utiliza da memória como uma das estratégias literária para a criação de sua obra. Essencialmente, o recurso à memória pode, muitas vezes, não ser realizado de maneira consciente, mas, no momento em que a autora decide contar sobre o seu passado, descrevendo em pormenores suas experiências, e desejando iluminar pontos de sua vida, ela entra no jogo da memória. Ademais, com o objetivo claro de justificar sua condição de mulher louca, Maura se vê impelida a buscar no passado os motivos que a colocaram nessa condição. É esse, afinal, o papel que o passado irá exercer na sua escrita, ativando uma memória de como se procedeu o processo de sua loucura.

Uma vez mais, a fim de compreender melhor os limites da arte e da escrita na construção da narrativa de Hospício é Deus, comecemos pela análise do artifício da memória.

Ao focalizar a rede discursiva de seu passado com o objetivo de buscar as respostas para o seu sofrimento psíquico, entendemos que Maura não consegue apreender tudo aquilo 
que vivenciara, haja vista que "é impossível transpor qualquer realidade fielmente retratada para a página escrita" (MACIEL, 2004, s/p). Ou seja, no momento em que desejamos revisitar o passado, uma nova narrativa é reconstruída, visto que a nossa memória está profundamente atrelada ao exercício da imaginação criativa. E é por meio desse retorno ao passado que a escrita de si pode auferir contornos ficcionais, o que significa dizer que nesse processo encontramos um espaço que permite abrir caminhos para a fantasia, o ilusório e a criação. Conforme ela diz: "28-10-1959 [...] Tudo se mostra impreciso em minha natureza nebulosa e difícil. Tenho impressão de que me renovo a cada instante" (CANÇADO, 2016a, p. 38).

Seja como for, ainda que a vontade de ser plenamente fiel aos episódios vividos, na narrativa somos de alguma forma traídos pela nossa imaginação. Nas palavras de Maciel (2004, s/p): "as memórias são uma busca de recordações por parte do eu-narrador com o intuito de evocar pessoas e acontecimentos que sejam representativos para um momento posterior, do qual este eu-narrador escreve". Tal reflexão reitera a ideia de que não é possível voltar às lembranças do passado sem antes compor uma nova imagem daquilo que foi vivido um dia.

A esse respeito, comenta Daniela Aparecida Batista (2010, p. 60) que, o diário de Maura "abre espaço para a reflexão do seu próprio fazer textual". Vejamos uma passagem do diário, em que a escritora reencena uma parte da sua vida, recuperando as memórias dos tempos em que morava em Belo Horizonte, que segundo ela, foi um dos motivos que a levou a procurar a instituição psiquiátrica:

22-11-1959 [...] Morava em pensionatos de estudantes, comportava-me normalmente. As moças, tão minhas amigas no princípio, ao descobrirem meu frustrado casamento, passavam a evitar-me. $\mathrm{E}$ as freiras exigiram logo minha mudança. Vivi durante muito tempo em hotéis familiares, e só quem conhece a mentalidade dos mineiros é capaz de saber o que quer dizer "familiar" em Minas. Se os homens me achavam bonita, imediatamente os donos dos hotéis exigiam minha mudança. Se me faziam a corte e não eram correspondidos, contavam na gerência a longa noite de orgia que haviam passado comigo (CANÇADO, 2016a, p. 66).

Nesse fragmento, podemos observar que a escrita de Maura é direcionada para um interlocutor quando relata em seu diário as experiências que tivera de quando estava morando em Belo Horizonte, "ainda que esse destinatário não esteja implicado nos acontecimentos" (BRAIT, 2017, p. 84, grifo da autora). Identificamos aqui um dos recursos da memória, na qual a autora, na tentativa de justificar o presente sombrio projetado pelas paredes do 
hospício, expõe sua interioridade pela narrativa, a qual descreve e caracteriza, num tempo passado, a personagem Maura. Tal narrativa é, portanto, centrada no conflito feminino da mulher da década de quarenta e cinquenta - caso essa mulher não viesse a corresponder aos padrões de comportamento esperados dela. Consequentemente, foi o que aconteceu com Maura: o conflito da mulher-divorciada, expresso no relato, implica elementos sociais e culturais do momento evocado, o qual marcou fortemente a vida da autora-personagem, sendo impedida de viver numa sociedade que estigmatiza a mulher nessa condição.

Com evidência, à medida que descreve sobre um passado distante, a autora se aproxima da escritura autobiográfica, a qual se configura como um documento que permite compreender o passado, a sociedade e o pensamento de um determinado momento histórico ${ }^{55}$, a partir do ponto de vista de um eu-narrador. Assim, enquanto o diário é visto como "uma tentativa de guardar o presente" (MACIEL, 2004, s/p), a autobiografia, por sua vez, esboça uma narrativa em que um "eu" faz um relato da própria vida. E assim, a memória é evocada por essas instâncias narrativas, em que a autora vê-se impelida a justificar a sua condição presente, marcada pela solidão e angústia, como é descrito no seguinte fragmento:

16-12-1959 Aos vinte e dois anos vim para o Rio. Gastara toda minha herança. Pensava seriamente em trabalhar; entretanto, diziam-me, a maneira mais "decente" de viver, sendo jovem, bonita e sem dinheiro, seria à custa de um amante rico. Vivi um ano com muito dinheiro, em completo desequilíbrio psíquico. Não aceitava aquela situação, talvez pela minha formação burguesa, mas, acredito, sobretudo, talvez pela minha dependência financeira. Sempre ameaçada por uma crise, tomada por completa depressão (passava vinte ou mais dias trancada em meu apartamento de hotel, ouvindo música e chorando), ou muita exaltação, fiz um eletroencefalograma, que acusou disritmia cerebral generalizada. Um ano depois meu estado pareceume desesperador. Fui a um psiquiatra, pedi-lhe para internar-me num sanatório. Concordou e fui. Internei-me na Casa de Saúde do Alto da Boa Vista, de onde meu médico era diretor. Frequentada por pessoas agradáveis, a Casa de Saúde era belíssima, elegante. No grande hall jogávamos sinuca, bilhar, pingue-pongue e cartas. Eu me vestia com muita elegância. A princípio pareceu-me divertido. Em breve, deixei-me tomar por profunda insatisfação e tédio, passei a desejar mudar-me de sanatório (CANÇADO, 2016a, p. 106-107).

${ }^{55}$ Os dilemas e conflitos vivenciados por Maura, até o momento de sua entrada no hospício, são reflexos de um ideal de mulher definido "a partir dos papéis femininos tradicionais - ocupações domésticas e o cuidado dos filhos e do marido - e das características próprias da feminilidade, como instinto materno, pureza, resignação e doçura" (PINSKY, 2017, p. 608-60, destaque da autora). Esse ideal de mulher foi cultivado pela família burguesa das últimas décadas do século XIX e da primeira metade da década do século XX. 
Nessa passagem, temos também como fio condutor o retorno da escritora ao passado, quando ela narra as suas experiências do período em que estivera internada no sanatório particular. Assim sendo, ela esclarece os motivos que a levaram a procurar tal instituição, expressando pela palavra escrita o drama de quem vive a dor existencial. Além de narrar a si mesma como uma mulher da alta sociedade, que saiu do interior a fim de resolver a vida na cidade grande, Maura se exercita na descrição de uma jovem elegante, frágil e entediada, representação essa típica da mulher descrita nos folhetins romanescos do século XIX. Desse autorretrato, encontramos, então, a Maura que desfruta de uma vida confortável, que segundo ela, foi também proporcionada pelo seu rico amante. E como paciente dessa casa de internação, comporta-se caprichosamente com aqueles do seu convívio. Isso fica mais evidente no relato abaixo, quando ela descreve:

Um hóspede do sanatório, sr. Monteiro, sem nenhum desequilíbrio mental, semiparalítico, julgava-me uma artista frustrada. Incentivava-me a escrever. $\mathrm{Se}$ eu quebrava coisas, ele me dava ainda mais coisas para quebrar. Percebendo que eu estava sempre representando, quis montar uma peça de teatro, onde eu seria a personagem principal. Adaptou convenientemente o Hamlet, a personagem principal passou a ser Ofélia. [...] Se minha família estava longe, meu rico amante dava-me toda assistência. Eu era egoísta, caprichosa, necessitava de atenção a todo instante, mas todos cediam diante de minhas vontades, a começar pelos médicos. Até chegar a tarde na cachoeira: durante um ensaio do Hamlet, senti-me estranha, aborrecida e desconfiada, todos pareciam conspirar contra mim. Apanhei o livro da peça, encaminhei-me para uma cachoeira, perto do sanatório (esta passagem está descrita no meu conto "Sonifene"). Nesta cachoeira desempenhei um dos maiores papéis de minha vida, ameaçando atirar-me de grande altura, ficando nua, achando-me muito bonita, e terminei lançada e arrastada por uma corda depois de três horas de rogos para que eu saísse de lá. Assim, Ofélia foi salva, nua, das águas da cachoeira. [...] Hoje, depois de conhecer hospitais do Governo, e haver sofrido pelas menores "faltas" cometidas, avalio o quanto fui bem tratada naquele sanatório. [...] Agora, compreendo que o dinheiro suaviza tudo: até a loucura. Nos últimos hospitais que frequentei não tive uma crise que ao menos se aproximasse desta. Mas, com o tratamento dispensado, não resistiria, estou certa (CANÇADO, 2016a, p. 108-109).

Essa descrição da realidade do hospício como sendo um lugar "romântico", onde é "possível" seguir a risca alguns comportamentos reprováveis de mulher louca e mimada, que caímos no universo da linguagem de tal forma que, ao apreender como a personagem Maura pensou inicialmente o espaço do hospício, compreendemos melhor as nuances de sua interioridade e a sua relação com o mundo (BRAIT, 2017, p. 20). Nesse caso, o agir de modo intransigente e vaidoso, seja quebrando objetos na casa de saúde, seja pulando do alto de uma cachoeira, é que nos chama a atenção em se tratando de Maura Lopes Cançado. Ela reforça 
constantemente esse perfil social, construído pela literatura romântica, ao descrever a imagem de si mesma como uma mulher inteligente, bela, triste e entediada, que viveu reclusa numa elegante clínica psiquiátrica com pessoas gentis, afirmando, precisamente, o quanto fora mimada nesse hospital. Ela diz: “16-12-1959 [...] diante dos meus desatinos, mostraram-se [as senhoras] condescendentes [...]. Atirava pratos e copos no chão, escandalizava a todos, descendo seminua para o hall, quando conversavam em paz e descanso" (CANÇADO, 2016a, p. 107, destaque meu).

E dessa realidade de interna, consequência de uma existência que ameaçava os princípios morais e os bons costumes da sociedade mineira das décadas de 1940/1950, e da qual the causou angústia e sofrimento, Maura constrói um jogo em que por vezes aceitamos como realidade o que é apenas linguagem. Não à toa que a escritora revela seu comportamento falseador, ao afirmar que está sempre representando um papel, o que nos permite confirmar o seu compromisso com a literatura, em virtude dessa vida que, de acordo com Vasconcellos (2016, p. 58), “joga com a capacidade da escrita de criar uma fícção que pode ser tomada como realidade". Ela confessa:

15-1-1960 [...] Estou brincando há muito tempo de inventar, e sou a mais bela invenção que conheço. Antes me parecia haver um depois. Agora não me parece haver além de agora. Há muito tempo o tempo parou. - Onde? Sou o marco do esquecimento (CANÇADO, 2016a, p. 149).

Nesse trecho, observamos nitidamente o "jogo vertiginoso da relação ficção versus realidade" (VASCONCELLOS, 2016, p. 64) empregado pela narradora para dissimular o seu leitor. Se nos adentrarmos mais nesse jogo, poderemos deduzir que tudo o que foi narrado em seu diário não passa de uma história puramente ficcional, como também é indicado no fragmento abaixo:

4-1-1960 [...] Incapacidade quase total de escrever. Lapsos. Terei resistência para escrever um romance? Há longos vazios em minha mente que me tornam difícil formular uma história. Se me fosse possível escrever mais rápido, e sem as interrupções. Estou sempre cansada, disposta a deixar tudo para começar depois (CANÇADO, 2016a, p. 134).

Entretanto, é através da literatura que o discurso de uma mulher "louca" pode exercer sua plena liberdade, expressando as verdades que, fora desse contexto, poucos ousariam escutar. 
Estamos aludindo, portanto, à persona de Maura, que em literatura representa uma função da linguagem - lírica ou narrativa -, e que por vezes está associada à imagem da máscara teatral. Isto é, ao se revestir de uma máscara, a autora assume uma personagem que fala sobre a própria loucura, expressando opiniões, sentimentos e emoções, com o objetivo claro e preciso de dar o seu testemunho sobre o que ocorre por detrás das casas de internação. No entanto, Vasconcellos (2016, p. 56) salienta que é preciso termos cautela quando pensamos no conceito de persona. Segundo o estudioso, "falar em persona não deve significar rejeitar de imediato qualquer possibilidade de haver alguma vivência pessoal no que relata o poeta em primeira pessoa". A julgar pela persona em Maura, não significa dizer que o eu da autora não se identifica com o eu da personagem, pois mesmo se expressando claramente in propria persona, as experiências descritas podem não ser necessariamente da autora. Ela pode, inclusive, escolher o papel mais adequado a si ou enunciar pensamentos coletivos, justamente por se identificar com o grupo de sua comunidade, que é o manicômio. Muitas vezes, esses recursos são procedimentos típicos de quem utiliza da intenção para produzir, em seus escritos, narrativas que sustentem o real. Nessa lógica: "a teoria da persona, então, pode ser vista como uma análise dos diferentes aspectos do caráter humano e de como eles se ajustam para produzir os resultados finais" (DICK, 1996, p. 270 apud VASCONCELLOS, 2016, p. 172).

É necessário, desse modo, levar em conta que, no caso da autora, a persona serve como um artifício enunciativo oferecido pela linguagem, a fim de dar materialidade e consistência à construção do seu discurso. E é por meio dessa persona que Maura critica veementemente os valores tradicionais da sociedade, em razão das inúmeras discriminações que sofrera devido às consequências de seus comportamentos considerados desviantes para a mulher de seu tempo, tais como pilotar um avião e a sua condição de divorciada. Assim, por não cumprir com as expectativas sociais que faziam parte da sua realidade, como ser uma boa mãe e uma esposa dedicada, o efeito disso foi às internações, inicialmente voluntárias, nas clínicas psiquiátricas: “28-10-1959 [...] Sinto medo. Minha vida não é importante, não sou imprescindível a alguém. Ao contrário: consideram-me inútil, até perniciosa. Socialmente não tenho nenhum valor" (CANÇADO, 2016a, p. 37).

De início, Maura pensou ser a casa de internação um lugar que a acolheria da dor do mundo, porém, percebeu estar equivocada ao sofrer com a dura realidade desse lugar, principalmente após a mudança para os hospitais do governo. Nesse caminho, ela denuncia os mecanismos coercitivos das instituições psiquiátricas e faz com que de fato conheçamos os verdadeiros tratamentos dispensados aos que sofrem de problemas mentais. A despeito disso, 
a autora demonstra claramente ter consciência sobre a importância da sua voz narrativa, a qual, sem dúvida, pressupõe um leitor em mira, o que, consequentemente não é esperado de um diário íntimo. Ela nos convida à reflexão sobre o espaço de opressão que é o hospício:

$1^{\circ}-2-1960$ [...] Fui hoje ao pátio com Isabel. Não creio que a descrição do inferno, na Divina Comédia de Dante, possa superá-lo. Ocorreu-me, quando estava lá, pensar na tranquilidade dos cemitérios. A toda família é tolerável e às vezes confortador visitar o túmulo de um parente. Mas é proibido entrar no pátio de um hospício. Nenhuma família resistiria, estou certa. [...] Até quando haverá pátios? Mulheres nuas, mulheres vestidas - mulheres. Estando no pátio não faz diferença. Mas esta mulher, rasgada, muda, estranha, um dia teria sido beijada. Talvez um bebê lhe sorrisse e ela o tomasse no colo, por que não? Não aceito nem compreendo a loucura. Parece-me que toda a humanidade é responsável pela doença mental de cada indivíduo. Só a humanidade toda evitaria a loucura de cada um. Que fazer para que todos lutem contra isto? Não acho que os médicos devam conservar ocultos os pátios dos hospícios. Opto pelo contrário; só assim as pessoas conheceriam a realidade, lutando contra ela. ENTRADA FRANCA AOS VISITANTES: não terá você, com seu indiferentismo, egoísmo, colaborado para isto? Ou você, na sua intransigência? Ou na sua maldade mesmo? Sim, diria alguém, se pudesse: recusaram-me emprego por eu ter estado antes internado num hospício. Sabe, ilustre visitante, o que representa para nós uma rejeição? Posso dizer: representa um ou mais passos para o pátio (CANÇADO, 2016a, p. 159-160).

Postura consoante com um discurso transgressor, a autora propõe, em seu diário, uma análise reflexiva acerca dos limites da condição humana, material e sensível - para dentro e fora das paredes do hospício -, extraindo das suas experiências e das experiências do outro, “indagações que redimensionam a existência por meio da linguagem" (MACIEL, 2004, s/p). Como a narrativa transcorre em forma de denúncia sua escrita toca profundamente a essência humana, se dirigindo não só aos leitores curiosos, que porventura desejam conhecer o que ocorre por detrás dos muros do hospício, mas, especialmente, se dirige àqueles que contribuíram para a sua condição de desequilibrada: Maura critica a moral burguesa e religiosa, bem como as instituições sociais que determinam o modo de ser do indivíduo em uma sociedade. Significativamente, no instante em que a autora medita à publicação de seu diário, tal escritura é destinada à materialização em objeto artístico.

Assim, partindo da premissa inicial de quem escreve um diário não o faz com a intenção de publicá-lo, observamos que Hospício é Deus não se enquadra, precisamente, na definição de diário íntimo, embora suas páginas introduzam as marcações de datas ${ }^{56}$. O fato é que, estando imersa na realidade do hospício e assumindo o papel de jornalista do Suplemento

\footnotetext{
${ }^{56}$ Da edição da obra em estudo, as marcações de datas iniciam-se na página 26. Antes disso, temos um breve resumo de seu passado, o relato autobiográfico.
} 
Dominical do Jornal do Brasil, a autora escreve consciente da possibilidade de suas anotações serem publicadas ${ }^{57}$. Lembramos, a esse respeito, que Maura publicava contos e poemas nesse jornal, e em diversas passagens de seu diário, ela comenta sobre alguns de seus contos ${ }^{58}$ :

17-12-1959 [...] Escrevi um conto, publicado no Suplemento Dominical do Jornal do Brasil - "Introdução a Alda". Esta pessoa, Alda, existe, está internada neste hospital. Deve ser doente há mais de vinte anos. Apena, seu nome é Auda, minha querida dona Auda. E não Alda, como julguei. Quando a conheci, há três anos, dormíamos no mesmo dormitório. Não sei exatamente por que, me impressionava profundamente. Dr. A. perguntou-me a razão dessa simpatia, e respondi-lhe: "Não sei bem, mas ela parece não necessitar mais de ninguém" (CANÇADO, 2016a, p. 113).

Como lemos, Auda foi percebida por meio do famoso conto "Introdução a Alda". É dentro dessa dinâmica normativa, que insiste em excluir as diferenças, que a autora insere outras vozes narrativas ao lado da sua, dando palavra para quem não tem voz. Aliás, esse é outro elemento discursivo do qual ela se utiliza, que é tirar do silêncio a fala dessas mulheres, sugerindo uma pequena leitura biográfica através dessas personagens inscritas nesse espaço de reclusão e sofrimento. Comentando a importância da sua escrita, Maura sublinha: "Muitos disseram que, depois do meu conto - que foi lido e relido aqui - a condição de Alda se transformou neste hospital, e pude constatar. Pelo menos consegui chamar atenção para ela, procurando mostrar que sofria" (CANÇADO, 2016a, p. 113-114).

Desse esforço de contestar os valores sociais, a autora também se utiliza da loucura como estratégia narrativa, como mostraremos nas próximas seções. Por isso, ler com a perspectiva de que o que está sendo dito é, de fato, a história do que aconteceu à autora e às outras internas, especialmente em se tratando de uma confissão da loucura, é meditar sobre o espaço da escrita que permite reescrever a história, não em termos de uma vida, mas, de outras tantas vidas.

\footnotetext{
${ }^{57} \mathrm{E}$ antes mesmo de seu diário ser publicado, ele havia sido anunciado em algumas páginas dos importantes cadernos culturais daquele período. Foi o diário que a tornou conhecida pela crítica literária da época.

${ }^{58}$ Ao mesmo tempo em que recupera seu discurso, que fora silenciado pela sociedade, a menção aos contos que produzia no jornal, é, possivelmente, uma das estratégias utilizada por Maura, com o objetivo de divulgar sua obra.
} 


\subsection{ETNOGRAFIA}

Talvez devesse escrever um conto para cada doente, se isto viesse melhorar-lhes a sorte (CANÇADO, 2016a, p. 99).

Saindo, em princípio, do universo do fazer literário, que é o centro desta dissertação, seguimos com os estudos da Antropologia, campo das ciências humanas que tem como premissa o estudo do ser humano e suas diferenças. Nosso interesse é apresentar sucintamente esse saber, objetivando analisar o papel de Maura Lopes Cançado enquanto observadoraparticipante da realidade das instituições psiquiátricas. Em nosso entender, a escrita do seu diário Hospício é Deus, lhe confere a persona de pesquisadora dentro do espaço do hospício, no qual a autora nos transporta sua visão de mundo, reportando-nos à realidade da loucura. Sendo assim, a antropologia nos oferece subsídios para reflexões sobre a experiência e o discurso de Maura, para quem cumpre um importante papel político ao demarcar também as relações entre diferenças e desigualdades das instituições que procuram disciplinar os indivíduos que fogem às regras sociais. Essas considerações, ainda que breves, contribuem para o entendimento de sua escrita, a qual foi produzida a partir de um trabalho que decorre da observação e da complexidade das experiências entre o eu e o outro.

Em linhas gerais, nossos estudos demonstram que a percepção de que existem diferentes culturas, sociedades e costumes é antiga. Antes mesmo da antropologia se constituir como um saber específico ${ }^{59}$, a qual ganhou status científico na metade do século XIX, em decorrência da observação das diferenças entre as sociedades humanas e da reflexão sobre elas, a palavra é usada desde o Renascimento. Assim, antropologia, na acepção grega, é o estudo do homem nos seus diversos aspectos. O historiador Allan de Paula Oliveira (2018, p. 49) explica que:

Em um primeiro momento, ela tinha o sentido de um estudo no plano biológico e anatômico do homem (traços fisiológicos, como tamanho do crânio). Por volta do século XVII, ela começou a ser usada para denotar um estudo do homem no sentido mais filosófico, ligado à ideia iluminista de uma humanidade dotada de razão em potencial.

59 "A cristalização da antropologia refere-se ao processo pelo qual a antropologia se constituiu como um saber específico, separado de outros, como a história, a filosofia e a sociologia" (OLIVEIRA, 2018, p. 46). 
À medida que se estabeleceu, nesse século, como uma disciplina voltada aos estudos das diferenças humanas, a antropologia foi marcada por alguns conceitos que se tornaram centrais em sua história. Todavia, por reconhecermos a amplitude e a profundidade desses conceitos, os quais escapam aos limites desta dissertação, nos detivemos apenas no conceito de cultura. Não à toa que esse termo é frequentemente relacionado aos estudos da Antropologia, cuja disciplina é definida como a ciência que estuda as culturas, apesar de esse conceito não ser exclusivamente um conceito antropológico, haja vista que outras disciplinas também produziram reflexões sobre ela, tais como a Sociologia, a História, a Psicologia, entre outras. Desse modo, em razão da sua importância para o nosso entendimento sobre a etnografia, vale destacar a ideia de cultura presente no século XX. De acordo com Oliveira (2018, p. 89):

[...] o conceito de cultura, durante o século XX, estava relacionado, sobretudo, às formas pelas quais as sociedades dão sentido ao mundo, sendo um domínio da vida humana que opera tanto no nível da ação quanto no do pensamento. Então, a cultura passou a ser vista como uma espécie de lente pela qual os seres humanos enxergam o mundo e agem sobre ele.

Nesse sentido, a ideia de cultura que emergiu entre os anos de 1890 e 1930, é aquela que leva em conta o contexto da experiência de uma sociedade. Isto é, os estudos que se debruçam sobre uma sociedade tomam em consideração os detalhes da vida social, as formas de pensar, as crenças, os costumes, o contexto dos fatos, entre outros. De acordo com esse pensamento, cada sociedade tem seu sentido próprio, ou seja, sua própria cultura, a qual só pode ser plenamente compreendida em seu contexto particular. Logo, o contexto passou a ser o ponto de atenção entre os antropólogos, sendo que a cultura, inicialmente pensada como expressão singular, passou a ser definida não mais nesse aspecto - como ocorreu no século XIX e mesmo nos primeiros trinta anos do século XX -, mas na compreensão de culturas, no sentido plural. Com isso, a antropologia pôde ampliar o seu olhar ao pensar sobre a diversidade humana, desde o instante em que considerou o sujeito enquanto ser plural. E nisso vemos, portanto, a cultura como produtora de sentido, razão pela qual essa concepção teve seu significado expandido na década de 1950, em virtude das correntes da antropologia que surgiram nesse período. Nesses termos, a cultura passou "a denotar a dimensão simbólica da vida humana" (OLIVEIRA, 2018, p. 88). Isso somado às outras áreas do conhecimento como a filosofia, a psicanálise e a linguística, as quais foram igualmente importantes para essa percepção de cultura como um novo universo de significados e símbolos. 
Aqui, nos é oportuno esclarecer que a prática de observação e descrição de uma cultura diferente já se fazia presente desde a Antiguidade. Ao longo da história, muitos estudiosos e viajantes construíram seus relatos de viagens, ou mesmo fizeram de suas vivências uma literatura de aventuras ao se encontrarem diante de novas realidades. Mas foi no século XVIII que a prática minuciosa dos registros e descrições de outras sociedades e culturas recebeu o nome de etnografia. Segundo a etimologia da palavra, etno significa povo e grafia significa registro. De modo geral, esse termo é definido como a descrição do modo de vida de uma sociedade.

Consequentemente, enquanto a antropologia se definia como ciência no século XIX, houve, nesse mesmo século, uma sistematização da prática etnográfica enquanto método científico. Isso porque o trabalho de campo realizado pelo etnógrafo não estava vinculado à vivência do antropólogo. A maneira como eram feitos os registros dos povos e das culturas pesquisadas eram realizadas pelo etnógrafo, cuja figura era de fato a responsável por coletar esses dados, para, depois, entregá-los ao antropólogo, o qual formulava proposições e teorias a partir dos dados obtidos ${ }^{60}$. Pouco depois, certos antropólogos, entre 1890 e 1930, passaram a iniciar seus caminhos de pesquisa de maneira independente e, dessa postura, a antropologia definiu melhor os modos de trabalho de campo, associando a prática etnográfica com a do antropólogo. A rigor, quando o conceito de cultura foi sendo aos poucos modificado, passando a denotar uma realidade plural, a questão da extensão do contato do pesquisador com a cultura pesquisada tornou-se importante. E a partir disso, os antropólogos perceberam que o contato profundo entre pesquisador e a sociedade estudada se faz imprescindível, de tal modo que, para que haja um efetivo aprendizado das culturas observadas, deve haver a inserção de longo prazo nessa cultura.

Em resumo, a antropologia formulou proposições que deram um caráter moderno à etnografia, a qual, por sua vez, se constituiu como um modo de trabalho da antropologia. Desse modo, a etnografia, tal como será apresentada neste capítulo, é uma experiência que advém da antropologia pós-moderna, mais, precisamente, da antropologia social e cultural, e que veio a ser concebida como um modo de pensar e escrever sobre a cultura de um grupo social a partir do ponto de vista da observação-participante - termo este que será explicado mais à frente. Sobre a prática etnográfica, nos apoiamos nas reflexões do antropólogo Clifford Geertz, para quem nos esclarece que:

${ }^{60}$ Essa prática foi assim realizada em razão das sociedades estudadas pertencerem aos domínios dos impérios coloniais no século XIX. De acordo com Oliveira (2018, p. 126): "a obtenção direta dos dados poderia ser feita pela própria burocracia colonial ou por missionários na forma de questionários e entrevistas". 
Em antropologia ou, de qualquer forma, em antropologia social, o que os praticantes fazem é a etnografia. E é justamente ao compreender o que é a etnografia, ou mais exatamente, o que é a prática da etnografia, é que se pode começar a entender o que representa a análise antropológica como forma de conhecimento. Devemos frisar, no entanto, que essa não é uma questão de métodos. Segundo a opinião dos livros-textos, praticar a etnografia é estabelecer relações, selecionar informantes, transcrever textos, levantar genealogias, mapear campos, manter um diário, e assim por diante. Mas não são essas coisas, as técnicas e os processos determinados, que definem o empreendimento. O que o define é o tipo de esforço intelectual que ele representa: um risco elaborado para uma 'descrição densa', tomando emprestada uma noção de Gilbert Ryle (1989, p. 15).

Com efeito, nosso objetivo é pensar sobre a atividade de escrita etnográfica, seguindo também os passos do historiador e antropólogo James Clifford (1998), para quem propõe uma reflexão acerca do fazer etnográfico em sua dimensão literária. Em suas palavras, "a etnografia está, do começo ao fim, imersa na escrita. Esta escrita inclui, no mínimo, uma tradução da experiência para a forma textual" (CLIFFORD, 1998, p. 21).

Assim, sendo a escritora Maura Lopes Cançado interna de um hospício, condição essa que a situa dentro do quadro de pessoas que necessitam de tratamentos e cuidados para a saúde psíquica, ela assume, ao mesmo tempo, uma posição distanciada dessa realidade, ao descrever a loucura de si e do outro por meio da escrita do diário. Sobretudo no que tange aos comportamentos de médicos e funcionários, delatando suas práticas abusivas nas instituições psiquiátricas. Nos termos da antropologia, Maura realiza um trabalho de campo ao interpretar essa realidade, a qual desafia as normas da razão. E desse cenário, "o trabalho de campo etnográfico permanece como um método notavelmente sensível” (CLIFFORD, 1998, p. 20).

\subsection{JORNALISMO INVESTIGATIVO DE MAURA}

Então, por que se tem medo de um hospício? (CANÇADO, 2016a, p. 27).

Conforme nos esclarece os estudos de Maria Luisa Scaramella (2010, p. 46), a escritora mineira Maura Lopes Cançado se tornou conhecida em vinte e quatro de agosto de 1958, quando estreou no Suplemento Dominical do Jornal do Brasil com um poema de canto de página. Em seguida, passou a fazer pequenas publicações de contos e poemas em prosa, entre os anos de 1958 e 1961. Em 1968, alguns contos foram publicados em uma coletânea intitulada $O$ Sofredor do ver, seu segundo livro. 
Como já acenamos no primeiro capítulo, o Suplemento Dominical do Jornal do Brasil, o SDBJ, era uma coluna de artes e literatura criada em 1956 pelo editor do jornal Reynaldo Jardim, e seu período de publicação foi de junho de 1956 a dezembro de 1961. Sendo um caderno cultural, o Suplemento tinha como viés artístico a experiência de vanguarda, associada ao movimento concretista, voltando-se para temas e acontecimentos do mundo da arte daquela época. O objetivo, em uma palavra, era vislumbrar o novo no campo artístico nacional, e, igualmente no contexto cultural mundial. Seu quadro era então formado por artistas, escritores, intelectuais e críticos literários, tais como Assis Brasil, Ferreira Gullar, Mário Faustino, Maria Alice Barroso, Almícar de Castro, dentre outros. Nesse sentido, ser colaboradora nesse semanário voltado para as artes e a literatura naquele período, conferia visivelmente grande prestígio em um cenário de "efervescência artística, literária e crítica no Brasil" (SCARAMELLA, 2010, p. 71), já que grandes nomes compunham o quadro do jornal.

De acordo com Scaramella (2010, 46), Maura conseguiu realizar o seu desejo de tornar-se escritora, quando ela conheceu o jornalista Sebastião de França na pensão em que morava no Rio de Janeiro. Esse jornalista foi quem apresentou Maura para o colega e crítico literário Assis Brasil. Em entrevista com o crítico, Scaramella registra que: "Ao ser apresentada a Assis Brasil, este não encontrou objeções diante do aviso de Sebastião de França sobre sua colega de pensão ser "louca", respondendo-lhe prontamente: então somos dois!" (2010, p. 72, grifo da pesquisadora). Na ocasião, já fazia seis meses que Maura não comparecia ao Hospital Gustavo Riedel. Antes de seu retorno, ela passou a frequentar ${ }^{61}$ a redação do jornal para escrever como colaboradora e, muitos dos contos que produziu são referidos no diário, os quais foram publicados aos poucos no Suplemento. "12-12-1959 Meu conto "O sofredor do ver" 62 foi publicado na primeira página do Suplemento Dominical do Jornal do Brasil. (Suplemento Dominical é o Suplemento Literário: SDBJ.) Saiu lindo, ocupou toda a primeira página" (CANÇADO, 2016a, p. 100-101).

No entanto, a obra que lhe auferiu maior prestígio foi o livro Hospício é Deus, publicado em 1965. Esse livro, misto de memórias, autobiografia e diário, foi escrito na sua terceira internação no Hospital do Engenho de Dentro, no Rio de Janeiro, onde ela relata os momentos decisivos de sua vida, tais como a infância, o casamento e as experiências nos sanatórios. E desde o momento em que entrara para o jornal, Assis Brasil, Ferreira Gullar e Reynaldo Jardim tornaram-se os padrinhos da autora, abrindo-lhe caminhos no universo literário. Em seu diário, Maura relata o desejo de escrever um livro:

\footnotetext{
${ }^{61}$ De volta ao Hospital Engenho de Dentro, Maura tinha passe livre para sair do hospital e ir ao jornal.

${ }^{62}$ Título de mesmo nome da coletânea.
} 
16-11-1959 [...] Gostaria de escrever um livro sobre o hospital e como se vive aqui. Só quem passa anonimamente por este lugar pode conhecê-lo. E sou apenas um prefixo no peito do uniforme. Um número a mais. À noite, em nossas camas, somos contadas como se deve fazer com os criminosos nos presídios. Pretendo mesmo escrever um livro. Talvez já o esteja fazendo, não queria vivê-lo (CANÇADO, 2016a, p. 58).

O pensamento da autora demonstra clara intenção de publicar um livro, o que nos leva a inferir, uma vez mais, que ela sabia que seus escritos seriam publicados. Por isso, o ponto mais interessante de sua condição de interna de um hospital psiquiátrico é, que, através da escrita, Maura adapta-se a uma persona que faz denúncias dentro desse espaço onde se confinam pessoas que não se adequam às regras sociais. Tais afirmativas nos ajudam a compreender Maura como uma escuta jornalista, considerando-se que, ao descrever as experiências das instituições psiquiátricas brasileiras, ela torna público o caráter corretivo desse corpo social - composto por médicos, funcionários e, também, pelas autoridades públicas -, que, para Foucault (1999 [1987], p. 164), é responsável por promover métodos que permitem o controle minucioso dos corpos e das mentes do indivíduo. E quase sempre, esses métodos consistem em práticas que ferem contra os princípios da dignidade e dos direitos humanos ${ }^{63}$. Ela anuncia: "5-12-1959 [...] Farei o retrato de cada um em relação às doentes: os retratados serão os médicos. Sou obrigada a restringir-me aos que trabalham nas seções das mulheres; é onde estou naturalmente" (CANÇADO, 2016a, p. 89).

Cremos, então, que Maura se dotou de duas personae, isto é, duas "máscaras": uma é a da condição de louca que a distancia das normas da razão; a segunda persona seria a de jornalista, "valendo-se do status de contista que a tira da massificação manicomial" (MUSILLI, 2014, p. 80). Assim, entendemos que a autora levou para o hospício o contexto jornalístico a fim de desempenhar um papel consentâneo com a razão, de forma crítica e laboriosa, próprio da função de jornalista investigadora, como observamos a seguir:

30-11-1959 [...] o médico, depois de rotular um indivíduo de irresponsável, inconsciente, exige deste mesmo indivíduo a responsabilidade de seus atos, ao mandar (ou permitir que se faça) castigá-lo. De que falta pode ser um louco ser acusado? De ser louco? É o que venho observando e sentindo na carne. Dr. A. afirma que as guardas são ignorantes, têm muitos problemas, são também neuróticas ou loucas. Naturalmente os médicos também têm

${ }^{63}$ Como observa Foucault (1999 [1987]), as instituições psiquiátricas, assim como os colégios e as prisões, impõem ao indivíduo uma relação de "docilidade-utilidade", cujo objetivo é fabricar corpos submissos, corpos dóceis. "O corpo só se torna força útil se é ao mesmo tempo corpo produtivo e corpo submisso" (p. 29). 
problemas, são neuróticos. E loucos. Mas não foram ainda isentos de responsabilidades perante a sociedade com a alegação de insanidade. Estes homens de aventais brancos, que decidem quanto à responsabilidade ou não de tantas pessoas, deviam ter o dever de se mostrar conscientes. Não poderiam jamais exigir de alguém aquilo que lhe negam. Como seja, a responsabilidade. Mas o fazem, afirmo (CANÇADO, 2016a, p. 84).

Segundo Felipe Pena (2005, p. 11), a atividade de um bom jornalista consiste em fazer boas reflexões críticas sobre sua atividade, e ainda destaca que, "a pertinência de qualquer pesquisa está nas perguntas, não nas respostas". De fato, Maura segue essa premissa, na época em que escreveu seu texto, ao contrapor a lógica que é disseminada pelos hospitais psiquiátricos - lógica segundo a qual as casas de internação são responsáveis pela garantia da assistência à saúde mental ${ }^{64}$ :

"5-12-1959 [...] com suas deficiências, ambivalências, impotências, seus problemas - ou FALTA DE PROBLEMAS - que é, nos médicos, em relação ao hospital, mais grave e comum. Geralmente o médico "não quer nada', ouço a todo instante" (CANÇADO, 2016a, p. 90).

A escritora não só questiona a postura de médicos, em razão do descaso e negligência com os enfermos, como também retrata acontecimentos, gestos e cenas, de funcionários do hospital - copeiros, enfermeiros e guardas -, refletindo criticamente sobre seus comportamentos. Trata-se, então, do espírito investigativo adequado à necessidade de que o mundo seja testemunha do espetáculo do terror que é o manicômio no Brasil. Essa é a importância que o jornalismo assume: comunicar ao mundo aquilo que é preciso saber e que muitas vezes é omisso pela sociedade. Nos termos do jornalista Felipe Pena (2005, p. 201): “O jornalismo investigativo busca a informação primária. [...] Seu objetivo é transitar pelos bastidores das notícias, arrancando o véu opaco de acontecimentos obscuros, cujos protagonistas fazem de tudo para escondê-los". Nesse ponto é que o jornalismo assume função vital - Maura oferece ao leitor a verdade sobre o que ocorre por detrás dos muros do hospício:

\footnotetext{
${ }^{64}$ Lembremos, a título de nota, que o discurso das instituições psiquiátricas tem, também aqui, suas ambiguidades: a palavra de base era a de ordem, que, preconizava a cura segundo o viés da normatização, de modo que as considerações acerca do sujeito que sofre de transtornos mentais eram marcadas por práticas excludentes, conotando negativamente a ideia de cura. Seguindo essa linha de raciocínio, o sujeito deveria ser retirado de seu meio social para ser internado no hospital psiquiátrico, que, por sua vez, seria o responsável por exercer a função de cura desse indivíduo, para, mais tarde, devolvê-lo no seu "perfeito juízo" à convivência social. Na prática, esse retorno não acontecia, porque os processos terapêuticos à época reforçavam o abandono e os maus tratos dos pacientes.
} 
12-11-1959 Já briguei duas vezes com as copeiras. São uns monstros de estupidez. Se falamos baixo, com delicadeza, respondem aos berros. Detesto o refeitório. Creio que todos o detestam. Imenso: duas mesas de pedra cinzenta, os bancos também de pedra. As mesas nuas. Tem-se impressão de necrotério, qualquer coisa relacionada com defunto. A fila de mulheres passa por um balcão onde cada uma apanha seu prato, já preparado. Além do prato de alumínio (gorduroso e sujo), um outro menor de sobremesa e colher (a ninguém é permitido comer de garfo). Gostaria de não sentir fome. É humilhante, como nos chiqueiros. Isto mesmo: comparação exata: jeito de necrotério, sanha de porcos, necrofagia. Não sei exatamente o número. Mais ou menos trezentas mulheres. Mal se entra no refeitório se sente o cheiro. Cheiro de gente, gente sem se lavar. Algumas mulheres denunciam nos vestidos manchados de sangue a higiene exigida e desprezada aqui. E o cheiro. Cheiro de mulheres. Mulheres menstruadas e sem asseio. Procuro comer às pressas, sem mastigar, os olhos baixos evitando ver. Geralmente, é quase infalível, há uma ou mais brigas. Voa tudo pelos ares: pratos, colheres, copos de leite. Algumas doentes sobem nas mesas, metem os pés nos pratos das outras. Comidas pelo chão, guardas gritando. Arrrrr. Sempre aparecem homens, guardas ou doentes, seguram as doentes mais agitadas, torcem-lhes os braços para trás, dão-lhe gravatas, deixando-as roxas, sem respiração. As guardas andam tontas, soltando guinchos e berros. Mas quando a doente está presa, puxam-lhes os cabelos, ajudando a empurrá-la para o quarto-forte. [...] Em geral a internada não reage. Tudo passa despercebido (como tudo de errado aqui dentro), a vítima deixa o refeitório sem tomar refeição, não faz queixa, permanece com fome até o dia seguinte. São estas coitadas que as guardas classificam de "boazinhas" (CANÇADO, 2016a, p.47-49).

Vemos, pois, que ao fazer parte da comunidade do hospício, Maura serve-se de instrumento de crítica e testemunha da história da psiquiatria brasileira, apontando as incongruências desse sistema que rompeu com os princípios éticos e humanitários, ao colocarem em prática medidas de tratamentos incoerentes com aquilo que denominavam como sendo terapêuticos. Sem dúvida, essa aproximação da autora com a realidade da cultura do hospício adquire uma significação relevante na narrativa, na medida em que ela exerce esse poder de observação:

12-11-1959 [...] A verdade é que ninguém se incomoda com os maus-tratos dispensados aos doentes. As guardas dizem que devemos nos sentir felizes por temos o que comer. (Naturalmente não me dizem isso). Ah, se dissessem. Médicos não sabem se comemos ou não. Sim: POR QUE $O$ MÉDICO VAI SE PREOCUPAR COM A SENSIBILIDADE DO DOENTE MENTAL? ELES GOZAM DE PERFEITA SAÚDE, PRINCIPALMENTE MENTAL. GOZAM REALMENTE OS MÉDICOS DE PERFEITA SÁUDE MENTAL? É a questão. Se me tornar escritora, até mesmo jornalista, contarei honestamente o que é um hospital de alienados. Propalam uma série de mentiras sobre estes hospitais: que o tratamento é bom, tudo se tem feito para minorar o sofrimento dos doentes. E eu digo: É MENTIRA. Os médicos permanecem apenas algumas horas por dia nos hospitais, e dentro dos consultórios. Jamais visitam os refeitórios. Jamais visitam os pátios. O médico aceita, por princípio, o que qualquer guarda afirma. Se é 
fácil desmentir um psicopata, torna-se difícil provar que ele tem razão. Em prejuízo de um considerado "não psicopata". Que é um caso a estudar: as guardas deste hospital são quase todas loucas. Ou oligofrênicas (CANÇADO, 2016a, p.49).

Assim como é central a denúncia à sociedade e às instituições psiquiátricas, agindo refletidamente sobre os papéis centrais de cada uma delas, não é errado dizer que Maura cumpria a função de jornalista do SDBJ, ainda que ela não tivesse vínculo formal de trabalho. Não estamos longe em afirmar que esse era também um possível método de trabalho, mesmo que ela estivesse "presa" às circunstâncias de uma trajetória de vida, que, a impôs, num certo sentido, ao mundo das internações. Maura fornecia importante material para o jornal, mesmo que o SDBJ se ocupasse em tratar de assuntos culturais. Porém, sabemos que a literatura também se ocupa da realidade social, a qual é reconstruída pela escrita, colocando "em cena aquilo que os jornais eram impedidos de publicar ${ }^{65 "}$ (MUSILLI, 2014, p. 31). Assim, por exemplo, o retrato das denúncias feitas no hospício é assimilado tematicamente pelo universo literário.

\section{4 DIÁRIO DE CAMPO E HOSPÍCIO É DEUS: A ESCRITA E A REPRESENTAÇÃO DA ALTERIDADE}

O louco é divino, na minha tentativa fraca e angustiante de compreensão. É eterno (CANÇADO, 2016a, p. 25).

No primeiro ${ }^{66}$ capítulo do livro Obras e vidas: o antropólogo como autor, Clifford Geertz (2009, p. 11) nos esclarece que a concepção tradicional de etnografia, a qual é baseada na apreensão de "fatos estranhos e irregulares", para, depois, dispô-las em "categorias familiares e ordenadas", não é mais aceita nos estudos antropológicos. Essa visão, durante muito tempo, contribuiu para fomentar o preconceito entre as culturas diferentes, por estar ancorado na concepção de etnocentrismo ${ }^{67}$, termo que significa apreender o mundo pelo

\footnotetext{
${ }^{65}$ Vale aqui lembrar que o livro de Maura foi publicado no início da ditadura. Nesse período, muitas editoras destacaram-se pelas ideias e posições progressistas, não se intimidando com publicações de títulos polêmicos.

66 "Estar lá: a antropologia e o cenário da escrita".

67 "O termo etnocentrismo remete ao julgamento de valor de determinada sociedade, de suas práticas e de suas ideias, do ponto de vista da sociedade à qual o observador pertence. Trata-se de julgar os outros a partir de nós. Nesse sentido, o etnocentrismo é uma atitude extremamente presente na relação entre as diferenças humanas, diante das quais pode surgir uma série de representações e ações, como preconceitos, incompreensões e, no limite, conflitos violentos" (OLIVEIRA, 2018, p. 73).
} 
centro de nossa própria cultura. Entretanto, mesmo superada essa ideia de que não existe uma cultura superior em relação à cultura observada, ainda hoje, de acordo com o autor, não parece ser muito claro o entendimento do que seja a etnografia - o pensamento mais recorrente entre aqueles que realizam o trabalho de etnógrafo produzindo os textos, e entre aqueles que os consomem, é que "talvez a etnografia seja uma espécie de escrita, um colocar as coisas no papel ${ }^{68 "}$ (GEERTZ, 2009, p. 11). Dito de outro modo, a etnografia, é, neste sentido, entendida como uma reconstituição fiel dos fatos - e por este motivo, o autor ressalta que certos antropólogos consideram que a construção dos textos etnográficos deve esmerar-se nas descrições apenas, não havendo a necessidade em preocupar-se com o modo que é narrado. Além disso, acreditam que é preciso um grande número de detalhes culturais para que o texto possa ser aceito como verdade, caso contrário, o texto não será lido como científico, mas como um romance: o mais importante, para esses estudiosos, é que esses textos sejam convincentes.

Contudo, essa visão sobre a escrita etnográfica é problemática, posto que "a experiência está intimamente ligada à interpretação" (CLIFFORD, 1998, p. 36). Naturalmente, podemos dizer que esse pensamento é válido para todas as esferas do saber humano, assim como o é para os estudos da antropologia. Quando o etnógrafo faz uma leitura sobre uma realidade, é evidente que na descrição de seu relato, os fatos, eventos e interpretações serão construídos, "a partir de estilos intuitivos de sentimento, percepção e inferências" (CLIFFORD, 1998, p. 36). Ignorando, desse modo, que esse processo subjetivo também faz parte da prática etnográfica, muitos antropólogos não levam em conta a experiência da linguagem nesse tipo de escrita que, segundo Geertz, é extremamente significativa:

\begin{abstract}
A capacidade dos antropólogos de nos fazer levar a sério o que dizem tem menos a ver com uma aparência factual, ou com um ar de elegância conceitual, do que com sua capacidade de nos convencer de que o que eles dizem resulta de haverem realmente penetrado numa outra forma de vida (ou, se você preferir, de terem sido penetrados por ela) - de realmente haverem, de um modo ou de outro, "estado lá". E é aí, ao nos convencer de que esse milagre dos bastidores ocorreu, que entra a escrita (2009, p. 15).
\end{abstract}

Essa discussão gira em torno da referência de autoridade etnográfica, ou, autoridade experiencial, que, em linhas gerais, é a pessoa que traduz para a escrita a sua singular experiência com a cultura em contato (CLIFFORD, 1998, p. 22). Isto é, a autoridade

${ }^{68}$ É assim que muitas vezes se compreende a etnografia: colocar no papel as informações observadas acerca da cultura estudada. 
etnográfica é o modo como o autor se coloca presente no texto. Portanto, na antropologia é importante saber quem está falando, especialmente quando se trata de um discurso de quem, pela reputação baseada no saber e na experiência, poderá melhor apreender as "estruturas de significado" (CLIFFORD, 1989) da realidade em estudo ${ }^{69}$ por meio do texto etnográfico.

Assim, destacamos que a antropologia interpretativa, nas palavras do antropólogo James Clifford (1998, p. 39), "contribui para uma crescente visibilidade dos processos criativos (e, num sentido amplo, poéticos) pelos quais objetos 'culturais' são inventados e tratados como significativos". E no momento em que os comportamentos, as falas e os costumes de uma determinada realidade em pesquisa são transformados em texto, esses elementos (objetos culturais), assumem uma relação mais ou menos objetiva, porque essa realidade é concebida como uma criação da experiência do autor e, desse modo, concluímos que sua construção é também subjetiva.

Foi pensando nisso que Geertz (2009) declarou que não existe uma compreensão clara do caráter literário que a antropologia concebe, e acredita que se houvesse tal compreensão, a questão de como a escrita antropológica pode ser convincente não existiria entre os antropólogos, uma vez que os textos etnográficos encerram em si mesmos a "substancialidade factual" (GEERTZ, 2009, p. 13). Dessa forma, o etnógrafo como intérprete da vida da cultura do outro é quem melhor desempenha a figura de autoridade etnográfica, porque "precisam convencer-nos não apenas de que eles mesmos realmente 'estiveram lá', mas ainda de que, se houvéssemos estado lá, teríamos visto o que viram, sentido o que sentiram e concluído o que concluíram" (GEERTZ, 2009, p. 29). Podemos, então, assumir que é muito difícil invalidar o discurso de quem "esteve lá"70.

Com relação à nossa autora, não temos dúvida de que ela, em todos os sentidos da palavra, "esteve lá", que, nesse caso, sabemos se tratar do hospício ${ }^{71}$. E, nesse sentido, é

\footnotetext{
${ }^{69}$ No entanto, como sabemos, toda escrita imprime o caráter subjetivo do escritor. O mesmo acontece com a escrita etnográfica. Clifford $(1998$, p. 21) afirma que, à tradução da experiência para o texto, "o processo é complicado pela ação de múltiplas subjetividades e constrangimentos políticos que estão acima do controle do escritor. Em resposta a estas forças, a escrita etnográfica encena uma estratégia específica de autoridade", visto que "uma complexa experiência cultural é enunciada por um indivíduo" (1998, p. 22-23).

${ }^{70}$ A expressão "estar lá", em antropologia, remete à presença do pesquisador (etnógrafo) no campo de atuação, que é o caminho mais importante a ser percorrido em um estudo etnográfico. Portanto, enquanto leitores, partilhamos não só da experiência e percepção do etnógrafo, como também da cultura da qual ele registra. É assim que se compreende a "autoridade etnográfica", segundo os estudos de James Clifford (1998, p. 18), quando ele diz: "O modo predominante e moderno de autoridade no trabalho de campo é assim expresso: "Você está lá... porque eu estava lá"”.

${ }^{71}$ E não só esteve, como passou a maior da parte da sua vida em instituições psiquiátricas, até o momento de sua morte.
} 
possível analisar a sua escrita na linha de raciocínio da prática etnográfica: primeiro, porque ela tem um prolongado contato pessoal com as pessoas que ela observa; segundo, e mais importante, porque mesmo na condição de paciente psiquiátrica, Maura, também como escritora, dispôs a tornar clara a sociedade do hospício a partir de uma atitude tipicamente documentária. Examinemos o trecho: "26-10-1959 [...] Uniformes cinzentos. Desfile de rostos iguais. Alguns gritos, algumas gargalhadas. Sem lágrimas, sem apelação. Medo: as portas trancadas que dão sinal de vida. As guardas rancorosas" (CANÇADO, 2016a, p. 33). Em tais circunstâncias, o relato da autora é uma espécie de milagre, considerando a sua coragem em revelar ao público os bastidores do hospício.

Uma das ferramentas fundamentais da etnografia é a escrita do relato etnográfico (relato de campo), que, por definição, consiste numa escrita capaz de descrever o percurso de atividades vivenciadas no campo de trabalho. O relato etnográfico é, portanto, o projeto final que o pesquisador converte pela escrita sua vivência do contexto percorrido e observado (SILVA, 2009, p. 186). Tentemos, agora, definir de modo mais preciso o que isso quer dizer na escrita de Maura.

A autora encena uma escrita etnográfica, que, nos termos da antropologia, tem por finalidade observar uma determinada cultura, e para que isso seja possível, "torna-se necessário ir ao lugar e permanecer ali" (NIKODIMOV, 2011, p. 86). A seguir, ela constrói "um mundo de experiências partilhada sem relação ao qual todos os 'fatos', 'textos', 'eventos' e suas interpretações serão construídos" (CLIFFORD, 1998, p. 35). E, ao cabo desse processo de tradução de sua experiência num corpus textual, "os eventos e os encontros da pesquisa se tornam anotações de campo" e "as experiências tornam-se narrativas, ocorrências significativas ou exemplos" (CLIFFORD, 1998, p. 41). Essa escrita tem, portanto, a ver com o lugar ocupado por ela e, ao levar essa escrita à publicação, ela reduz a distância entre o eu e o outro $^{72}$. Para melhor entendimento sobre a sua experiência de observação, seguimos com uma passagem, na qual Maura comenta e descreve sobre a hora do almoço das internas, enfatizando, nesse contexto, a problemática da alteridade:

26-11-1959 [...] À hora do almoço o refeitório vibra, frenético e nauseante. Uma, rasgada, dança com o prato na cabeça. Outra come ávida, mastigando de boca aberta, a gordura escorrendo-lhe pelo queixo. Falam, cantam, brigam, riem. A guarda grita. As mulheres por um instante mantêm-se assustadas e despertas; logo recaem no sono lerdo - movimentado e denso onde vozes brotam pesadas, cheias de esquecimento. O refeitório sacudido

\footnotetext{
${ }^{72}$ Que neste caso, o outro é representado pela figura do "louco". Louco posto em destaque, porque Maura faz distinção entre a loucura e aquele que sofre de transtornos psíquicos.
} 
sustenta-se fantástico. Me movo longínqua, tragada pela irrealidade que a todas confunde. Como depressa e sem prazer. Uma mulher passando por mim me esbarra. Solto um nome feio, levemente assustada com minha brutalidade, deixo o prato. Por um momento me conservo imóvel e dura, observando. Meu braço apoiado sente a frieza da mesa de pedra, sem toalha. Sim, digo para mim mesma - má e sem sofrimento - o refeitório de loucas. Mas sim, por que não dizer? E meu lábios gastos se contraem num ríctus, que não é de dor, mas de quase maldade (CANÇADO, 2016a, p. 76).

A cena retratada nos desperta a atenção, mas não apenas pelo que Maura relata a respeito das pequenas ações das internas no momento do almoço, descrevendo seus gestos e comportamentos característicos, que a seu ver, são considerados excêntricos. O depoimento chama a atenção pelo fato de que Maura olha com distanciamento para as suas colegas internas, interpretando e registrando a imagem da loucura. E ao resumir a cena como "o refeitório de loucas", faz reflexões importantes com as quais ela também se identifica. Isso é possível de ser percebido, por exemplo, quando ela sinaliza o hospício como sendo um lugar onde há o "excesso de liberdade", não existindo, em teoria, barreiras que as impedem de se lançarem numa vida sem grande decoro. Assim, dando continuidade ao excerto acima, lemos a seguinte passagem:

26-11-1959 [...] Aqui estamos nesta sarambada alucinada. Nós, mulheres despojadas, sem ontem nem amanhã, tão livres que nos despimos quando queremos. Ou rasgamos os vestidos (o que dá ainda um certo prazer). $\mathrm{Ou}$ mordemos. Ou cantamos, alto e reto, quando tudo parece tragado, perdido. [...] Nós, mulheres soltas, que rimos doidas por trás das grades - em excesso de liberdade (CANÇADO, 2016a, p. 76, destaque meu).

O que nos importa ressaltar é que a experiência da autora dentro desse universo expressivo, que é o hospício, evoca nos termos de Clifford (1998, p. 38), "uma presença participativa". Esta é uma das razões por que Maura segue, em nosso entendimento, os passos da experiência etnográfica quando ela nos introduz nesse pano de fundo nebuloso, para falar de si mesma e do outro, revelando-nos um mundo de tensões, controles e manifestações violentas. Exemplo disso é quando a autora concebe a loucura como um estado de não presença, em que o sujeito louco não consegue compreender a realidade tal como ela se apresenta diante dele, e por isto torna-se, em escala maior, alheio e distante das circunstâncias de seu entorno, como exemplificado no trecho a seguir, quando ela nos dá a imagem refletida dos abusos cometidos contra as internas no momento em que são enviadas para o pátio:

26-11-1959 [...] Saio lenta, o refeitório ficando para trás. Maria de Oliveira, a guarda, grita para uma doente que se recusa a comer "Coma, diabo. Você 
devia dar graças a Deus por esta comida. São todas umas pobres indigentes". As mulheres são mandadas para o pátio. Algumas distantes demais para compreender, permanecem quietas. As guardas empurram-nas, puxando-lhe os cabelos pelos corredores. [...] Às vezes caio em profunda depressão, as coisas externas me machucando duras, e, no íntimo, um sofrimento incolor, uma ânsia, um quase desejo a se revelar (CANÇADO, 2016a, p. 76-77).

Percebamos como a loucura, do ponto de vista da autora, é identificada como sendo um eu que se distancia de si mesmo, em oposição à consciência de si, a qual nos permite refletir e avaliar a própria condição. Referindo-se a algumas mulheres nesse estágio de consciência, relemos: "Algumas distantes demais para compreender, permanecem quietas" (CANÇADO, 2016a, p. 77). A isto se liga um dos aspectos centrais de sua obra quando ela inscreve de forma poética a expressão da loucura: "O que me assombra na loucura é a distância - os loucos parecem eternos. Nem as pirâmides do Egito, as múmias milenares, o mausoléu mais gigantesco e antigo possuem a marca de eternidade que ostenta a loucura" (CANÇADO, 2016a, p. 25).

Nesse estágio de reflexão, consideramos que a obra de Maura é também um texto filosófico sobre uma questão central no pensamento da humanidade: o que é a loucura? E ao versar sobre esta e outras questões que permeiam o significado deste conceito, ela promove "um contato sensível com o mundo a ser compreendido, uma relação de afinidade emocional com seu povo, uma concretude de percepção" (CLIFFORD, 1998, p. 38). E aqui, lemos "seu povo" como reflexo de sua experiência como paciente psiquiátrica juntamente com as outras internas.

Dando continuidade ao seu pensamento crítico encontramos Nair, para quem Maura descreve a colega como retrato fiel da realidade de seu tempo, onde era comum confinarem as mulheres em clínicas psiquiátricas pelos mais diversos motivos:

27-11-1959 [...] Nair, surda-muda, é inteligentíssima. Não a creio psicopata. Sua família a mantém aqui por um desses casos inexplicáveis de incompreensão humana. Então contaram um drama ao médico, arranjaram amigos influentes - prenderam-na como doida. (Não é o único caso aqui dentro.) (CANÇADO, 2016a, p. 78).

Nair é um daqueles casos emblemáticos de exclusão social. De acordo com os estudos da historiadora Yonissa Marmitt Wadi (2006), a respeito de histórias sobre as mulheres no hospício ${ }^{73}$, muitas delas não tinham diagnóstico de transtorno mental - eram apenas mulheres

\footnotetext{
${ }^{73}$ Os estudos de Yonissa Wadi compreendem o período entre 1884 e 1923, em Porto Alegre, no Rio Grande do Sul.
} 
consideradas indesejáveis pela sociedade. Fato é que no decorrer do século $\mathrm{XX}$, as mulheres ocuparam gradativamente a maioria dos leitos dos hospitais psiquiátricos. É o caso de dona Auda, paciente psiquiátrica no Engenho de Dentro. Seu caso de internação não era incomum no seu tempo ${ }^{74}$. Muitos homens internavam suas esposas em clínicas psiquiátricas com o objetivo claro de se livrarem delas, alegando que estavam doentes, quando na realidade não estavam. Este fato fica subentendido no trecho abaixo, no qual o retrato da loucura em Auda recebe o rótulo de mulher rebelde:

7-2-1960 [...] Há mais ou menos três dias, sentada no chão fazendo crochê, juntei-me a ela. Estávamos sós e falou-me como jamais o fez até hoje: "Oscar meu marido ameaçou trazer-me para este hospício se eu continuasse fazendo maluquices. Estive antes nos sanatórios Santa Alexandrina e Santa Helena". "Gostou deles? As enfermeiras eram boazinhas?" - perguntei.

- A mesma coisa. Algumas boas, outras más. Mas sabe, aqui parece que a gente fica pior, não acha? Eu era completamente diferente; sabia receber, frequentava festas, bailes. Agora sou uma boba. Nem sei falar, não vê?

- Não, que nada.

- É sim, menina. Pensa que não sei?

Sim, dona Auda, sei que sabe disto e muito mais. Se só temos uma vida, quantos anos a senhora perdeu desta vida. Vinte e tantos anos de $\ldots \ldots \ldots$, de quê? A quem pediremos conta do tempo roubado? Quem a lesou, e por que, dona Auda? (CANÇADO, 2016a, p. 167, destaque meu).

Nesse excerto, Maura encena a questão do conflito público-privado através da experiência de dona Auda, que foi confinada compulsoriamente no manicômio. E assim, a experiência dessa personagem se torna também a experiência de muitas mulheres que foram internadas à força por seus maridos e/ou familiares. Em verdade, há motivos históricos para essa realidade à qual, durante séculos, concebeu a loucura como sendo uma enfermidade predominantemente feminina, pois segundo Elaine Showalter (1987), as mulheres foram submetidas ao destino que a sociedade lhe designou e, como consequência, sofreram as mais diversas situações de opressão nos papéis de esposas, mães, filhas e amantes. E, não bastasse isso, eram também "mal compreendidas pela psiquiatria" (WADI, 2006, p. 68).

\footnotetext{
${ }^{74} \mathrm{Em}$ linhas gerais, compreendemos que a mulher "louca" incomoda a sociedade. Isso é o mesmo que dizer que o diagnóstico da loucura feminina, estava, frequentemente, relacionado com aquilo que não era o esperado dela pela sociedade. Ou seja, a loucura indicava algo que fugia ao que era concebido como "normal", ou, simplesmente, à desobediência a padrões sociais impostos às mulheres. Logo, as mulheres que atentassem contra a moral pública e/ou religiosa, especialmente aquelas que não sofriam as influências da figura do marido ou do pai, por exemplo, eram internadas em hospital psiquiátrico, onde receberiam tratamentos para "corrigir" os comportamentos considerados desviantes. Inclusive, o discurso médico, durante muito tempo, endossava essa postura de correção. A psiquiatria era, portanto o lugar destinado a tais mulheres tidas como transgressoras.
} 
No hospício, a mulher perde toda a sua condição de sujeito, sua identidade, torna-se submissa, é institucionalizada, não mais oferece perigo à sociedade ou à família. É importante ressaltar que, em muitos casos, as internações eram feitas pela família, por não suportarem a alteridade, a "vergonha" por determinados comportamentos ou até mesmo por questões de ordem econômica (MACHADO \& CALEIRO, 2008, p. 5).

Se, por um lado, a loucura feminina estava relacionada a não adequação dos papéis femininos estabelecidos pela Igreja e pela sociedade, por outro, esses padrões de comportamentos também contribuíram para os conflitos de ordem psíquica de muitas mulheres, o que acabavam por construir no imaginário social a identidade da mulher louca. Nesse sentido, destacamos que ao lançar a seguinte indagação, Maura constrói uma alegoria da condição feminina nesse espaço: "7-2-1960 [...] A quem pediremos conta do tempo roubado? Quem a lesou, e por que, dona Auda? (CANÇADO, 2016a, p. 167)”. A esse respeito, muito apropriadamente observou Clifford (1998, p. 65), quando esclarece que, "os textos etnográficos são inescapavelmente alegóricos, e uma aceitação séria desse fato modifica as formas com que eles podem ser escritos e lidos".

É assim, que, através da descrição sobre as colegas internas, nós a vemos em cada uma delas, a exemplo de dona Marina, que, como Maura, proveniente de família rica e tradicional, foi internada antes em clínica particular e, depois a internaram no hospital do governo, por não ser mais viável custear com os gastos da estadia. Os hospitais do governo, segundo a autora, tornam ainda difíceis a convivência de pessoas de alto nível social com as outras internas que, em sua grande maioria, são consideradas "indigentes":

- Dona Marina, como pode ficar neste pátio imundo, junto a pessoas tão desagradáveis?

- Não as vejo, menina. Estou distante. Tenho minha família, minha vida passada, tão linda. Minhas recordações. Não me encontro aqui.

Eu aparentava entender. Dona Marina sorria, em dúvida.

Agora minha companheira de quarto é ela. Não a obrigam mais a frequentar o pátio, jamais deviam tê-lo feito. Acredito que se abstraísse como dizia: é esquizofrênica. Mas como lhe deve ter custado permanecer junto àquelas mulheres, ela, tão fina, educada e culta. Considerada doente, há mais de vinte anos. Nasceu no Rio Grande do Sul, de família rica e tradicional. Antes de vir para aqui passou por sanatórios caros. Caso crônico, a família recorreu ao último recurso, internando-a em hospital do Governo, derradeira etapa da doença mental. Os sanatórios particulares são caríssimos, verdadeiros trustes da indústria psiquiátrica. Dificilmente alguma família está em condições de manter, por muitos anos, um doente internado em sanatórios desse tipo. Daí encontrarmos pessoas de alto nível social, cultural, até artístico, em meio a indigentes para os quais o hospital oferece conforto nunca antes experimentado (CANÇADO, 2016a, p. 50-51). 
Esse é um dos exemplos comoventes de "distância" que Maura define como sendo a loucura. Assim, por exemplo, ela descreve dona Marina, mulher de seus 54 anos, considerada doente há mais de vinte anos - um caso crônico de esquizofrenia. Sabe falar francês, inglês e um pouco de alemão. É também musicista e lhe permitem tocar piano somente aos domingos, durante meia hora, ainda que, como nos conta Maura, o instrumento permaneça mudo durante todo o tempo na sala do hospital. A questão da "não presença" levantada acima nos leva a perceber, uma vez mais, que a autora conseguiu apreender a sua época e seu momento histórico ao retratar esse processo de rejeição social e familiar. Toda essa clareza, luminosa e ao mesmo tempo assombrosa, faz com que ela tome nota em seus escritos a respeito da representação sobre a noção de loucura e de doença mental. Ao sofrimento de sua colega de quarto, a escritora expressa com sensibilidade uma consciência que procura fugir do vazio de sua existência. Segundo ela, dona Marina nunca confessa estar internada em hospital de "doentes mentais":

14-11-1959

- Os quartos estão caros, você não imagina. Aqui pago barato, as despesas saem mais em conta.

- Por que a senhora não está morando com sua irmã?

- O apartamento dela é pequeno.

- A senhora não pretende se mudar nunca?

- Não disse? Preciso fazer economia, menina.

Não acredito que se iluda tanto. Diz assim para mentir-se a si própria e não dar satisfação de sua vida particular. Sempre procura justificar as atitudes de sua família, nunca se queixa se não recebe visitas, mostra-se apreensiva, teme que algum mal seja a causa. Aparenta ignorar o descaso de que é vítima, e me parece mais lógico. As famílias, por mais dedicadas, terminam se cansando dos parentes loucos, a morte deles sendo mesmo um alívio (CANÇADO, 2016a, p. 51-52).

O sentido da loucura é então expresso de maneira distinta da doença mental. Para a autora, os doentes mentais são aqueles que não conseguem existir sem os seus tormentos, apontando que é a luta contra a doença que os define, a qual reafirma e reforça a sua natureza dupla: "sem lado, entre o mundo dos chamados normais e a liberdade dos outros. Não conseguem transpor o 'Muro', segundo Sartre. É a resistência” (CANÇADO, 2016a, p. 25). Ela continua:

Estar no hospício não significa ser superior. O doente, ainda preso ao mundo de onde não saiu completamente, tratado com brutalidade, desrespeito, maldade mesmo, reage. Tenta agarrar-se ao mundo de onde não saiu 
completamente. Apega-se a seus antigos valores, dos quais não se libertou tranquilo. Principalmente teme: a característica do doente mental é o medo (não o medo das guardas, dos médicos. O medo de se perder de todo antes de se encontrar) (CANÇADO, 2016a, p. 25).

O louco, por sua vez, é uma espécie de santidade, um ser divino; é aquele que consegue transcender o seu tempo e a sua realidade, vivendo sob os domínios da eternidade. Assim acrescenta Maura: "Nele não encontramos a falta. Nos parece excessivo, movendo-se noutra espécie de vibração. Junto dele estamos sós" (CANÇADO, 2016a, p. 25). Ela então observa e registra que os doentes mentais compõem a maioria no quadro do hospital, já os loucos, são poucos. E dona Marina é, na visão de Maura, classificada como louca, por ela encontrar na distância, um caminho de refúgio e liberdade:

14-11-1959 [...] Presa ao passado como sua única realidade, despreza o presente. Para ela, o presente não é. Finge aceitá-lo, um pouco irônica, condescendente diante da pequenez das pessoas que a cercam (pessoas?). Dona Marina é bem-educada a ponto de aparentar ser iludida: - Pessoas? Dona Marina sorri (CANÇADO, 2016a, p. 53).

A vida de dona Marina no hospício termina por nos conduzir a pensamentos e reflexões acerca de um sentimento humano comum a todos: a dor da solidão. E junto com a solidão, podemos sentir a experiência do abandono, a falta de amor e compreensão, sendo que, num nível mais elevado, esses sentimentos, como nos sinaliza Maura, podem alterar o estado mental do indivíduo, gerando distúrbios psíquicos, os quais acabam por levá-lo à condição de "doente mental" ou, à loucura. No caso da loucura, a descrição feita por Maura, em relação ao ser "intraduzível” e inatingível, contribui para a criação de uma imagem mística e misteriosa do sujeito louco, a exemplo de dona Auda, sobre quem ela escreve:

Dona Auda me parece um símbolo - sempre existido. Observo sua liberdade - de estar presa. Move-se independente, há uma certa dignidade intraduzível, nem sempre alcançada, em sua presença. Eles, de tão grandes, esmagam-nos. É minha impressão constante e humilhada (CANÇADO, 2016a, p. 26).

E, nesse sentido, Maura organiza a experiência de hospício em um mundo de significados: sua narrativa não se limita a descrever a si mesma ou a experiência do outro. Ela constrói uma narrativa das identidades deterioradas, destinada a revelar ao mundo o abismo para o qual o sujeito excluído é lançado.

Certamente, a narrativa em Hospício é deus, representa, em antropologia, uma performance social. Com bem observa Clifford, as histórias de Maura revelam que as "as 
performances sociais encenam histórias poderosas - míticas e também de senso comum - que proporcionam ao processo social uma retórica, "uma forma de enredo e um significado"" (TURNER apud CLIFFORD, 1998, p. 63). Assim, de acordo com o historiador, podemos encontrar na etnografia histórias impactantes que trazem consigo, "afirmações adicionais, morais, ideológicas e mesmo cosmológicas" (CLIFFORD, 1998, p. 63). A isto identificamos a performance ${ }^{75}$.

Em outras palavras, o diário de Maura, como uma escrita etnográfica, e, portanto, alegórica, é a história de uma mulher que viveu no hospício e que fala sobre a experiência da loucura, procurando refletir sobre a relação entre doença mental e padrões sociais impostos ao indivíduo, em especial, às mulheres. E todas as personagens que a autora traz para a escrita são exemplos significativos que demonstram implicações sociais e culturais na história de uma sociedade. Por isso, seus registros e sua memória visual descrevem aspectos e comportamentos que explicam estigmas ligados à loucura feminina, e o porquê das mulheres terem sido confinadas em manicômios: seja porque não queriam se casar; ou porque não queriam ter filhos; ou porque gostava de outras mulheres, entre outros motivos. Em resumo, o estigma da loucura era a mulher que transgredia as normas sociais.

$1^{\circ}-12-1959$ [...] e dona Auda: "Que fiquemos sãs e voltemos para nossos lares". [...] E se alguém nos visse ficaria também comovido. Por exemplo, dona Auda (que pede com veemência que voltemos para nossos lares): até onde ela compreende seu drama? (CANÇADO, 2016a, p. 85-86).

E assim, dona Georgiana, dona Auda, dona Marina, Durvaldina, Nair e tantas outras mulheres que Maura registra em seu diário, são como vozes específicas dentro do texto, com questões e problemas colocados na sua própria época, mas que ultrapassam os limites e o movimento do tempo. Sendo assim, a etnografia é pensada como uma "imersão profunda na alteridade" (OLIVEIRA, 2018, p. 135), de modo que, no momento em que a escritora se posiciona como espectadora do hospício, ela se inscreve na perspectiva de observadora participante, e acaba por envolver o leitor num conjunto de reflexões em que "acontecimentos singulares, assim, adquirem uma significação mais profunda ou mais geral" (CLIFFORD, 1998, p. 33). A respeito da prática sobre a representação intercultural, segue os apontamentos

\footnotetext{
75 Nessa linha de raciocínio, com o objetivo de compreender, em poucas palavras, essa lógica da performance, nos apoiamos nas reflexões do professor Richard Schechner (2006, p. 28) quando define o seu conceito: "performances marcam identidades, dobram o tempo, remodelam e adornam o corpo, e contam histórias".
} 
de Clifford, os quais se articulam com as contribuições de Mikhail Bakhtin, que escreve sobre os eventos de linguagem, entre o eu e outro:

As palavras da escrita etnográfica, portanto, não podem ser pensadas como monológicas, como a legítima declaração sobre, ou a interpretação de uma realidade abstraída e textualizada. A linguagem da etnografia é atravessada por outras subjetividades e nuances contextuais específicas, pois toda linguagem, na visão de Bakhtin, é uma "concreta concepção heteroglota do mundo" (BAKHTIN, 1953, p. 293 apud CLIFFORD, 1998, p. 44).

Como sabemos, no momento em que escreve, Maura é paciente do hospital psiquiátrico no bairro do Engenho de Dentro, no Rio de Janeiro. Seu relato é apresentado como "um produto de observação de primeira mão ${ }^{76 "}$ (CLIFFORD, 1998), descrevendo, para nós, leitores, a realidade do hospício. Isso inclui desde aspectos relacionados à sua própria experiência de interna - relatando a sua relação com o hospício, o que sente e pensa a respeito de estar nesse lugar -, como também inclui aspectos da narrativa sobre o outro, descrevendo comportamentos de pacientes, médicos e funcionários, os quais ela se posiciona em relação ao que vê e o que ouve. E foi por ter vivido durante muito tempo em hospícios, que a autora pôde desenvolver um olhar mais apurado acerca dessa realidade:

$1^{\circ}-3-1960[\ldots]$ Só o cinema será capaz de mostrar o que é o $\mathrm{IP}^{77}$. É onde são internadas as doentes na sua fase mais aguda. Depois de três meses, transferem-nas para os outros hospitais. O IP mantém um número de doentes três vezes superior ao que pode suportar. As brigas são rotina. As guardas, terríveis. Ninguém dorme: mulheres andam durante toda a noite pelos corredores, chorando, gritando, cantando e dançando macumba - ou rezando. Nos dois meses em que estive lá tinha na cabeça, continuamente, um verso de Castro Alves: "Gritos, ais, maldições, preces ressoam". Inúmeras vezes acordei sendo empurrada da cama por uma doente nua, ou com outra, imóvel, ao meu lado, completamente envolta num lençol branco. Ignoro como suportei. Realmente: ignoro como suportei. Muitas vezes fui agredida. [...] Uma vez vi uma guarda bater numa doente catatônica. Foi no banheiro, à noite, à hora do banho. A guarda bateu ajudada por uma doente, Euza. Bateu principalmente na cabeça, dando-a de encontro à parede. Nair, Eva e eu vimos horrorizadas. A doente morreu no outro dia. Não sei se no laudo médico constou como causa a agressão. Não sei se ela morreu em consequência da agressão. Mas ela morreu no dia seguinte à agressão (CANÇADO, 2016a, p. 196).

Vimos, ao longo desta dissertação, por que razões a escritora relata as faces obscuras da realidade das instituições psiquiátricas das décadas de quarenta e cinquenta. Com efeito,

\footnotetext{
${ }^{76}$ Era comum que os escritos etnográficos fossem construídos por teóricos antropólogos, e não por etnógrafos.

${ }^{77}$ IP - Instituto de Psiquiatria.
} 
“estar lá”, em se tratando da autora, implica não só viver na pele a condição de paciente, para quem experimenta momentos de perturbação vivenciados pela experiência da dor psíquica, como também implica ser testemunha dos abusos físicos e emocionais cometidos contra os pacientes. Por vezes, ela compreende e consegue sentir o sofrimento de suas companheiras internas. Ela constata: "29-2-1960 [...] É triste saber que nossos dramas são encarados com tamanha indiferença: apenas uma a mais que toma eletrochoque, sofre no quarto-forte, e outras coisas" (CANÇADO, 2016a, p. 189). Maura tem o mérito de apontar com toda clareza o desafio que representa viver no hospício ao escrever seu diário de campo e, ao fazer isso, ela "afirma uma presença" - conforme o trabalho de um etnógrafo -, ao elaborar ativamente fragmentos da realidade (CLIFFORD, 1998, p. 18) do manicômio.

Concluamos este capítulo destacando algumas conclusões a que chegamos. Nesse percurso, entendemos Hospício é Deus como sendo um diário de campo (diário etnográfico) em que consiste: no testemunho dos fatos e objetos de sua atenção; e num objeto de tomada de consciência sobre si mesma. Aqui, o ponto mais importante a ser observado é que o diário de campo é uma escrita de si que se pretende, depois, ser transformada em uma escrita oficial, que é o relato etnográfico.

Assim, por exemplo, o diário de campo é um exercício pessoal construído em paralelo com as anotações do pesquisador sobre as suas atividades na realidade em estudo. No entanto, tal finalidade, não é obrigatória, mas trata-se de um instrumento expressivo do trabalho do pesquisador, porque é no diário que nós encontramos as informações de base, que não são referidas no relato etnográfico. Isto porque no relato a tarefa do antropólogo de escrever sobre aquilo que se observa é concebida e executada de maneira diferente do diário de campo, o que significa dizer que em Antropologia, descrever aspectos culturais de uma cultura implica destacar aspectos mais objetivos no plano textual. Em outros dizeres, o relato etnográfico assume um caráter mais científico da cultura em pesquisa, enquanto que a escrita do diário é sempre subjetiva por natureza.

Segundo Geertz (2009), o diário é particularmente significativo, porque sua escrita é esboçada sob uma perspectiva ampla e diversa, e, presumivelmente, não é destinada à publicação, uma vez que:

Existe a paisagem. Existe o isolamento. [...] Existe a lembrança de casa e daquilo que se deixou. [...] E, causando mais abalo do que tudo, existem o capricho das paixões do sujeito, a debilidade de sua constituição e as digressões de seu pensamento: essa obscura coisa chamada eu. [...] A questão é viver uma vida multíplice: navegar em vários mares ao mesmo tempo (GEERTZ, 2009, p. 104). 
Em suma, a partir do momento que a autora tem a intenção de publicar seus escritos, ela está ali construindo um diário de campo. Ela está, pois, extraindo informações, ideias e, ao mesmo tempo, exprimindo sua sensibilidade ao próximo, "captando o imediato com o ardor do poeta e fazendo abstrações a partir dele com o zelo do anatomista" (GEERTZ, 2009, p. 107). A escrita de Maura consiste num vaivém permanente entre as tomadas de nota sobre os acontecimentos no hospício, e as considerações que ela faz a seu respeito, e por isso, percebemos o seu diário como uma espécie de território fluído, onde encontramos os sentimentos e o estado de espírito que dominaram a escritora, jornalista e paciente psiquiátrica em boa parte de sua vida. Isto, segundo a nossa opinião, promove material para o Suplemento Dominical do Jornal do Brasil, uma vez que Maura, assumindo os papéis de contista e jornalista, também assume a persona de pesquisadora de campo ao fazer uma imersão no universo do hospício. 


\section{CONSIDERAÇÕES FINAIS}

Hospício é Deus é uma profunda narrativa, simultaneamente sobre a vida de Maura e sobre a vida no manicômio. É também a história de um inconsciente coletivo, porque enquanto Maura fala sobre sua vida, sua permanência no hospício e sobre seus anseios enquanto escritora, põe-se a lamentar que, enquanto a humanidade cercear a liberdade de um indivíduo no tocante às diferenças, não procurando servir aos seus projetos, ela será a "responsável pela doença mental de cada indivíduo" (CANÇADO, 2016a, p. 160). Essas reflexões permitiram-nos afirmar que seu livro está diretamente relacionado com o estudo do ser humano e de seus problemas existenciais.

Da experiência psíquica da autora sentimos o peso da angústia, do medo e o sentimento de impotência para lidar com as expectativas sociais e morais. Assim, um estudo do título da obra e de sua história é, efetivamente, um estudo da relação da autora com Deus, em que o sentido de Deus é, aqui, associado aos esforços de repressão de uma classe dominante, segundo critérios autoritários, e de todo um sistema que promove e incentiva a exclusão social em seus mais diversos aspectos. Deus é, então, visto como um ser que a tudo vigia e controla, ocupando todo o espaço do hospício, e a vida de Maura. Deus é, portanto, o discurso patriarcal e, quem foge desse discurso, é visto como um estranho, um desequilibrado, um louco.

Com o objetivo de compreender melhor a história e a vida de Maura, vimos, no primeiro capítulo, que as verdades contidas na obra da autora são "verdades" que emergem dessa trama social que insiste em afirmar que o papel da mulher é procriar, cuidar da casa e do marido. Logo, a escrita do diário, nos permitiu conhecer a experiência de uma autorapersonagem que escreveu suas memórias no espaço do hospício, buscando compreender sua condição psiquiátrica. Esses apontamentos nos auxiliaram a investigar a escrita da autora dentro da esfera da loucura, em que pudemos constatar que, a loucura feminina, muitas vezes, está relacionada a não sujeição da mulher aos discursos normativos.

Posteriormente, no segundo capítulo, refletimos sobre o comportamento do texto literário em relação às experiências do autor. E aqui, pudemos identificar que a obra de Maura, dentro das instâncias narrativas das escritas de si, é construída sob três domínios narrativos: autobiografia, memórias e o diário não íntimo. E deste fato, chegamos a conclusão de que Hospício é Deus, como produto literário, foi escrito para ser publicado, e por este motivo, seus escritos fogem à concepção de diário postulada por Philippe Lejeune (2008). 
Além disso, também concluímos que o diário se configura como laboratório literário para a produção de seus contos.

Finalmente, no terceiro capítulo, procuramos analisar o livro e a experiência da autora, como uma experiência etnográfica, a qual é pautada nas reflexões da antropologia do século XX. Como vimos ao longo desta dissertação, Maura ambicionava se tornar uma escritora de sucesso. Sua iniciação literária foi como colaboradora do Suplemento Dominical do Jornal do Brasil, onde começou a publicar contos e poemas. Ao mesmo tempo, acreditamos que ela poderia fornecer importante material para o jornal ao focalizar tematicamente a realidade da loucura por meio da escrita de um diário. E desse diário, compreendido como etnográfico, a escritora geraria artigos para o jornal.

É, portanto, pela análise de sua escrita que nos cumpre dizer que, do ponto de vista da luta antimanicomial a obra de Maura é arquetípica. A autora, sem imaginar, ocuparia um importante lugar na enunciação do discurso literário e, também histórico, ao tornar-se uma das precursoras do início das lutas do movimento da reforma psiquiátrica brasileira, que ocorreria vinte anos depois. Sem dúvida, ela desempenha um importante papel quando exprime a situação social e psíquica de homens e mulheres que não conseguiram afirmar o seu valor na sociedade. Em especial as mulheres, que, por motivos históricos, foram excluídas das diversas camadas sociais e cujo destino era se não aquele dos limites do privado, o segundo lugar que lhes estava destinado certamente era o do hospício. 


\section{REFERÊNCIAS}

APARECIDA, Daniele Batista. Loucura: a temática que constrói o discurso da obra Hospício é Deus, de Maura Lopes Cançado. 107 f. Dissertação (Faculdade de Ciências e Letras de Assis) - Universidade Estadual Paulista “Júlio de Mesquita Filho”, Assis, 2010.

ARAUJO, Cinara de. Tinha medo de ver, num mesmo olhar um trem e um passarinho: a escrita íntima em Maura Lopes Cançado. 103 f. Dissertação (Mestrado em Letras: Estudos Literários), Universidade Federal de Minas Gerais, Belo Horizonte, 2002.

ARAÚJO, Gilberto. O romance em Maura Lopes Cançado. Revista brasileira. Rio de Janeiro, v. 2, n. 98, p. 117-128, jan./mar. 2019. Disponível em:

http://www.academia.org.br/publicacoes/revista-brasileira-no98. Acesso em: 04 jun. 2019.

ARFUCH, Leonor. O espaço biográfico: dilemas da subjetividade contemporânea. Tradução Paloma Vida. Rio de Janeiro: UERJ, 2010.

ARISTÓTELES. Poética. In: . Tópicos; Dos argumentos sofisticos; Metafísica (Livro I e Livro II); Ética a Nicômaco; Poética. Tradução Eudoro de Souza et al. São Paulo: Abril Cultural, 1973, p. 439-525.

ARTAUD, Antonin. Van Gogh, o suicida da sociedade. Tradução Ferreira Gullar. Rio de Janeiro: José Olympio, 2007.

ARTIÈRES, Philippe. Arquivar a própria vida. Estudos Históricos. Rio de Janeiro, v. 11, n. 21, p. 9-34, 1998. Disponível em:

http://bibliotecadigital.fgv.br/ojs/index.php/reh/article/view/2061/1200. Acesso em: 14 jan. 2019.

BAKHTIN, Mikhail. Questões de literatura e estética: a teoria do romance. São Paulo: Unesp, 1998.

BARTHES, Roland. O rumor da língua. In: . A morte do autor. Tradução Mario Laranjeira. 2. ed. São Paulo: Martins Fontes, 2004. p. 57-64.

BEAUVOIR, Simone. O segundo sexo. Tradução Sérgio Milliet. Rio de Janeiro: Nova Fronteira, 2016.

BIRMAN, Daniela. Notas sobre a marginalidade: o periférico, o agregado e o louco no campo literário. Tuttamerica, Roma, n. 161-162, p. 19-41. 2016. Disponível em: https://studylibpt.com/doc/6255921/tuttamerica.2016--edi\%C3\%A7\%C3\%A3o-completa. Acesso em: 18 abr. 2018.

BORGES, Luis Borges. O fazedor. In: Baptista. Rio de Janeiro: Globo, 1999. . Obras completas II. Tradução Josely Vianna

BRAIT, Beth. A personagem. 9. ed. São Paulo: Contexto, 2017. 
BRANDÃO, R. S. Mulher ao pé da letra: a personagem feminina na literatura. Belo Horizonte: UFMG, 1993.

BRANT, Vera. Maura Lopes Cançado. Disponível em:

http://verabrant.com.br/1/cronicas/Maura\%20Lopes\%20Cancado.htm. Acesso em: 22 fev. 2020.

BUTLER, J. Problemas de gênero: feminismo e subversão da identidade. Tradução Renato Aguiar. Rio de Janeiro: Civilização Brasileira, 2012.

CANÇADO, Maura Lopes. Hospício é Deus: Diário I. 5. ed. Belo Horizonte: Autêntica, 2016 a.

CANÇADO, Maura Lopes. O sofredor do ver. 2. ed. Belo Horizonte: Autêntica, 2016b.

CHARTIER, Roger; História cultural do autor e da autoria. In: . Autoria e história cultural da ciência. FAULHABER, Priscila; LOPES, José Sérgio Leite. (orgs.). Rio de Janeiro: Beco do Azougue, 2012. p. 37-64.

CLIFFORD, James. A experiência etnográfica: antropologia e literatura no século XX. Tradução Patrícia Farias. Rio de Janeiro: UFRJ, 1998.

COMPAGNON, Antoine. O demônio da teoria: literatura e senso comum. Tradução Cleonice Paes Barreto Mourão e Consuelo Fortes Santiago. 2. ed. Belo Horizonte: UFMG, 2012.

CORRÊA, Louise Bastos. A consciência no abismo: uma leitura da obra de Maura Lopes Cançado. 130f. Dissertação (Mestrado em Letras) - Universidade Federal do Rio de Janeiro, Rio de Janeiro, 2013.

CUSTÓDIO, Márcia Moreira Custódio. Literatura e loucura: a carnalidade da loucura de Maura Lopes Cançado em Hospício é Deus. 111f. Dissertação (Mestrado em Letras: Estudos Literários) - Universidade Estadual de Montes Claros, Montes Claros, 2014.

CUSTODIO, Márcia Moreira Custódio. A escrita de Maura Lopes Cançado: um contraponto com a (des)articulação da linguagem do louco. 222 f. Tese (Doutorado em Letras) - PósGraduação em Letras do Centro de Ciências Humanas e Naturais, Universidade Federal do Espírito Santo, Vitória, 2017.

DEL PRIORE, Mary. Ao sul do corpo: condição feminina, maternidades e mentalidades no Brasil Colônia. 294 f. Tese (Doutorado em História) - Universidade de São Paulo, São Paulo, 1990.

DEL PRIORE, Mary (Org.). História das mulheres no Brasil. 10. ed. São Paulo: Contexto, 2017.

DEL PRIORE, Mary. Magia e medicina na colônia: o corpo feminino. In: História das mulheres no Brasil. 10. ed. São Paulo: Contexto, 2017, p. 78-113.

DIÁRIO SOBRE UM hospital psiquiátrico. Jornal do Brasil, Rio de Janeiro, $1^{\circ}$ Caderno, 16/2/1960. Disponível em: 
http://memoria.bn.br/DocReader/docreader.aspx?bib=030015_08\&pasta=ano\%20196\&pesq= hospital\%20psiqui\%C3\%A1trico\&pagfis=1768. Acesso em: 11 jun. 2020.

EAGLETON, Terry. Teoria da literatura: uma introdução. Tradução Waltensir Dutra. São Paulo: Martins Fontes, 1997.

ELIOT, T. S. Tradição e talento individual. In: Ensaios. Tradução Ivan Junqueira. São Paulo: Art, 1989. p. 37-48.

FAEDRICH, Anna Martins. Autoficção: um percurso teórico. Criação \& Crítica, n. 17, p. 30 46. dez. 2016. Disponível em: https://revistas.usp.br/criacaoecritica. Acesso em: 28 out. 2019.

FAEDRICH, Anna Martins. Os perfis da literatura de introspecção: o diário em Virgílio Ferreira e a autoria na autoficção. Revista Desassossego. São Paulo, n. 9, p. 125-139, jun. 2013. Disponível em: https://www.revistas.usp.br/desassossego/article/view/59410. Acesso em: 10 fev. 2019.

FERNANDES, Mariana Patrício. Vida surgida rápida, logo apagada - extinta: a criação de estratégias de fuga do hospício na escrita de Maura Lopes Cançado. 125f. Dissertação (Mestrado em Letras) - Pontifícia Universidade Católica do Rio de Janeiro, Rio de Janeiro, 2008.

FIGUEIREDO, Eurídice. Mulheres ao espelho: autobiografia, ficção, autoficção. Rio de Janeiro: UERJ, 2013.

FIORIN, José Luiz. O phátos do enunciatário. In: discursivos. São Paulo: Contexto, 2008, p. 153-162. . Em busca do sentido: estudos

FOUCAULT, Michel. A escrita de si. In: . O que é um autor? Lisboa: Passagens, 1992. p. 129-160.

FOUCAULT, Michel. A microfísica do poder. Tradução Roberto Machado. Rio de Janeiro: Graal, 2010 [1979].

FOUCAULT, Michel. História da loucura: na Idade clássica. São Paulo: Perspectiva, 2009.

FOUCAULT, Michel. Vigiar e punir: nascimento da prisão. Tradução Raquel Ramalhete. Petrópolis: Vozes, 1999 [1987].

FREUD, Sigmund. Arte, literatura e os artistas. Tradução Ernani Chaves. Belo Horizonte: Autência, 2018.

GEERTZ, C. A interpretação das culturas. Rio de Janeiro: Livros Técnicos e Científicos Editora, 1989.

GEERTZ, Clifford. Obras e vidas: o antropólogo como autor. Tradução Vera Ribeiro. 3. ed. Rio de Janeiro: UFRJ, 2009.

GOMES, Angela de Castro (Org.). Escrita de si, escrita da história. In: escrita da história: a título de prólogo. Rio de Janeiro: FGV, 2004. p. 7-24. Escrita de si, 
GOMES, Leísa Ferreira Amaral. Loucura e gênero: uma análise da escrita autobiográfica de Maura Lopes Cançado. 156f. Dissertação (Mestrado em Psicologia) - Universidade Federal de Minas Gerais, Belo Horizonte, 2014.

HALBWACHS, Maurice. A memória coletiva. Tradução Laurent León Shafter. São Paulo: Vértice, 1990.

HALBWACHS, Maurice. A memória coletiva. Tradução Beatriz Sidou. São Paulo: Centauro, 2003.

HERMAN, Hesse. O lobo da estepe. Tradução e prefácio de Ivo Barroso. 5.ed. Rio de Janeiro: BestBolso, 2013.

HERVOT, Brigitte; SAVIETTO, Maria do Carmo. A escrita autobiográfica. In: CARLOS, Ana Maria; ESTEVES, Antonio Roberto (orgs.). Narrativas do eu: memórias através da escrita. Bauru: Canal6, 2009. p. 23-36.

LEJEUNE, Philippe. O pacto autobiográfico: de Rousseau à internet. Tradução Jovita Gertheim Noronha e Maria Inês Coimbra Guedes. Belo Horizonte: UFMG, 2008.

LEMINSKI, Paulo. Ensaios e anseios crípticos. 2. ed. Campinas: Unicamp, 2012.

MACHADO, Jacqueline Simone de Almeida; CALEIRO, Regina Célia Lima. Loucura feminina: doença ou transgressão social? Revista desenvolvimento social. Montes Claro, v. 1, n. 1, p.1-8, jan./jun. 2008. Disponível em:

https://www.periodicos.unimontes.br/index.php/rds/article/view/1393. Acesso em: 12 abr 2019.

MACIEL, Sheila Dias. A literatura e os gêneros confessionais. In: ; et al. Em diálogo: estudos literários e linguísticos. Campo Grande: UFMS, 2004.

MEIRELES, Maurício. Perfil biográfico. In: . CANÇADO, Maura Lopes. Hospício é deus: diário I. 5. ed. Belo Horizonte: Autêntica, 2016a, p. 203-227.

MIOTTI, Charlene Martins. Ridentem dicere vervm: o humor retórico de Quintiliano e seu diálogo com Cícero, Catulo e Horácio. 215 f. Tese (Doutorado em Linguística, área de Letras Clássicas) - Universidade Estadual de Campinas. Campinas, 2010.

MUSILLI, Celia. Literatura e loucura: a transcendência pela palavra. 186f. Dissertação (Mestrado em Teoria e História Literária) - Instituto de Estudos da Linguagem, Universidade Estadual de Campinas, Campinas, 2014.

NEVES. Caroline Resende. Virginia Woolf e o espaço autobiográfico em Os Anos. 118f. Dissertação (Mestrado em Letras) - Universidade Federal de Juiz de Fora, Juiz de Fora, 2018.

NIKODIMOV, Marie-Gaille. Observar, compreender, participar. In: O livro da hospitalidade: acolhida do estrangeiro na história e nas culturas. berlicht. São Paulo: Senac, 2011, p. 83-96. 
OLIVEIRA, Allan de Paula. Antropologia: questões, conceitos e histórias. Curitiba: Intersaberes, 2018.

OLMI, Alba. Memória e memórias: dimensões e perspectivas da literatura memorialista. Santa Cruz do Sul: UNISC, 2006.

PENA, Felipe. Teoria do jornalismo. São Paulo: Contexto, 2005.

PESSOA, Fernando. Mensagem. Rio de Janeiro: Aguilar, 1976.

PESSOTTI, Isaías. A Loucura e as Épocas. São Paulo: 34, 1994.

PINSKY, Carla Bassanezi. Mulheres dos Anos Dourados. In: no Brasil. 10. ed. São Paulo: Contexto, 2017, p. 607-639. História das mulheres

PLAZA, Monique. A escrita e a loucura. Tradução M. F. Gonçalves de Azevedo. Lisboa: Estampa, 1990.

QUEIROZ, Maria José de. A literatura alucinada: do êxtase das drogas à vertigem da loucura. Rio de Janeiro: Atheneu Cultura, 1990.

REIS, Carlos, LOPES, Ana Cristina M.. Dicionário de Teoria da Narrativa. São Paulo: Ática, 1988.

SALLES, Anna Flávia Dias. Retratos em abismo: poses e posses do diário de Maura Lopes Cançado. 106f. Dissertação (Mestrado em Teoria da Literatura e Literatura Comparada) Universidade Federal de Minas Gerais, Belo Horizonte, 2017.

SCARAMELLA, Maria Luisa. Narrativas e sobreposições: notas sobre Maura Lopes Cançado. 269 f. Tese (Doutorado em Ciências sociais) - Instituto de Filosofia e Ciências Humanas, Universidade Estadual de Campinas. Campinas, 2010.

SCHECHNER, Richard. O que é performance? Programa de Pós-Graduação interdisciplinar em performances culturais. Tradução R.L. Almeida, abr. 2011. p. 1-25. Disponível em: http://www.performancesculturais.emac.ufg.br/up/378/o/O_QUE_EH_PERF_SCHECHNER. pdf. Acesso em: 30 ago. 2018.

SHOWALTER, Elaine. The Female Malady: women, madness, and english culture, 18301980. New York: Penguin, 1987.

SILVA, Gislene Maria Barral Lima Felipe da. Olhando sobre o muro: representações de loucos na literatura brasileira contemporânea. 219f. Tese (Doutorado em Literatura e Práticas Sociais) - Instituto de Letras, Universidade de Brasília, Brasília, 2008.

SILVA, Rosângela Lopes da. A sofredora do ver e a urgência da escrita: a poética de Maura Lopes Cançado. 132f. Dissertação (Mestrado em Teoria Literária e Literaturas) Universidade de Brasília, Brasília, 2017. 
SOUZA, Eneida Maria. Saberes narrativos. Scripta, Belo Horizonte. v. 7, n. 14, p. 56-66, jan./jun. 2004. Disponível em:

http://periodicos.pucminas.br/index.php/scripta/article/view/12542. Acesso em: 24 abr. 2019.

SOUZA, Vânia Romão de. Maura? louca? não, "cançada": os desatinos de uma existenciais de uma "hipermulher" nas décadas de 1940/1950. 182f. Dissertação (Mestrado em Psicologia Clínica e Cultura) - Instituto de Psicologia, Universidade de Brasília, 2014.

TEIXEIRA, Ivan. New criticism. Cult, São Paulo, set. 1998. Disponível em: http://www.usp.br/cje/depaula/wp-content/uploads/2017/03/New-Criticism_Ivan-Teixeira1.pdf. Acesso em: 27 de jun. 2019.

VASCONCELLOS, Paulo Sérgio de. Persona poética e autor empírico na poesia amorosa latina. São Paulo: Unifesp, 2016.

ZAGURY, Eliane. A escrita do eu. Rio de Janeiro: Civilização Brasileira, Brasília: INL, 1982. 